

$$
75 / 24
$$


1

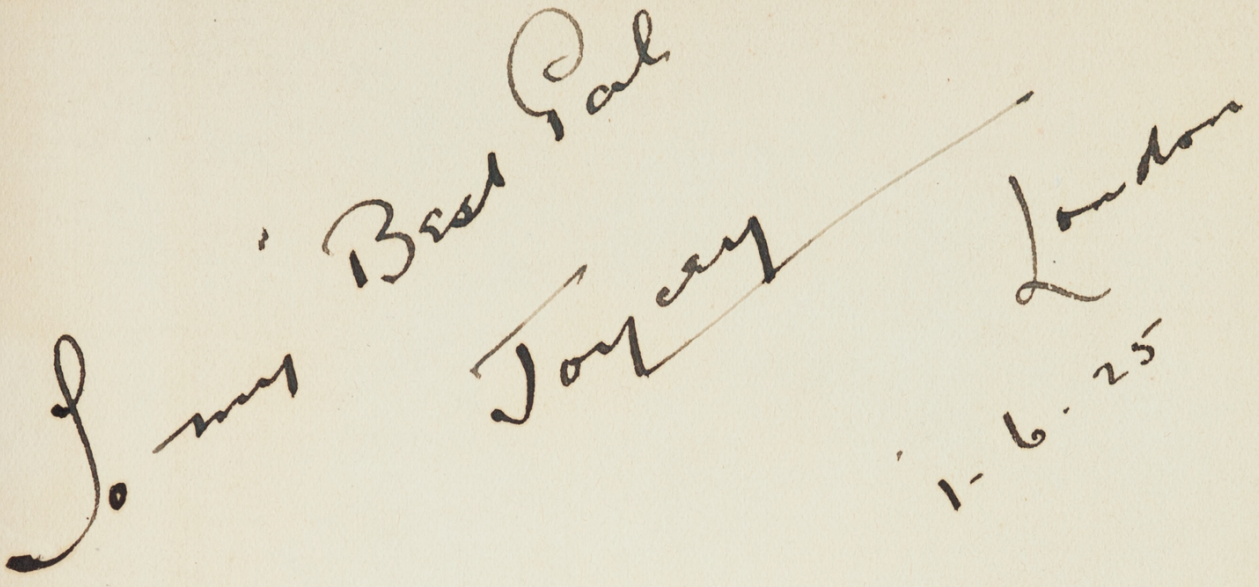

MUSEUM OF VICTORIA

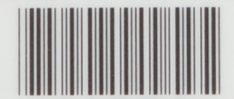

14994 

ANTARCTIC DAYS 



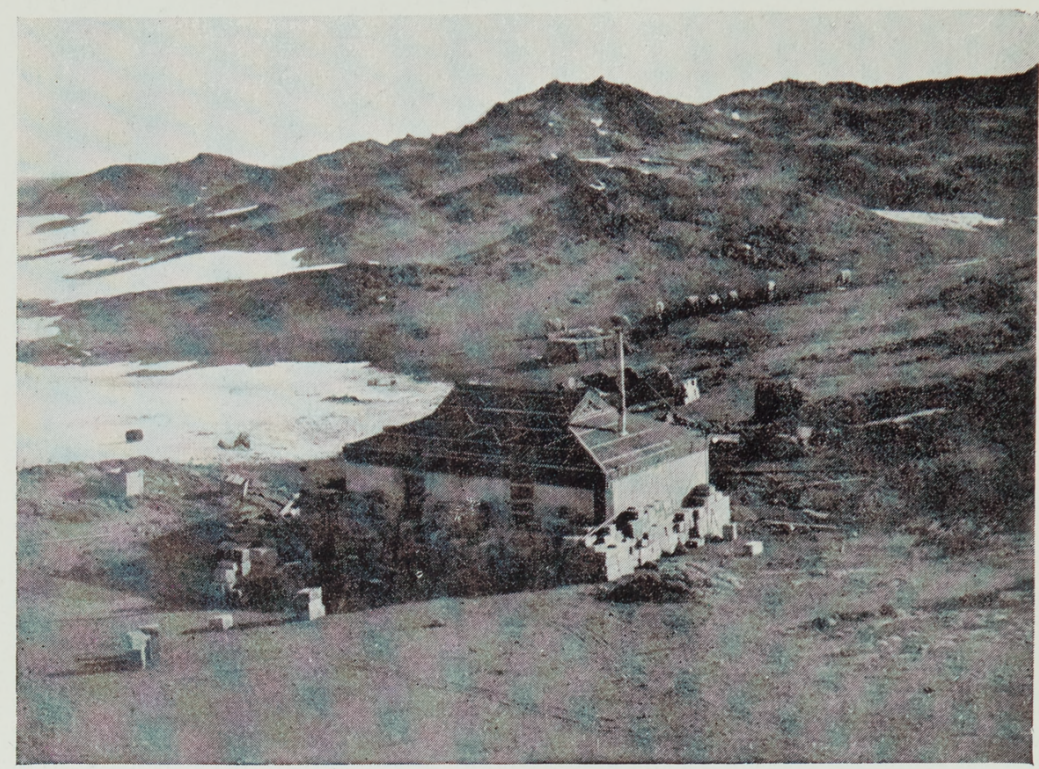

The Antarctic Land.

Our home in Summer.

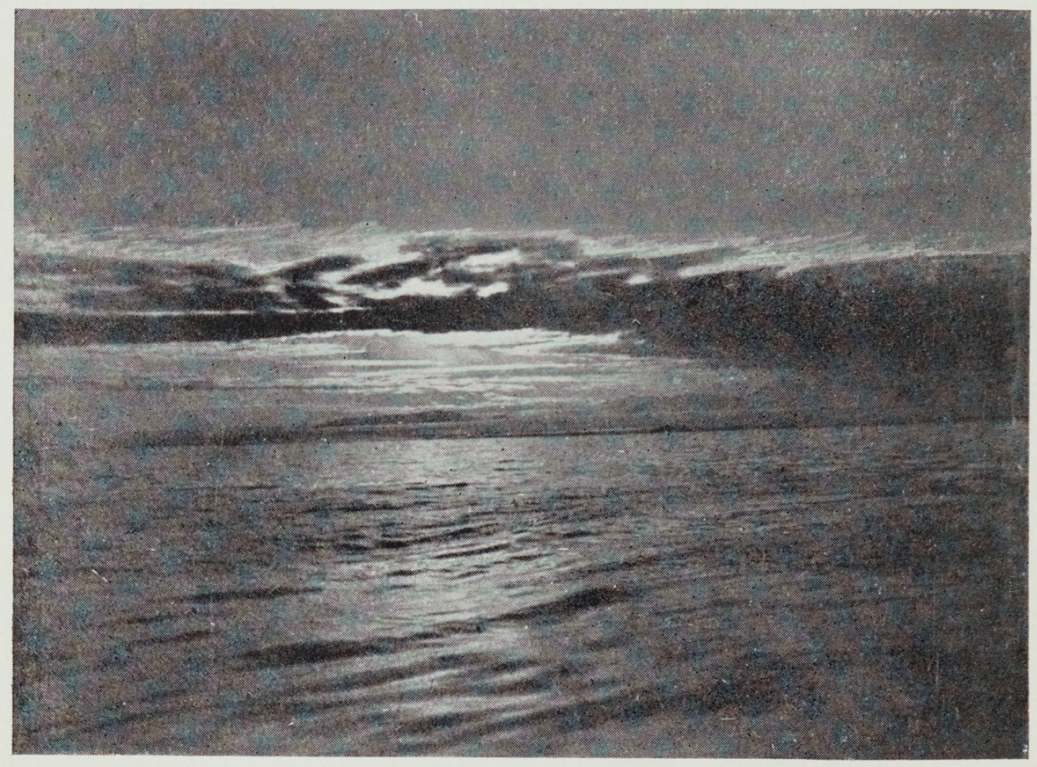

A Peaceful Night. 


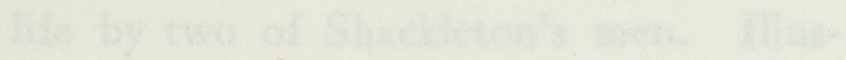

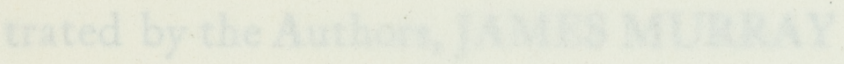

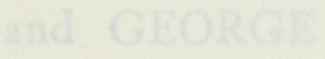

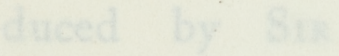





\section{ANTARCTIC DAYS}

Sketches of the homely side of Polar life by two of Shackleton's men. Illustrated by the Authors, JAMES MURRAY and GEORGE MARSTON, and introduced by Sir Ernest Shackleton

\section{LONDON : ANDREW MELROSE}

3, YORK STREET, COVENT GARDEN, W.C.

$$
1913
$$





\section{CONTENTS}

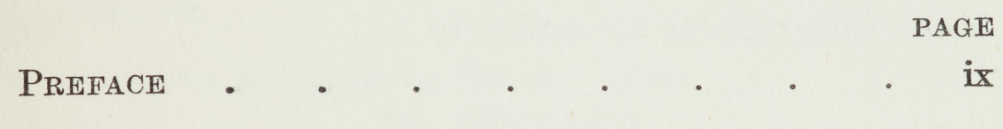

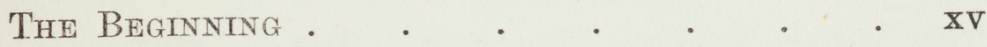

CHAPTER I

The OUTward Voyage $\quad$ - $\quad$. 1

CHAPTER II

The ShiP's Magazine . $\quad$. $\quad$ - $\quad$ - $\quad$ - 11

CHAPTER III

A Naturalist on the OCEaN $\quad$. $\quad . \quad$. $\quad 28$

CHAPTER IV

Yarns OF THE VoYaGE . . . . . 47

CHAPTER V

Jack Ashore: Ports of Call and Between the VOYAGES

CHAPTER VI

The Voyage to The SodthWARd . . . 71 


\section{CONTENTS}

PAGE

CHAPTER VII

The Antarctic . $\quad . \quad . \quad . \quad . \quad . \quad$. 79

CHAPTER VIII

First Impressions of Sledging • • . 86

CHAPTER IX

The Shore Party's Magazine: The "Aurora Australis " . . . . . . . . 103

CHAPTER $\mathrm{X}$

Animal Life: Penguins, Seals, etc. . . . 127

CHAPTER XI

YARNS OF THE SOUTH . $\quad . \quad . \quad . \quad . \quad 142$

CHAPTER XII

Last Days in the South . . . . . 161

CHAPTER XIII

The Return to Civilization . . . . 171

CHAPTER XIV

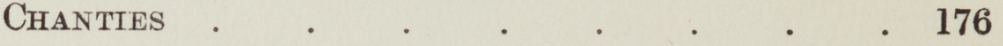

vi 


\section{LIST OF FULL-PAGE ILLUSTRATIONS}

Facing
Page

Frontispiece

The Authors at Home in the Antarctic . . xv

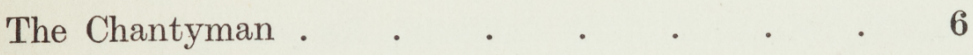

Keep off the Paint . . . . . . 10

Strange Things which we see in the Sea . . 29

Studying under Difficulties . . . . . 32

Birds . . . . . . . . . 40

The Biologist . . . . . . . 44

"Come on Board, Sir" . . . . . . 52

A Meeting in Mid Ocean . . . . . 56

An Inhospitable Coast. . . . . . 79

An Antarctic Landscape . . . . $\quad$. 80

The Antarctic Land. A Peaceful Night . . 82

A Curious Photograph . . . . . . . 84

Fourteen Good Men and True . . . . 104

An Interview with an Emperor . . . . 109

A Pony Watch . . . . . . . 117

The Messman . . . . . . . 121

"Good Morning!" . . . . . . . 126

vii 


\section{LIST OF FULL-PAGE ILLUSTRATIONS}

Seal Life-

Hulloa! Not so Bad as it seems . . 128

A Mother. Unfamiliar with Danger . . 128

Penguin Life-

A Giant among Pigmies. Dignity and Impudence 130

The Snapper snapped. Penguin and Man making Friends. . . . . . 130

Feeding Time $. \quad . \quad . \quad . \quad . \quad . \quad . \quad 132$

Danger Near . $\quad$ • . . . 132

More Penguin Life-

This looks like a Squabble. "Please, let me have a turn . . . . . . . 134

"Whatever can be keeping Mother?" "Steady, Darling!" . . . . . . . 134 The Cruel Skua . . . . . . . . 136

Some of our Dogs . . . . . . . 136

The Killer Whale . . . . . . 138

Old Scamp . . . . . . . . 138

The Clean Shirt . . . . . . . 142

Mac eats the Skipper's Jam Tart. . . . 144

Mac made Himself a Pair of Trousers . . 146

"A Long Dark Day" . . . . . . 158

Almost a Tragedy $\quad . \quad . \quad . \quad . \quad . \quad .166$

Just back from the South Pole . . . . 171

Back to a Green Earth . . . . . 172

viii 


\section{PREFACE}

\section{BY SIR ERNEST SHACKLETON}

T TE are all familiar with books of Polar Exploration. We know the story of the long marches, the blizzard days, and the hungry days. We have lived with the explorer through the long Polar night, the voyage through the ice, the building of the huts, the organization for the sledging, and finally the long march towards the goal of their desire.

But these are the official accounts, necessarily long and complete, as must be the record of important work. For the first time an unofficial, and therefore more human document, is presented to the public. The little incidents that go to make up the sum of the day's work, the humour and the weariness, the inside view of men on an expedition, is in the following pages faithfully depicted.

One great point of interest in the book, to my mind, is that it is written and illustrated by two members of the Expedition, who both have what is called the saving grace of humour. If there is occasionally a dig at any one, at any little idiosyncracy, I hope that that member, and the public, will view it in a friendly light, in the same way that I view the tales told 


\section{PREFACE}

against myself. One should take it as a compliment that one's personality is of enough interest to be recorded. All Polar explorers are optimists with vivid imaginations, and optimists with vivid imaginations lay themselves open to criticism not to be expected or deserved of by those who are "ta'en in earth's paddock as her prize."

I would advise any one who wants to get to the kernel of the life of the Polar explorer to read the book to which I have not only the honour, but pleasure, to write this little preface. If $I$ had been asked to contribute to the book I certainly would have tried, as the Americans say, to "get my own back" on the authors, who were my acquaintances in 1907, and who, in 1913-I hope they will agree with me-are my friends.

It is a curious thing that one of the authors is a scientific man and is capable of counting the minute hairs on the leg of a spider, and yet with equal facility can see the broad lines of life. The other is not a scientific man, but, as an artist, depicts what he sees with the same faithfulness as the man who glues his eye to the microscope.

Why I say Marston is not a scientific man, and I am now going to take advantage of the Preface, is because of the following story.

On our Expedition we had a learned Professor and Geologist, who has undoubtedly a reputation for extreme politeness. Marston met the Professor one day, laden down with specimens of rock in a bag. Said Marston to the Professor, "Can I carry your bag ?" "Oh, don't trouble, Marston, really it is 
too good of you"; but somehow or other the 50-1b. bag was transferred to Marston's broad and willing shoulders. Instead of being content with the haul of rocks, the Professor began picking up more of the débris scattered along the mountain side, and the 50-lb. bag soon became $60 \mathrm{lbs}$. Marston thought he had had about enough of it, so every time that the Professor knelt down to coax rock out of its surrounding ice I saw Marston discharging from the bag a rock of similar size and weight. The Professor arrived at the hut fondly imagining that he had got everything he had worked for, and received with profuse thanks the bag from Marston. For this reason $I$ say that Marston is not a scientific man.

And this story of the rocks reminds me of another story of something which happened in the North of Canada. A Government geologist, with infinite labour, had collected in a region far beyond civilization some very interesting geological illustrations. Most of the collecting was done on the barren ground 280 miles north-east of the Great Bear Lake. First the scientific man and the porters of the party carried the rocks on their backs to the Great Bear Lake, paddled it 300 miles across the lake, and alternately paddled and portaged it 1,500 miles up the Mackenzie, Slave and Athabasca Rivers. The last portage was a half-mile one at the Grand Rapids up the Athabasca, and it was being done by Indian employees of the Hudson Bay Company. These Indians are ingenious men, and they still tell with pride how they saved much labour by emptying all the heavy bags and boxes at the lower end of the 


\section{PREFACE}

Rapids and filling them again at the upper end with rocks of similar weight, thus saving half a mile of difficult carrying. The substitution was found out a year later in Ottawa.

I am afraid that I am taking advantage of my space as the writer of a Preface, but I cannot resist telling another story of the Professor's politeness. It was an early spring journey in the Antarctic, temperature $50^{\circ}$ below zero, the Professor, another man and myself were on the journey. After shivering for a considerable period I dropped into what I call the uneasy "spring sledging sleep." I got a dig in the ribs, and I heard this : "Excuse me, sir, if it is not giving you too much trouble, and you really don't mind, would you oblige me by telling me what the time is ?" But even this politeness pales before an episode that occurred on the great inland plateau of the Antarctic.

The party had been marching over dangerously crevassed ground, where there were chasms and pitfalls at every step. The party had come to camp. The Professor went outside the tent, leaving Mawson inside. Suddenly Mawson heard a polite voice saying, "Mawson!" Mawson answered, "Hullo!" "Are you very busy, Mawson?" came the polite, distant voice. "Yes, I am ; what do you want?" came the gruff reply. "Really busy, Mawson?" quavered the reed-like notes. "What do you want?" replied Mawson. "Well, if you are not too busy, I am down a crevasse and I cannot hold on much longer." So much for Antarctic politeness. 


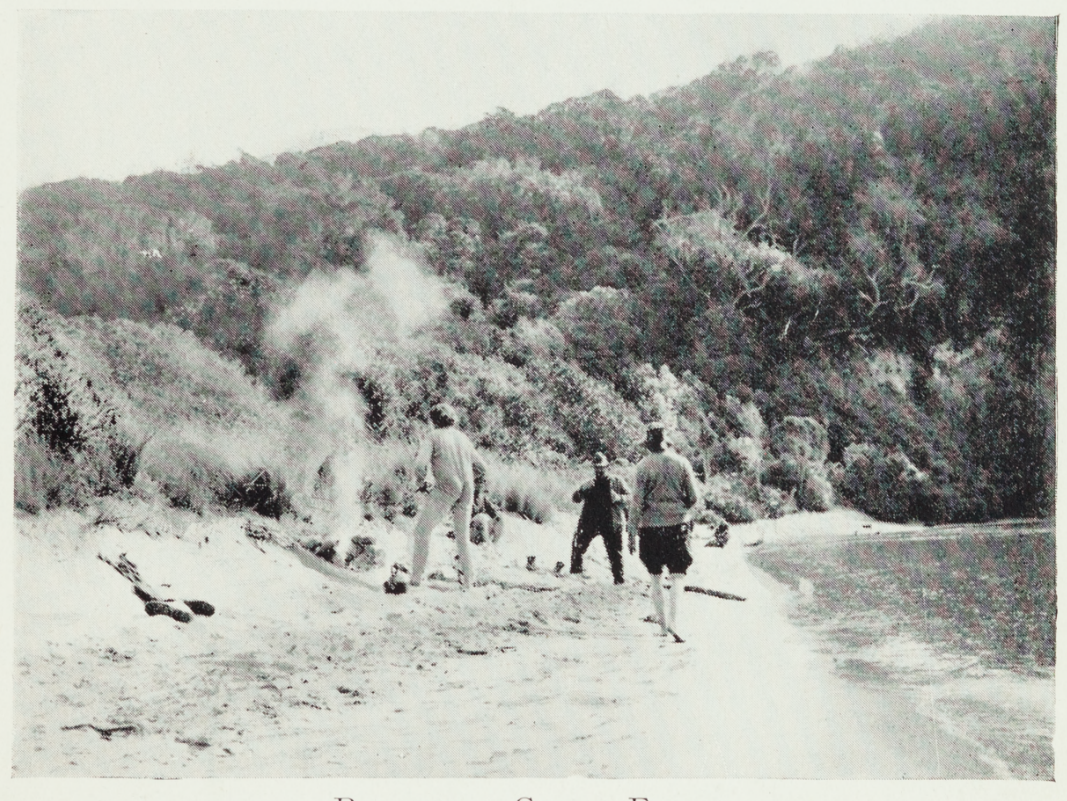

Back to a Green Earth.

A day of innocent abandon on Stewart Island. 

But when an explorer returns from the Antarctic, and is asked questions, he learns more about human nature than he ever learnt from this icy fastness.

There is one stock question which invariably comes up. "Was it very hot there?" and you answer, "No, it is the coldest place on earth." "Oh, really," replies the inquisitor, "I always thought that the further south you went towards the Equator the warmer it got." After one's first surprise one gets hardened and explains exactly why it is. But I have found, as a rule, that most questions are asked from a genuine desire for knowledge, and it is only natural that a person who is not a geographical explorer should be unacquainted with these faroff places, though sometimes there is no excuse for the remarks that are made. As nearly everybody knows, the penguin is a bird, and pemmican is a food, and when at the end of one of my lectures my chairman, making a few valedictory remarks, said, "We thank you so much for your lecture, Sir Ernest, we love to see the moving pictures with the dear little pemmicans running about," he was almost as bad as the old clergyman who, after I had given the lecture, which I must say I was rather pleased with, got up and said, "I thank you for your lecture; the photographs were lovely."

But one gets hardened to these things. Once having lectured at a very famous Public School, and receiving a good fee, I wrote to an equally famous rival Public School, suggesting that a fee of the same proportion would satisfy me if they liked to hear my lecture. The answer that I got was: "Dear Sir: xiii 


\section{PREFACE}

This is five times as much as we pay to even firstclass lecturers."

But I must stop these reminiscences, or instead of a Preface a volume will be the result, and I therefore just commend to the public in general this little book, and I wish it the circulation that I feel it deserves. 



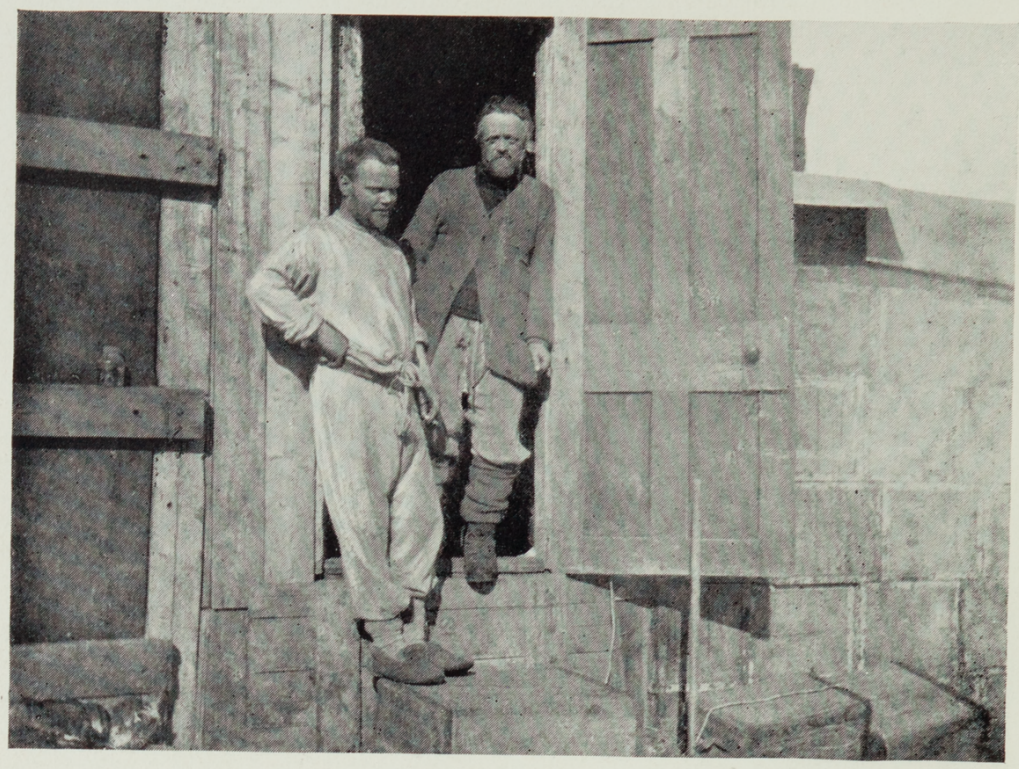

The Authors at Home in the Antarctic. 


\section{THE BEGINNING}

NOUGH-some might think more than enough-has been written in recent years about the Antarctic. The official narratives of all the expeditions might be supposed to leave almost nothing untold about life in the Polar Regions.

Yet the questions put to me by friends often indicate how far they are from having any comprehension of what the life is really like. This may be partly because so much of the homely detail, which alone can give a vivid impression of the life, must be omitted from the great books. It would be infra dig. in these works to notice too closely the humours, the pathos, the commonplace of life on an expedition.

The fact is that the funniest things about an expedition can never be told. You would hurt somebody's feelings.

People imagine that the Polar Regions are cold, that their coldness is the chief thing about them, the main disadvantage of living there. It is not so; it is not cold, not so very cold, or at any rate it very often needs the thermometer to tell you so. You do not worry about it, so long as you are in camp; you have a warm hut, you are clad for the 


\section{INTRODUCTION}

climate and fed for it. The cold is only an incident. It is a dry cold, so that in calm weather you do not notice it. In summer time you can go about clad only in pyjamas (with boots, mitts, and hat, of course). On occasion we have handled, with bare hands, the wet iron of the dredge just brought up out of the sea, for several minutes, without suffering any inconvenience, while the temperature stood at $80^{\circ}$ of frost (Fahrenheit).

When you go on a sledging journey, and are half starved and exhausted with hard work, it is different. Then you learn something about cold. But if you wish to hear about cold, hunger, frostbites, hardships of all sorts, you must ask Shackleton or some of his companions who went on big sledging journeys, especially spring-sledging. I have lived for over a year in the Antarctic, and I know nothing of cold or hunger there-thirst, yes! In short, life in the Antarctic has been described as a picnic, so long as you keep off sledging.

When I joined Shackleton's expedition I had only recently recovered from an extensive general breakdown in health, the consequence of prolonged exposure under trying conditions while engaged in surveying. I had had rheumatism, inflamed eyes, and God knows what not, a chill finally leading to the culmination of my woes in appendicitis, and I still caught cold on the slightest provocation.

I was eager enough to go to suppress all mention of these disabilities, salving my conscience by the reflection that it was the doctor's business to detect any unfitness, which he did not. Still I xvi 


\section{THE BEGINNING}

was just a little bit uneasy in my mind at foisting upon Shackleton such a wreck of humanity.

I therefore sought out two well-known Antarctic explorers, who had accompanied different expeditions, and, without giving myself away, put tentative questions to them. They were old familiar friends of mine.

The first assured me that it was just a picnic down South, that you could not be ill there if you tried; told me that So-and-so went down far gone in consumption, soon became one of the strongest, and before he had finished with the Antaretic had made a record for endurance on an extremely arduous journey.

The other used almost the same phrase, said it was simply a picnic, if you went down ill it cured you; there was no intermediate state between the two extremes of bouncing health and sudden death, by accident. "Scurvy, you say! Ah, of course; but then, nobody has any business to have scurvy."

Life in the Antarctic is not all picnic, but the term aptly enough describes life at the main camp with a crowd of good fellows.

I asked one of my friends for some information about the conditions of work. "Don't worry about work," he said. "That will take care of itself. Go and see the men you are to live with. That is the only important matter." That was sound advice.

So much for my joining the expedition. An account, if such were to be had, of the manner in which each of the men came to be connected with the Expedition would not be devoid of points $\mathrm{x}$ vii 


\section{INTRODUCTION}

of interest. Some few of these histories are known to me.

When a man has been through an expedition and is getting up another, the thing he naturally first thinks of is to send for some of his old men whom he has learned to trust. So our skipper sent for Cheetham, who had been with him on the Morning.

This story I have more or less at third hand, so it may be a bit out in detail, but I believe it is true in essentials. Cheetham had been asked to join at once. A telegram was received, ostensibly from him, refusing the offer; ten minutes later came another to tell that he was on his way to join the ship. The mystery was not cleared up until he arrived himself and explained that the first telegram was not sent by him, but by some busybody who thought he ought not to go. As soon as Cheetham got to know about it he soon put that right. It was not so easy to hold him back from an Antarctic Expedition.

Cheetham of course brought his old messmate Chips along, and the method of his enlistment was like this. Mr. Bilsby (Chippy) was at the time peacefully engaged in following his avocation as a carpenter upon some dwelling-houses of his native "Hool."

Cheetham went first to Mrs. Chippy and told her that Chippy was going with him on another Expedition to the Antarctic. He made it all right with her. Next he went to the house where Chips was working, and hailed him, when a dialogue in something like the following terms took place. 


\section{THE BEGINNING}

Cheetham: "Eh! Chippy lad, coom darn. Tha's barn t'ert Sarth Poal wi' me."

Chips: "I'se etter see t'missis furst."

Cheetham: "Ah've seen t'wife, Chippy, coom on."

And so it was settled.

It has been said that people will believe anything you like to tell them about the Antarctic, -except the truth! There is much truth in this assertion, but to claim that it is entirely correct would land us in a quandary. You might ask: "What of the things you are now telling us yourself ?" It is true to this extent-that human nature is so queerly constituted that when men have formed certain preconceptions of the conditions that prevail in out-of-the-way regions, they will have nothing else; icebergs and Polar bears in the frigid zones; wild beasts and exciting adventures with savages in the tropical forest.

It is hard to have to disappoint an anxious inquirer by the cold statement that there are no Polar bears in the Antarctic. Some people seem to take the statement as a personal affront, and I often doubt if they believe it. It is also hard to convince them that Antarctic icebergs, at least in the Ross Sea region which we know, are not as a rule in the least like the (pictures of) northern bergs, but are flat tables of compressed snow.

So strong is the obsession of preconceived notions that I believe artists have gone to the Antarctic, looked at the tabular bergs, and then drawn pinnacled bergs as portraits of them.

$$
\text { xix }
$$




\section{INTRODUCTION}

We offer you these pen and pencil sketches of our experiences on a Polar expedition. They are as true as we can make them, as little coloured by imagination as is compatible with human limitations, and the obscuring of memories after four or five years. We hope they will help towards giving a true picture of expedition life as it really is, or that they will at least amuse.

We tell some yarns against the other fellows, as well as against ourselves. They are all told in goodhumour, and it is hoped that nobody's feelings will be hurt. The Antarctic life is not calculated to foster too great a sensitiveness in the matter of stories told against you.

The writing, when necessary, is in the first person, and to avoid any more of that confounded mixing of persons, which is the plague of partly joint writings, let me explain that each chapter is written by one man. I do most of the writing; Marston does the best of the illustrations. Marston writes on the Chanties and Sea-songs, and on sledging.

In claiming indulgence for my imperfect sketches illustrating life on the voyage out, when Marston was not with us, let it be mercifully borne in mind that all of them were done on a rolling ship, some when she was rolling as much as 50 degrees.

From the scope of our subject it almost inevitably results that the work is scrappy; a series of clearcut sketches can scarcely be otherwise. The general narrative, in which all would find their places, having already been given to the world, the connective tissue of our sketches is of the slightest. 


\section{THE BEGINNING}

As far as possible the incidents are given consecutively, and the various stages of the Expedition kept distinct-the voyage, the Antarctic, the return.

From the familiar homely note we attempt to strike it might be inferred that we aim only at a collection of funny stories. But it is not so. We try to keep a just balance and show the sober as well as the laughing side of things.

JAMES MURRAY. 

THE OUTWARD VOYAGE

\section{CHAPTER I \\ THE OUTWARD VOYAGE}

T $N$ these days of luxurious travel on floating hotels few people enjoy the delights of

1 voyages on sailing vessels, when weeks or months are passed without sight of land or of other vessels. The expedition ships with their "auxiliary steam" are essentially sailing vessels, and still provide such delights to those who are privileged to travel in them.

Most of the people deny themselves these pleasures, and, having had some, I do not blame them.

Whoever has not experienced it will find it difficult to imagine the wild excitements of such a voyage. Some might imagine life to be monotonous on board a small vessel, capable of sailing or steaming about five knots, or by combining both methods of propulsion, with the assistance of a gale of wind and a favouring current, may attain to eight knots ; voyaging for weeks out of sight of land in unfrequented regions. But the life is not monotonous to a philosophic mind, if only it be philosophic enough. It is not monotonous; once a month or even oftener, the officer on duty may call your attention to a passing vessel, hull down, it is true, but distinctly 


\section{MEMORIES OF ANTARCTIC DAYS}

visible through a powerful telescope; a gull or an albatross may come along and follow the vessel for a while, or several of them may even come together ; a flying fish may come on board, and whole shoals of them will be disturbed at once, and will patter into the sea like raindrops; you are allowed to shift cargo, to labour for hours in the search for a box which all the time is lying in the mate's cabin ; if you are good you may be allowed to paint ship.

You can lie out on the bowsprit under the broiling sun for hour after hour, fishing for bonito with a bit of white cloth dangling from the end of a line. You never catch a bonito, probably no one has ever caught a bonito in that manner, but what is that to a true fisher? It is the traditional method of fishing, and sailors always teach it to greenhorns.

Then there is always something happening. Every day the sun rises and sets; every day you sail through a new bit of ocean, only they are all so much alike you would never know.

We had work to do; we had amusements, at least we tried to amuse ourselves. Our fun and jokes will very likely impress the reader as elephantine. Little isolated communities develop and elaborate jokes which are so entirely dependent for their quality on local conditions or personal characteristics that other people fail to see them. We have tried to avoid boring the reader with these local pointless jokes by submitting anything we thought of writing to independent criticism. If we have let any such slip in, pray forgive us and skip them.

One very real advantage of a long, slow voyage 

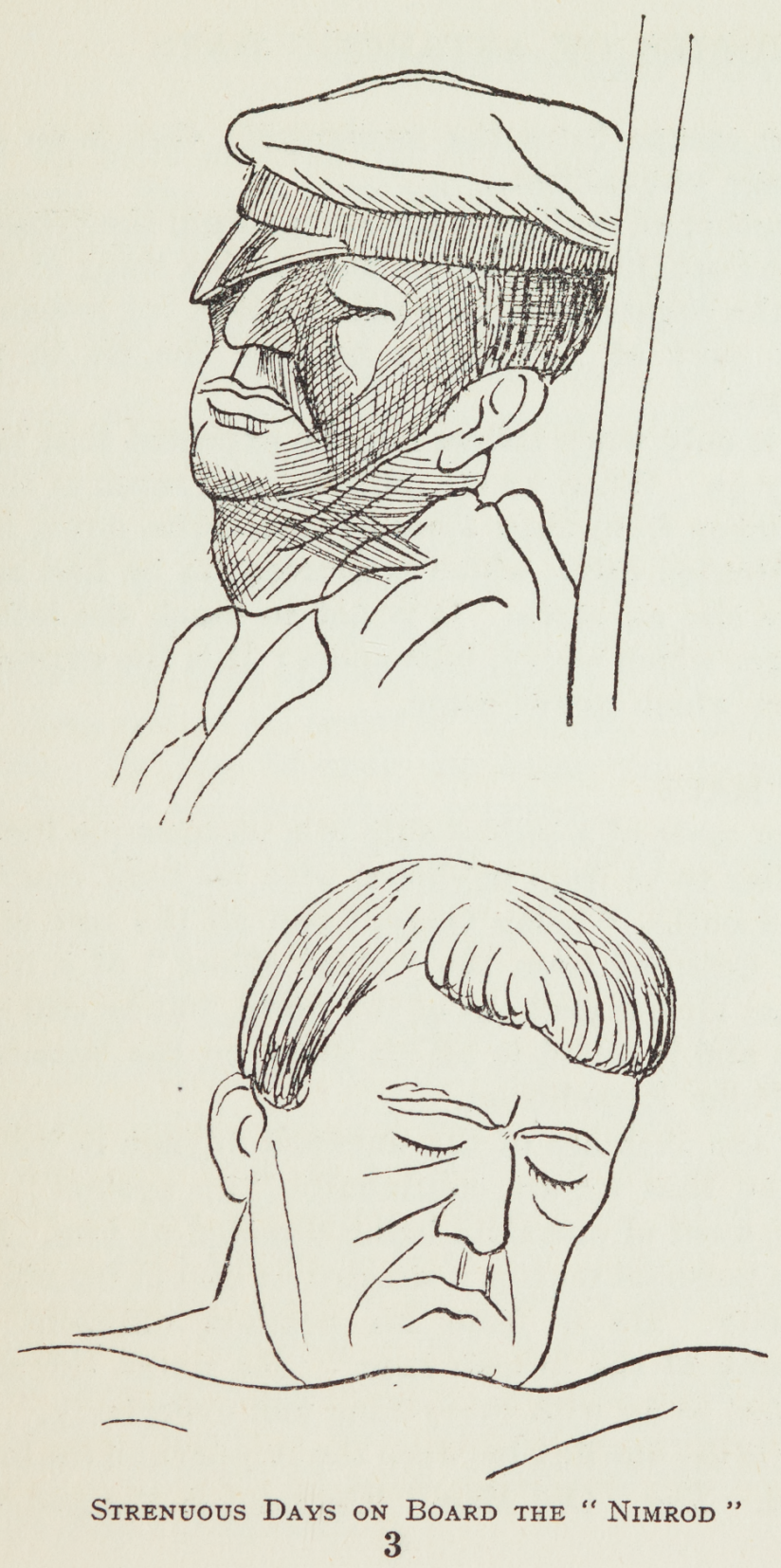


\section{MEMORIES OF ANTARCTIC DAYS}

is the escape from the newspaper; that is an advantage unqualified.

Another advantage is the escape from the tyranny of the Post Office. It is an unorthodox thing to say, and the eagerness with which we look for letters at every port of call seems to give the lie to the statement.

It is only when letters may be expected that they worry us. When we are quite beyond reach of them we escape from their tyranny and settle down into a contented calm, which is scarcely to be had anywhere else on earth. It is not so much the letters you get which worry, bills apart; it is the expected letters which never come.

\section{THE MATE}

The mate of a sailing ship is a picturesque figure, familiar to us from boyhood, with his bluff manner, round oaths, "belay there," and all the rest of it. How different from the "chief officer" of a liner. He has almost died out of the world, but he still survives and is found in all his glory on the vessels of the Polar Expeditions.

In the sketches of the outward voyage it will be noticed that we are continually "up against" the mate, most of our skits being directed at him. It is not a personal matter; we gird at him in his official capacity. He is from his position officially the " enemy of the human race." He works the ship, and has to do with everything and everybody.

He is the one link between the skipper and the lower world. The "Old Man" (Captain) is the god who 


\section{THE OUTWARD VOYAGE}

sits up aloft and has no cognizance of mundane matters. The awe with which the old man is regarded does not in the slightest degree extend to the mate. He has to see to it that, following the old sailing ship tradition, everybody on board under the rank of mate is made as miserable as circumstances will permit. He has come through it all himself, and you are not going to get off.

Whenever possible he has to contrive that the vessel must tack, or sail be made or taken in, just after the watch has turned in below. He has to see to it that the passengers (the scientists) do not become enervated through luxurious living by calling them out at all hours of the night to assist the watch. He has to rack his brain for means of still further reducing their privileges.

All these little offices make the mate extremely popular, but there is one thing which tends to keep everything sweet, and prevents wounded feelings from rankling. You can get one back at him. The sailors can do it in their chanties. So long as there is no insubordination or back-talk, it would be beneath his dignity for the mate to affect to notice any hint conveyed in a chanty, or go with complaints to the old man. So he must have some uncomfortable moments, as he has to stand by and listen while some hints of his personal shortcomings are delicately conveyed to him in song.

The passengers got some of our own back in the form of caricatures or skits, sometimes pinned to the mast in the wardroom table, sometimes contributed to the ship's Magazine. 


\section{MEMORIES OF ANTARCTIC DAYS}

Outside his official capacity, we respected and liked our enthusiastic mate. Nobody had the honour and prestige of the Expedition more at heart than he, or was more ready to expend his utmost effort to further it.

\section{CHANTIES}

Life on the Nimrod was ameliorated by the sailors' chanties. The chanty is a fine old institution for promoting work with a will. There used to be chanties appropriate to every operation aboard a sailing vessel; nowadays we do not discriminate too minutely.

Mackay had good store of chanties, so had the bo'sn, Cheetham, and old Daddy Spice.

Now Daddy Spice was inclined to choose chanties which had the longest verses and shortest choruses (of course you only work with the chorus). A mate reared on the tradition of the old school of windjammers does not relish anything which gives the sailor an easy time, and it was a sight to watch the face of ours as we drawled through the slow length of the verse, followed by two quick bars of chorus (=two pulls). But chanties also were part of the tradition and he could not interfere.

It is amusing to join in a chanty when Cheetham is chantyman. When we are all in place and ready to pull, Cheetham opens his mouth to start the chanty, his face beaming with delight (just as in the accompanying photo). But no sound comes. It is an awkward moment for those who do not know Cheetham. Sometimes they begin hauling 


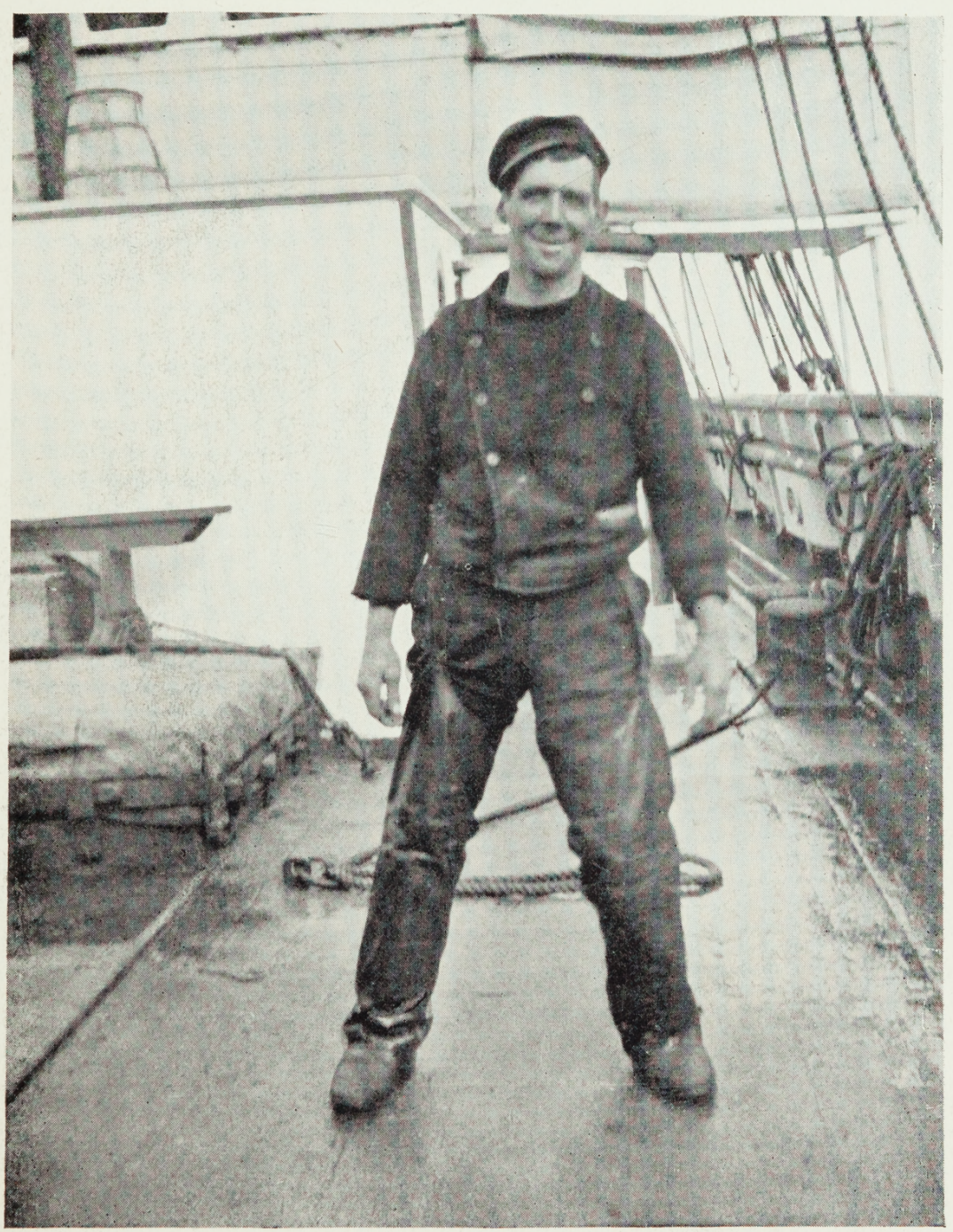

Photo by Sir Philip Brocklehurst.

The Chantyman.

Alf. Cheetham, who was also the bos'n and one of the best of comrades. 



\section{THE OUTWARD VOYAGE}

without a chanty, and on one occasion, quite unconscious of offence, a man started another chanty.

Still Cheetham stands with open mouth and a look of ecstasy, a finger uplifted to show that it is all right. At length a faint, squeaky noise comes

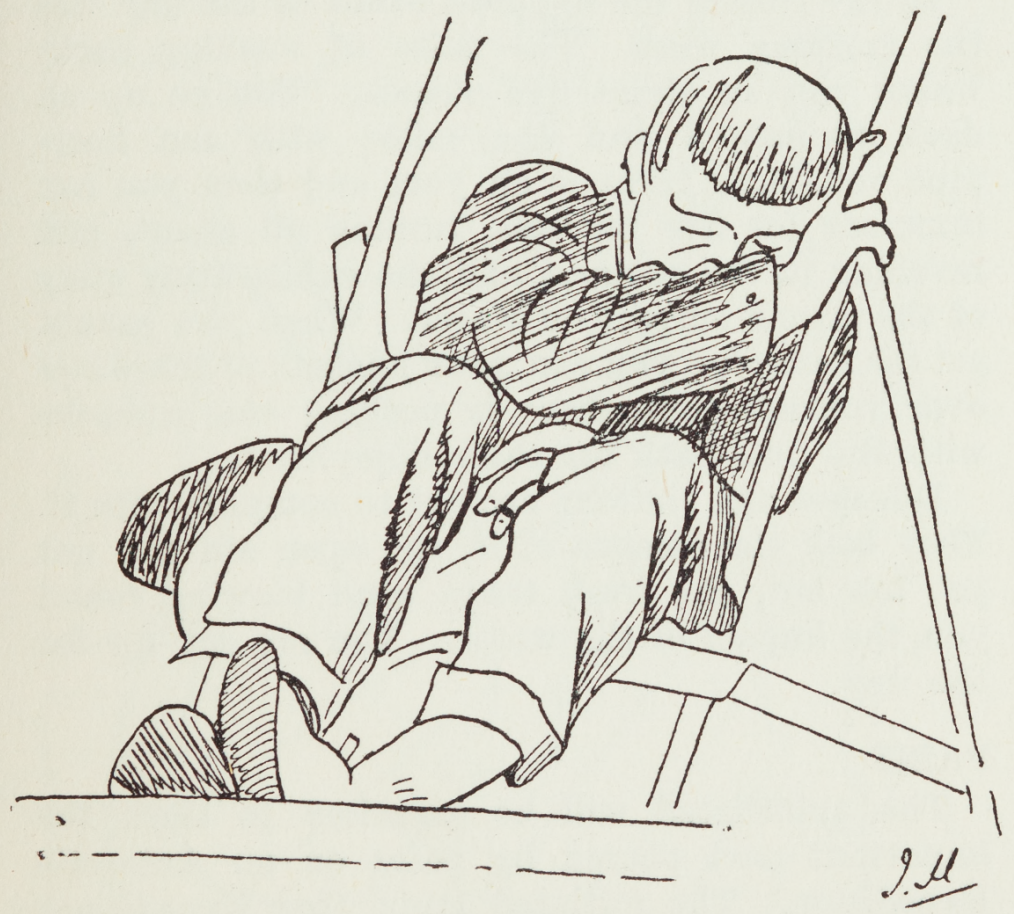

AMUSEMENTS.

This sketch will serve to show that on the long voyage we were not entirely without amusements, although, under the conditions, these were limited in range.

out, it has been all this time welling up from some remote depths of his interior. It gathers strength and at length issues as the full volume of "A yankee ship came down the riv-er." Cheetham's look 


\section{MEMORIES OF ANTARCTIC DAYS}

changes to one of triumph; he knew it was coming all right all the time.

But Marston is going to write all about Chanties.

\section{THE MORNING BATH}

In the tropics the happiest event of the day was the morning wash. The noise of washing decks wakes you up about five o'clock. You go up on deck au naturel and the sailor with the hosepipe obligingly turns it on you, and then you can luxuriate for five minutes, turning all about, and revelling in the coolness and the exhilarating sting of the strong current of water. When you cannot get the hose-pipe you can pour buckets of sea-water over yourself, but there is nothing can compare with the hose-bath for sheer enjoyment.

Douches and showers are not to compare with it. They lack the essence of it, the open air, sun not yet too hot, the fresh trade wind blowing round you, the impact of the water. You are set up for the day.

\section{PAINT}

The uninitiated will be surprised to learn the important part played by paint on an Antarctic Expedition. The initiated know that Expeditions are undertaken chiefly with the object of getting old ships thoroughly painted. Expert scientists are carried for the purpose.

Such, at any rate, was the view of our good, honest, enthusiastic, almost too enthusiastic, mate.

However engrossed they were in their special 8 


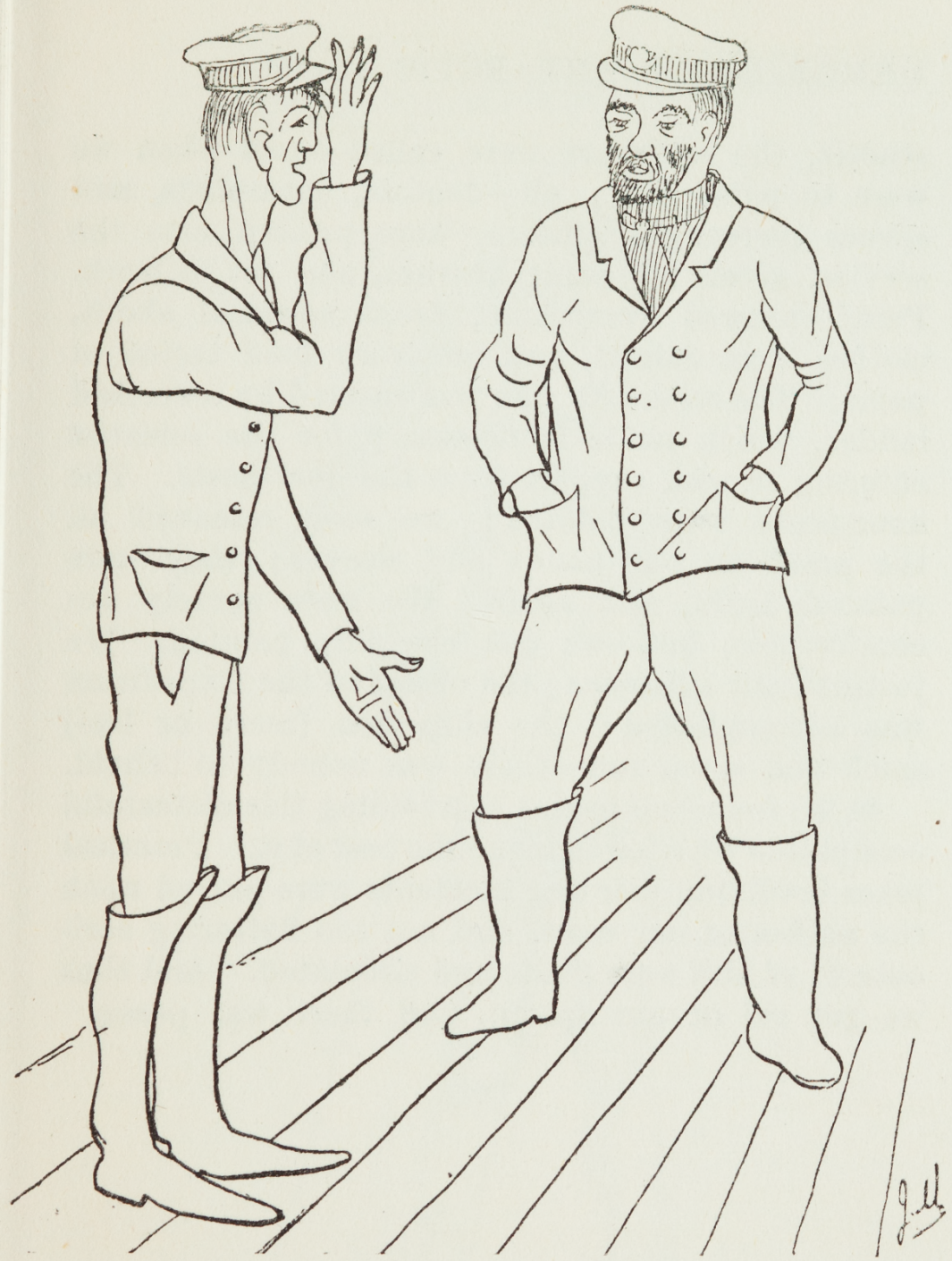

MATE : "Please, sir, mutiny in the ward-room, sir."

Captain : "What!!!"

Mate : "It's one o' them Scientists, sir, refuses to paint. Says he wants to do scientific work."

CAPTAIN : "Scientific work, indeed; refuses to paint! Put him in irons at once. What does he think an Expedition is got up for ?" 


\section{MEMORIES OF ANTARCTIC DAYS}

studies, the scientists were called upon when we were to paint ship; all-doctors, naturalists, and spruce mercantile officers-were pressed into the service, given big paint brushes, and set to work. Paint smeared everything, drops splashed about, clothes were ruined, and our very food tasted of paint. The scientists' den was entered by a vertical ladder, which made it necessary for the scientist entering to seek support from the door-posts. The door-posts were painted; we soon removed all the paint on our hands and sleeves; they were painted again, and again. We were acutely uncomfortable, but-we got the ship painted. We justified our existence ; the object of the Expedition was accomplished; the ship was (more or less) spick and span, and-there was nobody to behold.

As we found no means of avoiding this distasteful occupation we tried to make the best of it. Practical jokes involving painting incidents were played upon the author of our woes, and not too flattering caricatures of him were made and circulated. And thus we got rid of our spleen, and there was peace. 


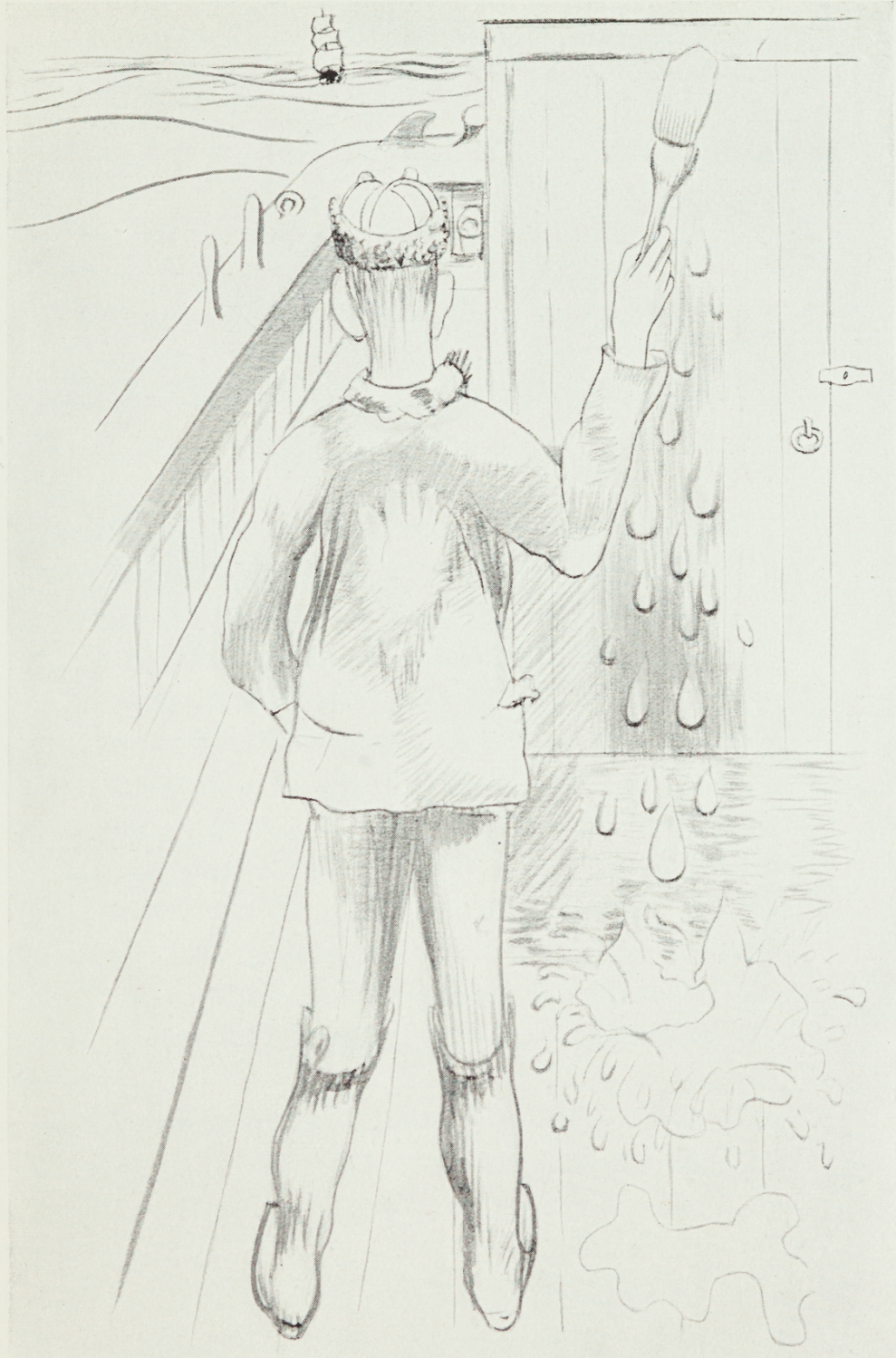

Sketch by J. Murray.

Keep off the Paint. 



\section{THE SHIP'S MAGAZINE}

\section{CHAPTER II}

\section{THE SHIP'S MAGAZINE : “THE ANTARCTIC PETREL "}

S a slight relaxation from the more strenuous
occupations of the voyage, painting ship
and so forth, we started a Magazine. I believe it is a tradition on such expeditions to do so. The Captain was Editor-in-Chief, Doc Acting Editor. All on board entered into the spirit of the thing, quantities of what you agree under the circumstances to call "poetry" were produced, and some of the sailors contributed very decent sketches, and very weird yarns, and reminiscences of the sea-and we had pages of axioms, and "Roast Chestnuts," and jokes, the points of which could not possibly be perceived unless you had sailed on the Nimrod.

The Editor concerned himself mainly with exercising his veto on unsuitable matter, and, to do both editors justice, they were not hard on us-they did not reject much.

The acting editor proved a voluminous and versatile writer, giving us, among other things, a "History of Canada," "Day-Dreams," "The Nimrod Alphabet," and he also wrote upon Epitaphs, 


\section{MEMORIES OF ANTARCTIC DAYS}

lengthily upon Germs, and very entertainingly upon his "Early Experiences."

From this last I will quote the verse of poetry in the French Habitant style with which he concludes. It is a quotation from Dr. Drummond's poems and contains a sound recipe for not getting drowned at sea. It is apropos of the wreck of the wood scow, Julie Plante, on Lake St. Peter.

"So all you wood scow sailormen,

Take warning by that storm;

And go and marry some nice French girl, And live on one big farm;

Then the wind may blow one hurricane, And if it blow some more;

You can't get drowned on Lac St. Pierre

So long's you stay on shore."

The verse with which he concludes his article on "Germs" will also stand quotation, as a sound bit of (American) philosophy. Doc does not say where he picked it up.

“It's easy enough to look pleasant,

When your automobile's in trim;

But the man that's worth while

Is the man who can smile,

When he's got to ride back on the rim."

How the feat is to be accomplished is not explained.

The Biologist produced an illustrated series on "Birds of the Southern Ocean," too deadly serious ever to be read on such a voyage. We had other serious articles on the Compass, and Meteorology, but most of the contributors realized the necessity there was for amusement, and gave us lighter stuff. 


\section{THE SHIP'S MAGAZINE}

No doubt some members of the party could have given us, out of the experiences of chequered careers, much stronger stuff than anything we printed, but for the respect due to the editorial veto.

A few of the articles are here reproduced, as specimens of our work, by arrangement with the Editor, Captain England.

Some of the sketches (alleged jokes) are printed in this chapter; others are scattered through the book, to illustrate episodes. Most of them are not the actual sketches used in the Antarctic Petrel, but versions of the same made from the original drawings.

These drawings, whatever their shortcomings from the point of view of the Art Critic, have their value as records of episodes of the life on board which would otherwise have been entirely forgotten.

\section{DAVID AND GOLIATH}

(One version of a well-known tale). By A. F. M.

Some years ago, while spending a few days in a small village in the ancient Kingdom of Fife, it was my good luck to attend a distribution of prizes to the local Sunday School. The prizes were to be given away by no less a person than the precentor or Choir-Conductor of the free kirk of the neighbouring town, and a bailie to boot.

Bailie Mucklewame was a good-natured old man, fond of children and whisky, and a good storyteller when he was in his cups. He greatly prided himself on his knowledge of biblical history. 


\section{MEMORIES OF ANTARCTIC DAYS}

The prizes having all been disposed of, with judicious words of advice and encouragement, the Bailie, evidently well primed, stood up to deliver the discourse, which was to be the principal event of the function. He evidently intended to speak down to his audience (which, indeed, was very juvenile), for he began-à la paterfamilias :- "Come awa', noo, bairns, and I'll tell ye the story of David, a wee bit tousie-headed country bairn, that rose to be king o' a' Israel. - Noo David was the son of Jesse, the son of Abimelech, the son of Bildad, the son of Mahal-Shalal-Hash-baz (all this the result of much hard reading), and he dwelt in the land of Gilgal. And he wis jeest a wee bit fairmer's laddie, doyin' his peerie, or playin' tig, maybe, like the rest o' ye.

"Noo the war was sair in the land o' Israel in thae days, and the Philistines vexed them sair. For although Samson slew thoosands and thoosands wi' the jaw-bone o' an ass, he wasna leevin' then. But the war was awfie sair, and Saul, him that was king o' Israel, says :- 'Whit in a' the wide world am a tae dae noo?' he says.

"For, tae pit the peter on it a', the Philistines had gotten a muckle giant called Goliah, and there wasna a man in Israel wad face him, for they were a' feard o' him, he wis that strong.

"Sae Saul says :- Whit am a tae dae noo?' he says, 'Man, if I could jeest get a felly tae fecht Goliah, it wad be a' richt, an' I wad mak him king.' But he said this sort o' hasty-like, and no' thinkin' weel what he wis sayin'.

"Weel, tha wur an auld felly Samuel sittin' near- 


\section{THE SHIP'S MAGAZINE}

hand, that wis a prophet, and he wis Jesse's guidbrither, and kent David fine, and sae when he sees Saul like this he says :- 'Behold,' he says, 'is there no David, the son of Jesse, the son of Bildad, the son of Abimelech, the son of Mahal-Shalal-Hashbaz, that's leevin' in Gilgal, doon by the burn Kedron? He's an awfie smairt laddie, about saxteen past, and jist oot o' the sixth standard, and he's got three brithers in the Mileechy. They were tellin' me he was a gran' han' at flingin' stanes. It wis jeest last Wednesday, whiles he was mindin' his sheep, when two muckle she-bears came up oot o' the wood, fair tearin', and wad ye believe me, he kilt the twae $o^{\prime}$ them wi' yin shot frae his sling.'

"Sae Saul answered and says:-'Awa' an' get. him.'

"Neist day was Saturday, and David's mither, no' thinking onything o' Goliah, says till him'Davie, ma man,' she says, 'ye'd better rin wi' yer brithers' dinner the day, up tae the Camp, as soon as the schuil scales'-which it was used for tae dae at twelve on Saturdays.- 'Here's a pickle corn, and a wheen scones an' croudie, an' a tinnie o' soor milk, and see ye'll no brake the wee bottle'for ye may be sure she didna forget that. 'And mind ye'll no' be seekin' birds' nests on the road, noo, or ony o' yere nonsense, for yer brithers will be wantin' their dinners, puir men, and see ye'll bring back the tinnie. An' Davie,' she says, 'gin ye see yer Uncle Sam, tell him we ha'e a fine forequarter o' lamb we could spare him at fivepence ha'penny the pun.' 


\section{MEMORIES OF ANTARCTIC DAYS}

"Off gangs Davie whustlin', as prood as he weel micht be, tae see a' the sodgers, an' him wi' three brithers in the Mileechy.

"Jeest as he wis gaein" ower Jordan Brig, up comes Samuel ahint him, drivin' in the post-cairt, for he'd been ower at Endor, wrestlin' in the spirit wi' an auld besom o' a witch, that was used tae leeve in a cave there. 'Weel, Davie Jesse'-says auld Sam-' hoo's a' wi' ye the day, and hoo's yer faither keepin', an' hoo's the lambin' gaein' doon by ?'

"' 'Fine, sir,' says Davie, 'an wad ye gi'e me a lift as far as the Camp, if ye're gaein' that road, for I'm wi' ma brithers' dinner that's in the Mileechy.' " 'Surely,' says Samuel, ' jump in ahint the cairt. I see ye ha'e brocht yer sling wi' ye,' he says. “ 'Aye,' says Davie, 'I thocht I micht chance for tae get a young raubit, or a paiterick for ma dinner.'

"'Man, Davie,' says Sam, 'I could tell ye o' somethin' far better nor a raubit tae fling at.'

" "What's that?' says Davie.

" 'Jeest Goliah o' the Philistines. Ha'e ye no' heard tell o' him tae the Wars?'

" ' 'Oo, aye,' says Davie, ' fine that. But he's a muckle giant, is he no'? Ma big brither Abiathar is fear'd for tae taickle him, say what wad I be daein' flingin' stanes at him ?'

“" ' Hoot,' cries Sam, 'ye could stan' ahint a bush, whaur he'd never see ye.'

"Weel, when they came by the Camp, there wis a' the Airmy gaein' oot for tae fecht the Philistines, wi' banners, and trumpets, an' a'. But some of 


\section{THE SHIP'S MAGAZINE}

them were a wee thing scared, I'm tellin' ye, for Goliah, and they were sayin' yin tae the ither'I hope he'll no be there.' 'Man, he's an awfie man, that,' an' a' this.

"When Davie seen a' the sojers in their red jackets and spats, and his three brithers that was in the Mileechy, he loupit oot o' the cairt, and ran ower tae them.

"But his brithers gied him the hight o' abuse, sayin' till him-'awa' hame oot o' this, ye young mischief, ye ; awa' home tae yer mither and mind the sheep.'

"But Davie followed aifter them for a' that. But the Airmy didna gang that far, for they were jist past the burn ca'ed Shiloam, when oot comes Goliah, stampin' and roarin' like a wild lion.

"' Whit's a' this,' he cries. 'Whit's a' this ? Is it a fecht ye're wantin'? Come oot here, some o' ye's, and I'll ca' the brains oot o' ye.'

"The Airmy a' stoppit, but Davie says tae his brither-'Oh, Jock,' he says, ' haud ma basket an' I'll try him wi' stanes.' An' afore ye could say 'Jake Robinson,' he was doon in the burn getherin' up stanes and chuckies, an' syne he creepit ahint a whin bush, an' commenced firin' an' firin' wi' his sling.

"Goliah seen the stanes, but he didna see wha wis flingin' them. But he stops and cries, stannin' there, jeest like a policeman, 'Wha's that flingin' stanes?' he says, 'I see ye noo. Come oot fae ahint yon bush, or I'll report ye tae the schuilmaister.' No' that he did see him, but he wis jeest pretendin'-like. 


\section{MEMORIES OF ANTARCTIC DAYS}

"Davie wis a wee thing fear'd at this, sae he cries-'Eh, Maister, I'll come oot if ye dinnae hit us.'

"Goliah comes trampin' ower tae the whin bush, Then puir wee Davie didna ken whether tae stan' or tae rin. But he pits yin mair stane in his sling, and flings it, and it jeest skipps him on the lug. "'Here, watch what ye're daein', says Goliah.

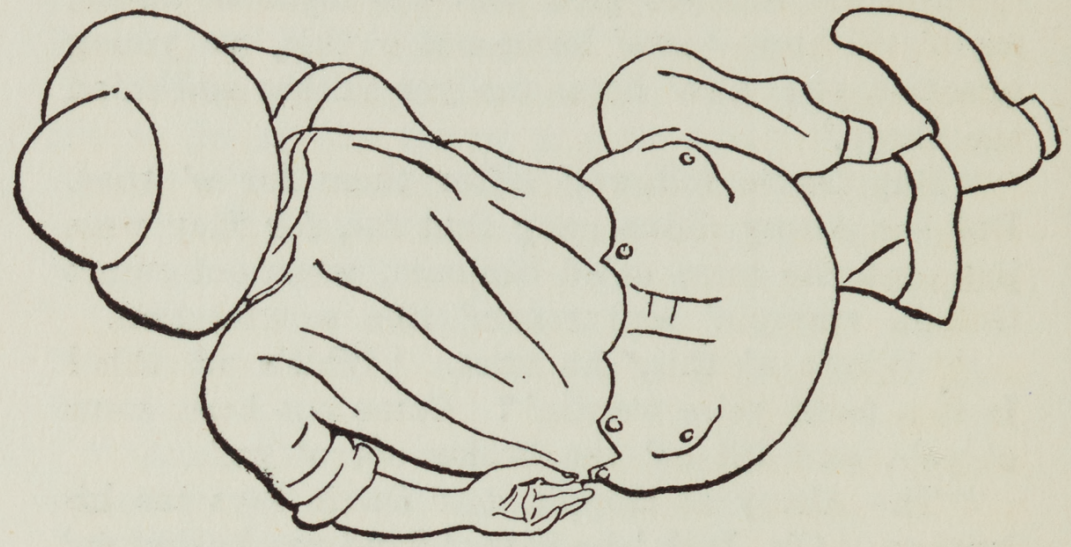

Strenuous Days on the " Nimrod": Keeping the Medical log. (From the "Antarctic Petrel.")

fair wild, 'that's sair, mind ye.' Davie says naethin', but flings his last stane, a braw roon chuckie, an' it skelpit Goliah fair on the broo, and he fa'ed doon like a stot.

"Then the Philistines a' ran off. David cuttit off Goliah's head wi' his ain sword, an' held it aloft, cryin' in a loud voice, 'Saul has slain his thousands, but David has slain his tens of thousands.' 


\section{THE SHIP'S MAGAZINE}

"An' that's hoo they cam' tae mak' him King o' Israel," concluded the Bailie, rather inconsequently.

\section{FIRST EXPERIENCES IN OUR MOTOR LAUNCH}

Went for a trial spin round Cowes Harbour, the builder of the launch being with me. His tongue kept going about a dozen more revolutions per minute than the propeller, explaining to me all about Feathering Gear, Sparking Plug, Needle Valve, and several other parts of the mechanism too numerous to mention. However, like a dry sponge, I tried to take it all in, and after manipulating the manœuvring valves a few times, considered myself fully competent to manage the motor.

We eventually proceeded to the builder's yard to fill up our bunkers with petrol, not forgetting to take a little lubricant ourselves. Then the launch was handed over into my full charge. Our worthy second officer took the tiller, gave the word to go ahead, and then my troubles commenced.

I got down on my knees and pulled the flywheel of the engine round several times, then it suddenly dawned upon me that I had forgotten to open the petrol supply cock at the tank, and also to connect up battery to sparking plug arrangement. However, this was soon done, then down on my knees once again, and tugged at the wheel for a time, when lo and behold my reputation was saved; the little devil shot off at the rate of knots. I tried not to smile, and gave the second officer a very knowing look, as 


\section{MEMORIES OF ANTARCTIC DAYS}

much as to say, "Ain't I clever ?" He returned the look with one which meant, "By Jove, old chap, you are."

Well, we had a glorious spin round the harbour, time after time remarking to each other what a little beauty she was, and so easy to manage. As we approached the Nimrod all eyes were upon us, so we determined to bring our charge alongside in grand style, and would have done so, only the companion ladder seemed to grow suddenly broad, so that we bumped clean into it, but fortunately without doing any damage.

After lunch, Lieut. Adams asked me to put him on board H.M.S. Berwick, so I got the launch alongside. By this time our third engineer had had a few lessons, and could also drive the motor. The second officer being busy, our worthy doctor took his place, and off we went.

It only took about five minutes to get the engine started, and I had to acknowledge, like the second engineer of a late Expedition ship, that "She is a bit awkward at first, but she'll start directly." We got alongside the Berwick without any further trouble and started on the return journey.

About halfway back the motor slowed down, gave a few nasty coughs, and then stopped. I immediately sprang forward to instruct the third engineer how to restart, but not a start would she. I turned all colours, pulling away at the flywheel, opening and closing cocks, the air becoming quite blue with horrible swear words.

I became utterly exhausted, and then the third 


\section{THE SHIP'S MAGAZINE}

had a spell at the wheel. It was not until he had used up all his vocabulary of swear words that she again showed signs of life, and off we went once more. Neerless to say I did not try to look wise, but sneaked aft to my seat by the tiller, having fully made up my mind there would be no more motoring for me that day.

During the evening we had the misfortune to come in contact with a submerged pile, which knocked the propeller blades off. I had promised to meet our leader next morning at $\mathbf{1 1}$ a.m., and if possible to get a competent man to drive the motor. The builders came to the rescue, and had the launch in working order at 10 a.m. Unfortunately they could not supply us with a driver, being so busy, so that I was in for another experience.

We met our leader and his party at the time and place appointed, and pushed off about 11.30 a.m. for the H.M.S. Berwick. The motor seemed to know who was on board, as right merrily did it spin along, the piston, connecting rod and crank humming a gay old melody as we cut through the water at about six knots per hour.

There was a fairly heavy sea on, and it got heavier as we neared the Berwick. However, we got alongside her and disembarked our passengers without the slightest hitch. We pushed off on our return journey.

I had previously made up my mind to show the Man-o'-War folk how we could handle our launch, and that, although we were common kitchen or garden merchant service men, we were second to none, 


\section{MEMORIES OF ANTARCTIC DAYS}

when, to my surprise and disgust, the motor let me down by absolutely refusing to start.

I tried all I knew, but in vain. There we were, two men in a boat, utterly helpless, and drifting away before the wind and sea. I was tugging away at the wheel, opening and shutting cocks, until at last the Berwick's launch came after us and brought us alongside once more.

By this time I was feeling very sea-sick, owing to the smell of burnt petrol and the heavy pitching of the launch. But she had to be got going, so I opened up the ignition plug, found it very dirty, cleaned it thoroughly, and replaced it, tried the engine, and away she went. This was a fine exhibition under the scrutiny of the Royal Navy, and I can assure you I cursed and swore till the air was blue.

My leader sang out from the deck of the Berwick, to know if we were all right, and as I looked up to reply, lo and behold, there were all her crowd, each face with a broad grin on it. Oh, Lor'! how I did feel, but, as a certain gentleman remarked, there are moments when one wishes to be alone and unseen. However, I must again confess she was a bit awkward to start.

I went aft and sat beside our second engineer, who whispered sweet words of sympathy to me. We rattled along against a head wind and sea for about forty minutes, when the darn thing again stopped.

By this time we were both wet through, as she was shipping heavy sprays. I again did everything in my power to get her going, and after pulling at 


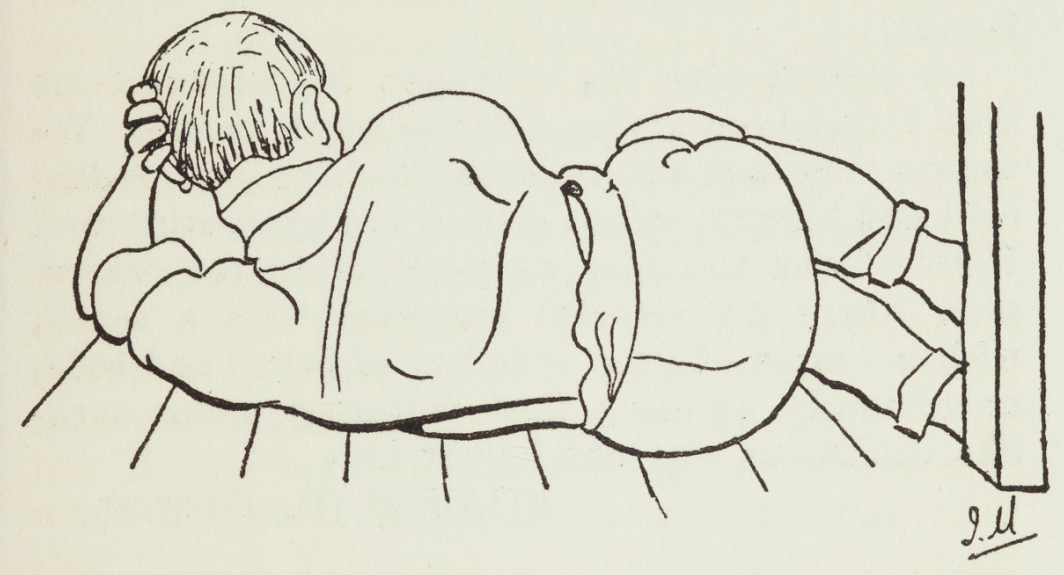

"SANDY"

The tame Scientist, pet of the wardroom. Sandy, to which name he readily answers, is a well-grown adult $\delta$.

Note! The Scientist (Homopsis caledonicus Murray $=H$. dormiens Davis) is one of the little known larger Anthropoids, of which two fine specimens, recently discovered in the wilds of Caledonia, have been taken on the Nimrod as mascots. They are quite tame, have many pretty little ways, and havelearned to sip liquor from a glass.

Naturalists consider them little inferior in intelligence to the Chimpanzee. Unfortunately they are nocturnal in their habits, and so spend most of the day in sleep.

(From the Antarctic Petrel) 


\section{MEMORIES OF ANTARCTIC DAYS}

the wheel, cursing, and between whiles feeding the fishes, gave it up as a bad job, and accepted the offer of a tow to the motor-works by a Man-o'-War's launch.

On interviewing the manager, he informed me that I had been giving her too much petrol. We were a very wet and miserable-looking pair, feeling cold and hungry, so not getting any sympathy from Motor-Works and Co., we went off to the nearest pub, where we consoled ourselves with a snack, with a couple of good nobblers of petrol and soda, unanimously agreeing that motoring under suchlike conditions was not in our line.

\section{FILINGS (H. DUNLOP.)}

\section{EXTRACTS FROM THE NIMROD ALPHABET}

By Rusticus (Dr. Michell)

A is for Anchor, where Davis toils, And leans o'er the cathead in vain; And longs for a good old capstan song,

Or a chance to swear out plain.

F is the Fun we all expect

When the stormy winds do blow;

When the deck's awash, the sails reefed in, And the Scientists battened below.

$\mathbf{K}$ is for "Kismet"- tis the Arab for "fate," A word which we all must learn; For we may go visiting Davy Jones,

Or in glory make our return. 


\section{THE SHIP'S MAGAZINE}

O are the Ornaments up on the bridge,

Almost any afternoon;

Curled up in graceful attitudes, Hoping for dinner soon.

Q is the Quickness always displayed, Whether for work or for fun :

For punch-ball, for skipping, for exercise,

Or anything under the sun.

T is the Tow-net oft seen astern, Which exposes the life of the deep; Where Scientists fish from morn till eve, And in whisky their specimens keep.

$\mathbf{X}$ is the eXtra work we do, But it's all in the game, my boys;

And blistered hands, and aching bones, The amateur sailor enjoys.

$\mathbf{Y}$ is Yours truly, a medicine man, Who has no wish to offend; But who can offer no guarantee A broken heart to mend.

\section{AXIOIMS AND ROAST CHESTNUTS}

The honest man goes to leeward. (Mac.)

She (the Nimrod) would roll if she were in the British Museum. (J.M.)

Some men go to sea for pleasure. (Rusticus.)

Genius is an infinite capacity for taking-beer. (A.F.M.) 


\section{MEMORIES OF ANTARCTIC DAYS}

Never say die while there's a drop in the bottle. (A.F.M.)

Work is the ruin of the drinking classes. If whiskydrinking interferes with your work, give up your work. (A.F.M.)

\section{ADVERTISEMENT}

J. K. Davis and Co. have vacancy for medical or scientific man wishing to learn painting and general marine decoration.

\section{A YARN WITH THE CAPTAIN \\ By Curly (Bull)}

Curly: "I had a yarn with the captain, this morning."

Rufus: "Yes, and what did he say?"

Curly: "Sez he, 'Luff, you cock-eyed, knockkneed lubber, luff.'"

Rufus: "Yes, and what did you say?"

Curly: "I ups, and sez I,-'Aye, aye, Sir."

\section{REJECTED MANUSCRIPTS}

Everybody who has had a manuscript declined by an unappreciative editor, knows that that manuscript is miles better than lots of the stuff that's going about. He bides his time till some appreciative editor shall be found, and then he will triumphantly show that other one.

The editors of the Antaretic Petrel rejected certain skits and sketches (no doubt quite rightly), not, I 26 


\section{THE SHIP'S MAGAZINE}

imagine, from any literary delicacy or squeamishness, but rather because they contained too palpable hits at local celebrities to be admitted. They were afraid of wounding local susceptibilities.

Changes of time and place should by now have removed these scruples, and a number of the rejected MSS. are reproduced in a later chapter, such as those dealing with the affairs of the Scientists.

Our respected mate, at whom most of the skits are levelled, will surely not, at this distance of time, consider that I am hitting too hard, or below the belt. If he is inclined to think so, let him reflect that I am only getting a little of my own back for the number of times he has haled me forth at midnight or the early hours of the morning, to haul on the lee fore braces, or to do some other fool thing called by a technical name. 


\section{MEMORIES OF ANTARCTIC DAYS}

\section{CHAPTER III}

\section{A NATURALIST ON THE OCEAN}

\section{WORK ON BOARD}

T must not be supposed that we passed our entire lives on board the Nimrod in the

1 exciting occupations and amusements of which we have evidences in the sketches scattered through earlier chapters. We had work to do.

By "we," I do not, of course, allude to the officers and crew of the ship. They were at work night and day, keeping their watches, and watching the weather, and, generally, getting the old packet to New Zealand as quickly as might be. But we, the Scientists, the passengers as it were, had our allotted tasks.

One of us had to hunt and catch, if possible, every kind of thing that lives in the sea, from Basking Sharks and Giant Rays twenty-seven feet across, to the minutest microscopical specks that existthe other had to catch and skin all things which fly in the air.

The opportunities for using the nets were not very frequent. The full-speed net, a long narrow cylinder, could be used at all times, and was used daily, but it had disadvantages, and only got surface things. 


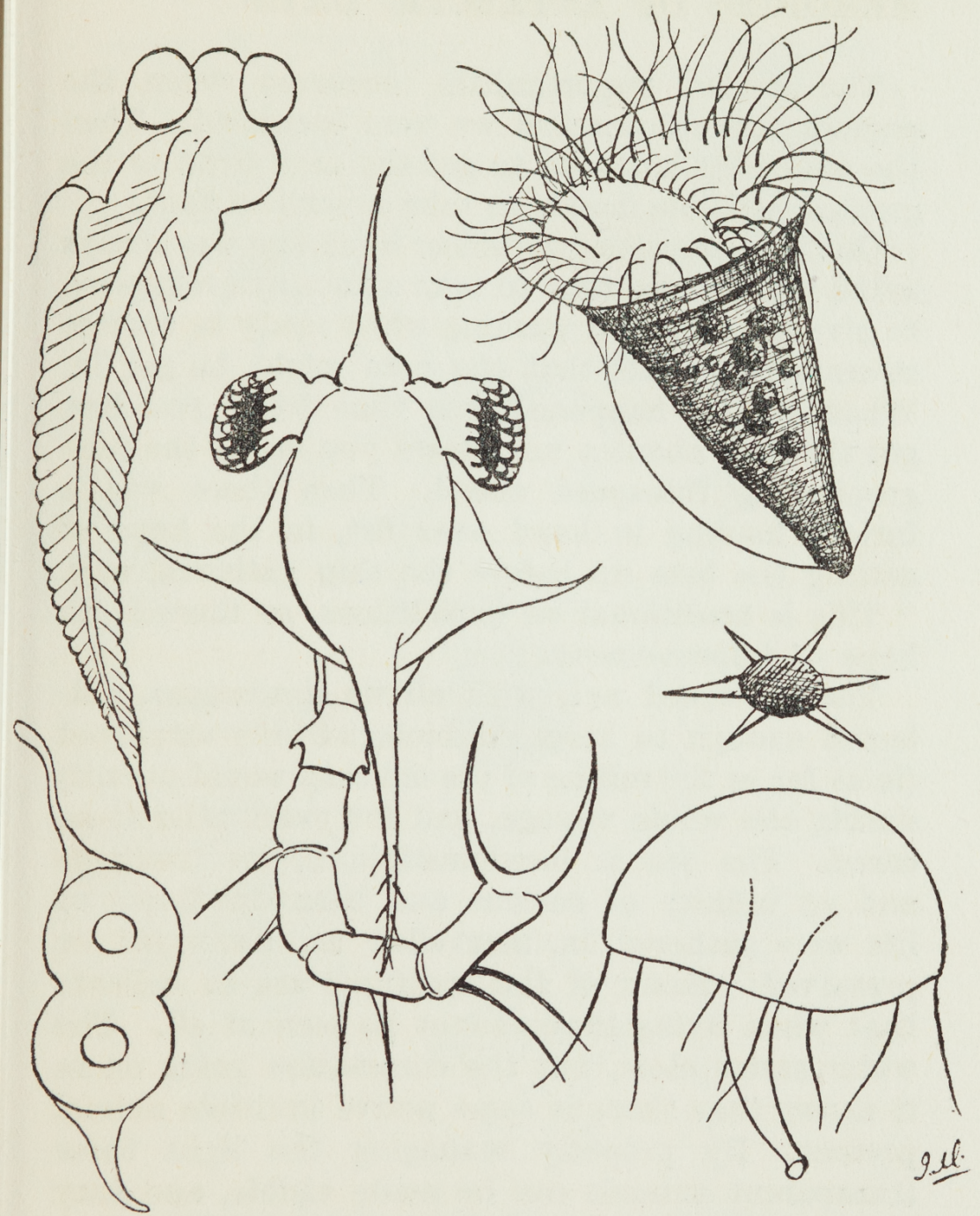

Strange Things Which We see in the Sea

The weird creature in the middle of the plate, with great stalked eyes, formidablelooking spines, and tail like an earwig, is a young shrimp (or Crustacean) of sorts. In the upper left-hand corner appears to be a young fish. In the lower right-hand corner is a small Medusa, or Jelly-fish. I can put no names on the others. 


\section{MEMORIES OF ANTARCTIC DAYS}

The golden opportunities occurred when the engines broke down and we were becalmed. Then the naturalist hastened to get the nets down to the greatest possible depth, to take a vertical haul.

On these occasions the officer in charge was always asked if there was time to take a haul, and requested to give ten minutes' warning when ready to resume steaming, in order that the nets might be got in. What usually happened was that when you had got the nets about a mile down you heard the telegraph ring full-speed ahead. Then there was a furious hauling in hand over fist, in the hope of getting the nets up before the ship gathered way.

This is traditional on expeditions, so there is no hope of improvement.

The full-speed net, with all its limitations, collected enough to keep the biologist fully employed (in so far as the rolling of the old ship would permit) during the whole voyage, and for years after if he cared. The sea is inexhaustible in its treasures and an infinity of curious and beautiful forms of life were gathered in, marvelled at, destroyed or preserved. Many of the creatures are so delicate that when living they cannot be seen at all. The water seems clear, but the commotion going on in it shows that there is some active invisible animal present. By properly managing the light these transparent animals can be made visible, and may prove to be quite large.

Among the most frequent captures are lovely little jelly-fishes (Medusæ), Crustacea of an endless variety of forms, some with the eyes as large as all 


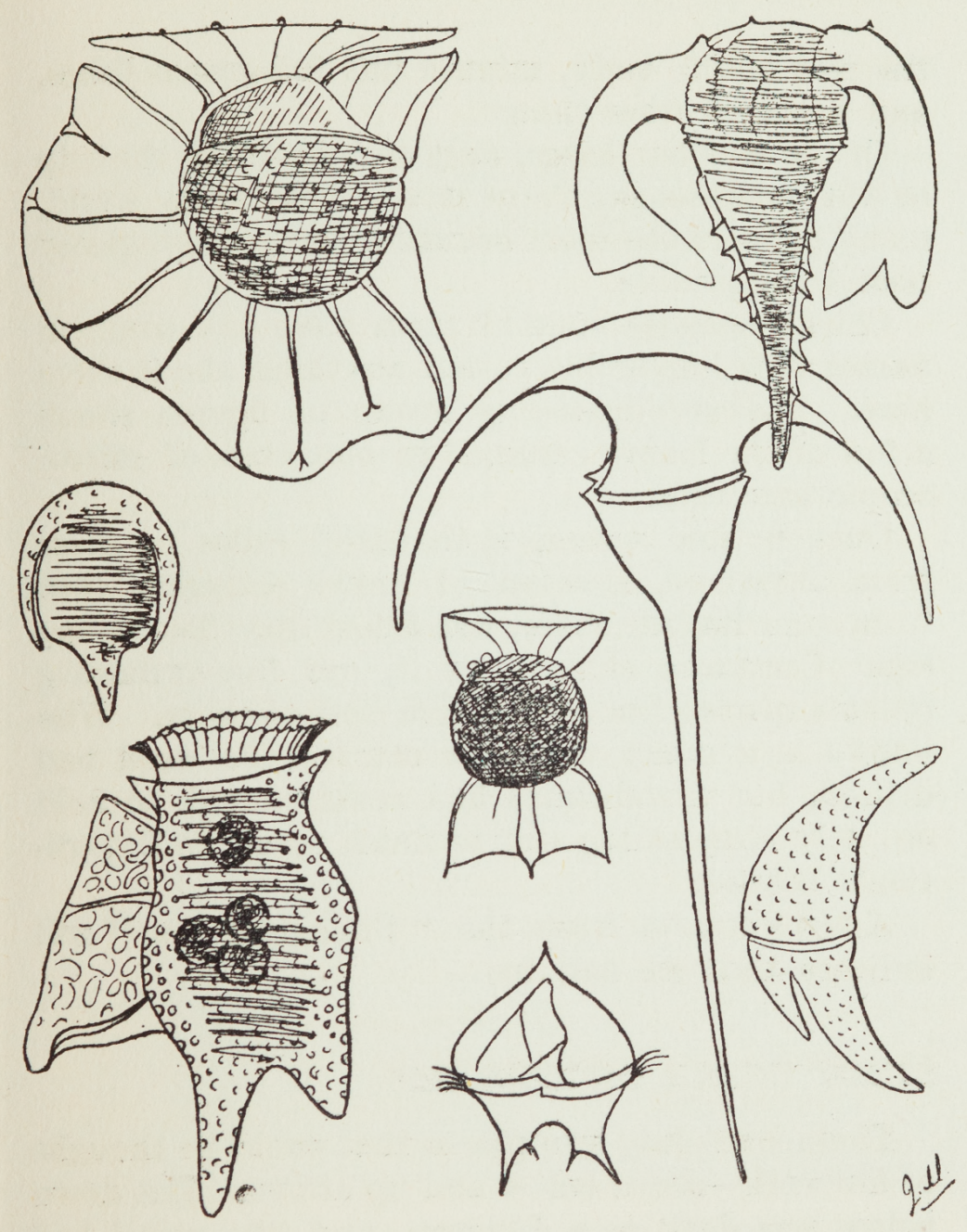

\section{Strange Things which We see in the Sea}

This plate shows a few of the myriad beautiful forms assumed by the animals of one group, the Peridinians. Some naturalists claim that they are plants, and indeed they are near the border line. They swim by means of whip-like hairs, just like many admitted animals. 


\section{MEMORIES OF ANTARCTIC DAYS}

the rest of the body, minute but full-grown fishes, and hosts of other things.

Of the smaller things, only to be seen by the help of the microscope, there is another whole world, many of them the most beautiful transparent glassy bodies imaginable.

Chiefly because none of them have any common names it is impossible to tell anything about them here. The accompanying group of figures shows a few of the forms assumed in one class of microscopic creatures.

Once in mid ocean, a thousand miles or more from anywhere, a scrap of brown seaweed, torn from some distant shore, was fished up. There were some Crustacea clinging to it, not free-swimming oceanic species, but such as live close to shore. Who knows how many weeks or months the weed had drifted, but the shrimps had sense enough to hold on, only alas, at the end to finish up in an Expedition's bottles.

A few extracts from the "Biological Log" will indicate that we had to

\section{STUDY UNDER DIFFICULTIES}

There were only two places that could be thought of for work-down below and up above. But down below was dark as a dungeon, and (the vessel had been sealing for some forty years) it stank. Up above - well, if you had seen the Nimrod when she left Torquay, the decks hampered with coal so that it was an athletic feat to get from our cabins (?) to 32 


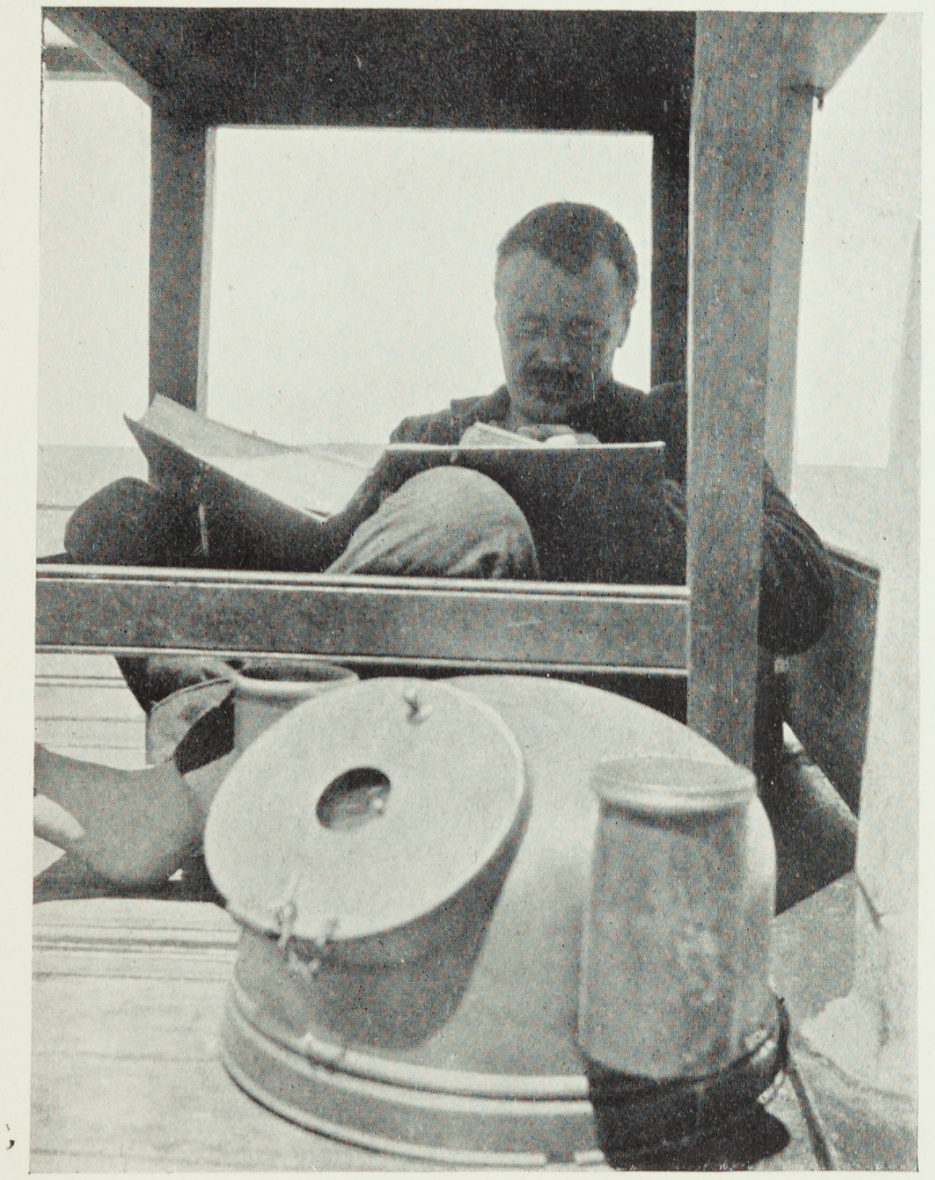

Studying under Difficulties: In the Tropics.

Attempting to study a ponderous "Challenger" volume in the only available shade, under the Chart-box on deck. 



\section{A NATURALIST ON THE OCEAN}

the wardroom (saloon), and everything awash! But we must work.

August 9 (two days out).-Try fishing. This is done by putting coarse and fine nets out over the stern, the only available spot, when you must perch on sacks of coal as you fish. On one side is the patent $\log$, on the other a sounding machine (in use, for we are still in "soundings") giving two chances of fouling the nets.

After a time the nets are drawn in and emptied into a jar ; the ship rolls, the jar is upset, and all is to do over again. In the midst of the second attempt the order is given to make sail, a crowd of sailors come trampling around, the nets are hurriedly hauled in, and in the confusion of tangled line and sailors' legs, one net is trodden into holes (£1 gone!). I work no more.

The two great enemies to work are dirt and damp. Everything is clammy with moisture. Our cabins are the driest places aft, but are uninhabitable from smells and darkness.

August 11.-If anything should be caught there must be a table to work at. The Old Man offers me his camp table, and then before my eyes, and in spite of my protest, it is packed away down in the hold, to stay there till we reach New Zealand. You see, the promise and the fulfilment are under different authorities.

The mate promises to have a table made for me on deck, but it is an utterly unimportant matter, there is no hurry about it.

Having a successful catch to-day, tried working 33 


\section{MEMORIES OF ANTARCTIC DAYS}

on the wardroom table, but the microscope toppled over.

August 13._-"Unveiling" of my work-table on the bridge. Now I am much happier. I can work.

We are sailing into the Tropies, and the sun is already hot.

There is an awning over the entire bridge deck, but it does not give enough shade till the sun is high.

August 16.-Down below there are other troubles for the would-be worker. The library, of ponderous volumes of the Challenger Reports and such-like, is there, piled on a spare bunk in my cabin; and there are also stores of jars of various sizes for preserving the catch.

Going down to bed to-night, I find that all the library, and other rubbish, have been piled on my bunk, and the cabin filled with stores up nearly to the deck above. It was a feat climbing over the mountain to get to the side on which my bunk was. Then I had to quarry out enough library to give me room to curl up in.

August 19.-My work-table on deck has been discovered by the Navigating Officers, who find it comfortable to sit at, so that when I go to work there I usually find some one sitting at it writing logs. I determine to build me a table in the dungeon below and to work by lamp-light.

August 20.-Have a successful fishing, and set to work. An officer is writing his log at my table; try the wardroom, spread out my things; get half a dozen curious animals on a slide to be drawn. A warning is brought that the mate is heaving all my 34 


\section{A NATURALIST ON THE OCEAN}

precious belongings out of my cabin; I rush off to save the remnants.

The Chief Engineer brings another warning that the microscope in the wardroom is in danger; I rush back to save that. Find there isn't any table in the wardroom now. The microscope, slides, bottles, and all my gear have been swept off and lie about amid a heap of shavings. Chips has been set to alter the table; truly they chose an opportune moment.

Gather up things in disgust. Dunlop is heard to mutter that it is a d- shame, and he rigs up a drawing board in his bunk, where I work standing for two hours.

August 21.-On going on deck I find written in bold letters of blue across my work-table: "This table is reserved for the use of the Scientific Staff only." The mate has taken the matter up-Hurrah!

August 27.-On the day on which my table received its charter we entered the Tropics, and a few days later made St. Vincent. Immediately after leaving there the deck awning was removed. (WHY ? ? ? ?)

No work on deck was possible thereafter, and we had fresh troubles, a new deck cargo of coal, which incidentally covers the few inches of skylight which was the source of the only little light we got below; everything filthy with tar, coaldust, seawater, etc.

Can only work now by favour of Dunlop, who kindly permits me to work on a board in his bunk, and now the heat and humidity causes such a drip 


\section{MEMORIES OF ANTARCTIC DAYS}

of sweat that it is impossible to either draw or write.

October 6.-After leaving Cape Town you hardly experience any more calm weather as long as you are " running the easting." You are spanking along before the steady westerlies, with a following sea; it is an exhilarating bit of yachting, but it is not exactly favourable to scientific work.

But we have now settled down to ways of doing, made some sort of terms with the mate, and fishing goes on daily with more or less success. The only variation in the conditions is between the ship rolling a good deal and the ship rolling a good deal more (a good deal too much).

It is not easy to work at the microscope on a ship rolling 50 degrees or so, but it can be done. All such work is done down below now, at a table fixed in a narrow doorway, so that a roll either way soon brings me up safe against a door-post. The microscope, bottles, and everything else is chocked up or otherwise secured.

The attempt to make drawings of the animals collected required other contrivances, and in this direction there always remained a good deal to be desired. A drawing board was placed in a bunk at such an angle that the worst roll would not displace it. Ink-bottle, pencils, pens were jammed between the mattress and the board. I sat on a box carefully chocked in all directions.

Even thus it was not easy to maintain a proper balance and steadiness of line. When the roll of the ship is tending to throw you bodily on to the drawing board you are apt to bear a trifle heavily, and make 


\section{A NATURALIST ON THE OCEAN}

a thick line, while with the roll in the other direction you can scarcely keep the pen or pencil on the paper.

With an extra heavy roll, accompanied by a screw, I would sometimes be lifted clean off my seat, describe a curve through the air, and bring up against the opposite side of the cabin.

It was most difficult of all to control the furniture, especially the library. If the books were to be got at for use they could not be packed away beyond all possibility of motion. It often happened that a heavy roll brought the big Challenger Reports about my ears, a genuine danger. Once a specially heavy roll brought all sorts of things rattling around ; a heavy box of glass bounded through the air and just missed my head; the lamp left its support and fell on my board, tearing the paper I was writing on.

November 9.-Nets out; caught only engine ashes.

Dunlop remarks on the seeming conspiracy to throw dirt overboard when the nets are out-first the cook will empty his bucket of slops, then the stokers must throw out ashes; Chips puts shavings overboard, and the watch sweep the filthy decks -and these are only some of the things the biologist has to put up with. All comes into his net. Later on paint was added to his troubles, and, worst of all, oil on the troubled waters-ough!

\section{PHOSPHORESCENCE}

The sea may be phosphorescent in all latitudes, from the Tropics to the Polar Seas. The light is generally, if not always, produced by animals. The 


\section{MEMORIES OF ANTARCTIC DAYS}

interest of a sea voyage is greatly increased for a naturalist by the investigation of the various animals which produce light.

Sometimes the sea is flashing with lights in every direction, sometimes there are only isolated patches or minute dots. During our whole voyage it was rarely indeed that phosphorescence quite failed. Even when the net was used under the ice in the frozen sea there were little specks of brilliant light, and when a dredging was brought from the bottom, even the worms had two little electric lamps in every segment of their bodies, and the light flashed from end to end in the most beautiful manner.

One of the most brilliant displays seen on the voyage was caused by an animal called Pyrosoma. It filled the nets with cylinders about an inch in length, each a colony of many animals, and glowing all over with light.

Occasionally a most brilliant spot of light is seen as you turn out the contents of the nets. You locate the spot, fix your eye on it, with a lens to aid. The light goes out. You can detect nothing whatever. Probably the source of the light is quite microscopic.

There is a Crustacean (or Shrimp) common in Tropical seas. I have forgotten its name. It is small, but visible to the naked eye, excessively thin, just like a little oblong scale. It flashes out in the most vivid purple light, disappears and becomes quite invisible; flashes out again, this time in green light-and so on. I don't know what is the extent or limits of its range of colours. 


\section{A NATURALIST ON THE OCEAN}

Away down south of New Zealand a very pretty sight was seen one very phosphorescent night. A number of a sort of dolphin or porpoise were playing with the ship. You could trace their course by the phosphorescence set up by the friction of their bodies as they went through the water. Their favourite game was to swim close in to the side of the ship, get a purchase with their tails against it, and shoot out on a straight course at right angles to the side like torpedoes.

\section{THE BIRDS}

In the north Atlantic and the Tropics bird life is extremely scarce at a great distance from land. On going south of the Tropics it is rarely long before some Albatrosses or other representatives of the great dominant southern family of the Petrels put in an appearance. For the tiny Mother Carey's Chicken and the Giant Albatross are closely related.

Once they are encountered they never wholly disappear while a ship remains in the southern oceans. There may be only one or two Albatrosses in sight, and they may be gliding in huge circles round about you, far off.

Various sorts of little Petrels, variously marked in black and white, come and go.

The Albatross is a master of the mechanics of gliding. For hour after hour I have watched him, hoping to find out his secret. Unless in a dead calm, he never needs to flap a wing, and even then, when he has flapped to some little height, he can indulge in a long series of gliding manœuvres. 


\section{MEMORIES OF ANTARCTIC DAYS}

In a light air he glides easily with or against the wind, circling round the swiftest steamer as though she were standing still, rushing into the teeth of the fiercest gale. How does he do it? You can see nothing except the slightest trimming of the wing or tail.

When wishing to check his flight, so as to avoid too violent a descent on the sea after a headlong rush, he spreads out his tail feathers and his feet, thus checking his speed and alighting gently, as shown in the accompanying rough sketches.

The Cape Pigeon is the prettiest of all the Petrels that accompany the ship. For long weeks he is never absent-a cheery companion in his dainty speckled plumage.

Usually there are only a few birds, or a few dozens, of all kinds present. But sometimes they occur in myriads, and the air is darkened by the clouds of Albatrosses, Mollymauks, Giant Petrels, Mutton Birds, Cape Pigeons, and smaller fry. These great flights are supposed to indicate the neighbourhood of land, but the land may be hundreds of miles away.

On nearing land the Albatrosses disappear, and Cormorants make their appearance, with Gannets, and the beautiful white-fringed Dominican Gull.

- SPORT

Albatross fishing. One of the recognized sports of the voyage is Albatross-hunting. Various methods are practised, but perhaps the triangle is most commonly successful. You make a triangle of brass, or 40 

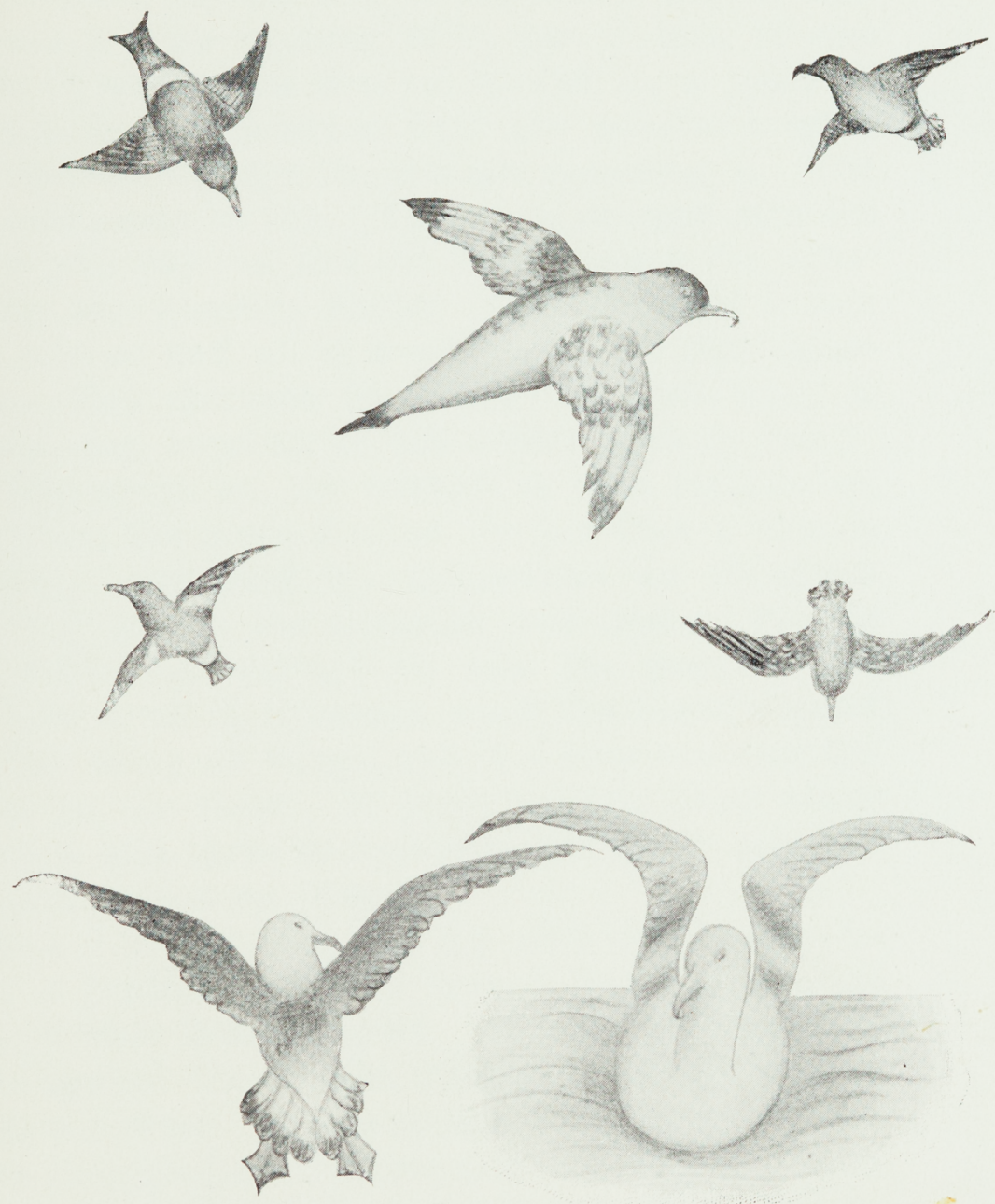

In the Centre is a Cape Pigeon, Round it are Four Small Petrels, below are Two Sketches of an Albatross ALIGHTING ON THE WATER. 



\section{A NATURALIST ON THE OCEAN}

other strong metal, five or six inches across, and cut out a large opening in it, put a hole at one angle to attach the line to it, and fix a piece of meat in such a position that the Albatross must put its beak through the triangle in seizing it. You are now ready to fish. Throw the triangle into the water and pay out line till it gets where the Albatrosses are wheeling about. Soon the meat is seen and seized, and all is nearly over for that Albatross. The moment it strikes the bird loses in momentum, meaning to fall behind with its catch; the ship keeps on, the triangle at once tightens on the bill; the great hooked tip prevents a chance of slip; you haul in. Sometimes an Albatross instantly grasps the situation and tries to run on the water fast enough to ease the pressure. It does not avail it, it cannot equal the vessel's speed without using its wings, and it is now too near the water to use them. It gives in, the great wings collapse, and three or four men can easily pull the draggled wreck on board.

Here I would like, for my own satisfaction, to utter a protest (perfectly vain, I dare say) against most of what is called sport. Man pits his ingenious brain against the simpler intelligence of the bird or beast, and wins. If it is accepted simply as a phase of the struggle for existence, and man kills the beast frankly for food, I have no criticism to offer. Butchers (frank name) have their place in our economy, but they are not classed as sportsmen.

You take advantage of a fish's low intelligence and its hunger, dangle a bait before it, and you get 


\section{MEMORIES OF ANTARCTIC DAYS}

the fish for dinner, but for my life I cannot see that it is anything to be proud of.

You take a clever bit of mechanism which other men's brains devised and perfected, and by its aid you bring down the fleetest stag. Without it you would have no chance against the beast. You don't even, like the old hunters, depend on your own skill in stalking to get within shot of him; you lie, comfortable in a shelter, while the stag is driven past you. He hasn't any kind of chance, except the off one that you may be a bad shot.

The beast cannot hit back; if all your wiles fail, you merely lose him; he doesn't get you. You don't take even chances with him, not even unequal chances; he has no chance at all. If you go tiger or buffalo or elephant hunting, no doubt (sometimes) you take a risk. He may get you if you miss your shot. But always the chances are so overwhelmingly in your favour that there is precious little credit in the achievement. You might depute it to professional butchers and be a better sportsman.

This Albatross-hunting made me ashamed. Here were half a dozen men, the reputed highest product of evolution through all the ages, willing to exercise guile to capture the Albatross; filled with satisfaction, as this marvellous piece of mechanism (to say no more), this glorious, free, untamed sea-rover, is dragged to ignoble ruin in order to give us a slowly-decaying "specimen" in a museum, usually even as such so unskilfully prepared as to have little resemblance to the live bird, and to be a disgust to any one who has seen his like gliding on free wing. 


\section{A NATURALIST ON THE OCEAN}

Once, while surveying in the Highlands of Scotland, I met a party which was calculated to sadden a philosophic naturalist. A party of sportsmen were returning from the hills. They strutted along, overflowing with pride, accompanied by several stalwart stalkers, and quite a little rabble of beaters, gillies, or whatever they are called in this particular "sport"; and in the midst a poor little dead doe (it was after the stalking season) a boy could have carried. Gentlemen, is it an occupation worthy of the heir of all the ages? Is it anything to be proud of ?

I would like to know-nay, I know perfectly well-the feelings of our humane and sensitive doctor as he spent half an hour, and had his fingers frostbitten, trying to chloroform an Albatross, in the hope that this was more humane than tearing its brain to pieces with a big needle.

All this is very unorthodox, especially as it was all done for me, the official "naturalist" of the Expedition. If this must be, then would that I could find an honest, clean trade!

Go out and kill, Englishmen, since 'tis your nature to, but reserve the name "sport" for something nobler. Kill, but recognize it by its alternative name, "butchery."

\section{THE BIOLOGIST}

Having had a tilt at conventional sport, I will now have one at my own profession.

It is surely an irony of fate that the name biologist should be applied almost exclusively to a class 


\section{MEMORIES OF ANTARCTIC DAYS}

of men who live upon the wholesale butchery of their fellow creatures! If we were not biased in the matter, and familiar with the anomaly, surely we would expect to find the name denoting students of life, men who revered life and deplored the inevitableness of death.

Instead, we find the biologist everywhere begin his study of any creature newly brought to his notice, by killing it. Some will, I admit, desire to ascertain first certain fugitive characters, such as colours, which can only be seen in life. But this will almost never be because of any reverence for the wondrous mystery of life itself, any shrinking from the responsibility of defacing and destroying what the Creative Force has brought to be through the working of endless ages. Having noted its colours or other fugitive characters, the "biologist" proceeds cheerfully to kill his animal, and what he calls "preserve" it, as proud of his trophy the while as any sportsman.

It can be advanced in defence of the so-called biologist, that an understanding of the living animal requires an examination of its structures only possible after death. There is some palliation of the offence in this, if not justification.

If the investigation is undertaken with the ostensible object of gaining knowledge which will lead to the alleviation of human suffering, we have a further plausible defence of the slaughter of animals. This aspect of the subject is closely related to the vexed question of vivisection.

While I personally incline to consider justifiable 44 


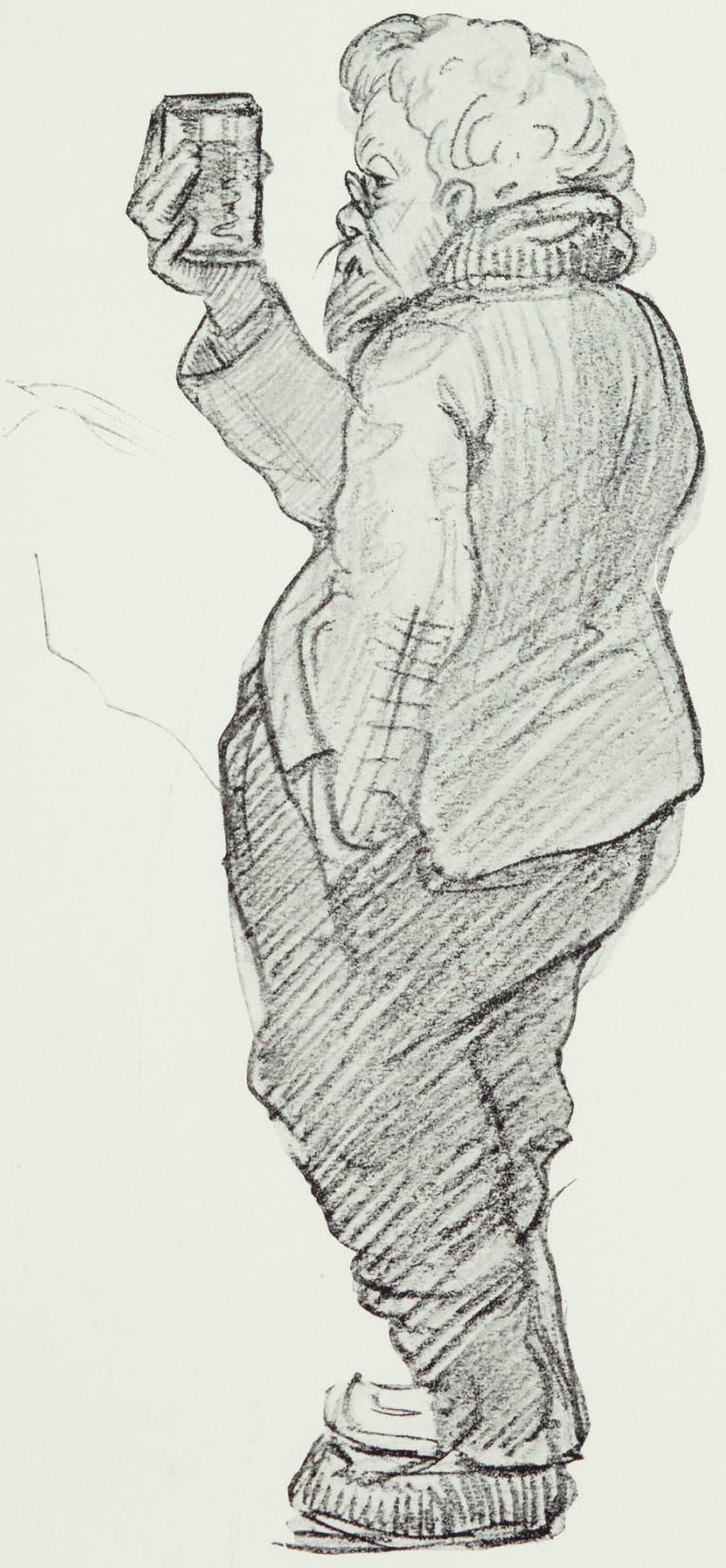

The Biologist.

(Sketch by G. E. Marston.) 



\section{A NATURALIST ON THE OCEAN}

observations and experiments made on living animals by serious investigators already specializing in the treatment of disease, I deprecate the wholesale vivisection and destruction of animals, as at present practised, merely to demonstrate well-established facts in physiology to juvenile classes of students, most of whom have as yet no idea whether they will devote themselves to medicine or not.

If the humane line of argument is used in defence of the latter practice, then reason has become a devil's advocate. If animals may be killed for the increase of knowledge, how much is knowledge increased by the slaughter of the hordes of creatures whose hideously distorted skins disgrace all our museums? If we may kill for the good of science, it would be well to bear in mind Waterton's caution: "Having killed a pair of doves in order to enable thee to give mankind a true and proper description of them, thou must not destroy a third through wantonness."

The biologist may say in his defence that his profession requires it-that, in short, he does it for a living. Well and good-such an admission would at least be honest. The biologist, like the butcher, kills for a living, though not directly by eating the animal killed.

It is, at best, a sorry profession, and many a time have I felt shame for it. My ambition would be, were it not for this sordid necessity of maintaining myself alive at any cost to other creatures, to study every living creature that came within my ken, and never consciously to injure or destroy one. Would 


\section{MEMORIES OF ANTARCTIC DAYS}

not the knowledge, the biological knowledge, thus acquired during a lifetime perhaps exceed all you could get from endless cabinets of dead things, of which you have gained no further knowledge than that they differ slightly in certain external markings? And you could call yourself a biologist then with some truth.

There have been biologists in this better sense. There are living biologists who deserve the name. My strictures do not apply to our whole tribe. But, alas, I find myself among the damned; I shudder to think of the myriads I have slain, if not wantonly, certainly without making any addition to the sum total of knowledge, not even so much as contributing to the dusty, decaying stores of museums. And, thinking of those things, I wish that I could find some honest, worthy occupation in life, in which my fingers would not be stained by the blood of my fellowbeings, and I might perchance contribute something to the sum of good. 


\section{CHAPTER IV}

\section{YARNS OF THE VOYAGE}

\section{THE SCIENTISTS}

WO of the scientific specialists of the Expedition accompanied the ship from England. They lived in a dark hole aft, known as the Scientists' Quarters, which was also a storehouse for many things. They had some real, if minor, grievances, which they attributed to the mate, and a series of sufficiently good-humoured skirmishes occurred.

Various skits on this subject were contributed to the Magazine, some being accepted and others rejected.

The first to appear was the caricature of Sandy, reproduced in an earlier chapter. It was rather a hit at the scientists themselves, though produced by one of them; but it marked out the line taken in the subsequent encounters.

Next appeared a word picture of the scientists (rejected from the Magazine).

Two curious animals of the rare species known as Scientist had been recently captured in the wilds of Caledonia, and taken on the Nimrod as mascots. 


\section{MEMORIES OF ANTARCTIC DAYS}

They are a source of some amusement to the officers and of worry to the mate.

They live in a dark and dirty den down in the hold, whence they emerge and prowl about the ship, prying into everything.

They are certainly anthropoid apes and have a considerable resemblance to men. They walk upright like ourselves, though much given to reclining in pensive attitudes.

They are undoubtedly somewhat higher than the brutes, enough so to let them notice how very differently men and officers are treated from Scientists. They wander among the luxurious cabins on deck, observing everything, then retire to their noisome den to brood enviously over the difference in their lot. The imitative faculty is strong in them, and their great ambition is to do everything " just like men," and this leads to many an amusing incident. It is great to see the little creatures (the larger specimen is no more than 5 feet 10 inches in height) holding tumblers of-whisky in their front paws, and tossing them off like hardened topers.

They do not like their keeper, as they feel he has no sympathy for them; does not appreciate their strivings towards higher things.

Their presumption reached a ludicrous pitch recently-they took it into their heads that they would like to wash, just the same as men. It really seems that, contrary to current report, these animals are fond of water. In the early days of the voyage they would emerge from their den just as the sailors were washing the deck in the early morning, and 


\section{YARNS OF THE VOYAGE}

nothing delighted them more than to have the hose turned on them. They turned about in ecstasy, perhaps reminded by the flow of water of the rains of their native land.

But now the hose is not good enough for them; the weather is colder. They want to wash out of a dish, if you please ; it would hardly be surprising if they went so far as to ask for hot water.

The keeper, in an unexpected burst of generosity, gave them a bucket, told them to go and beg water from the nice sailor man, to beg nicely (they know every word that is said to them). And now for some days they appeared to be content; they trotted with their little bucket to the pump, begged nicely, and quite often got some water. Their bucket was allowed to stand in a corner of the deck.

But alas, there came an end. There was a storm. While the pretty little creatures slept peacefully in their den below, their bucket got loose and rolled about on the deck. It was quite in the way. The mate ordered it to be confiscated, saying: "It's all very well humouring those brutes when it is in a harmless way, but we can't have this. Remove that bauble." (These were his very words, as reported by a sailor.) Now dejection and gloom reign in the Scientists' den, their too soaring aspirations thwarted, they must now relapse into their primitive squalor. Thus they cower and grovel for days. Then a new ray of hope strikes through. Is there not on board a sailing vessel a higher authority even than the dreaded mate? Is it conceivable that our humble petition could reach the august 


\section{MEMORIES OF ANTARCTIC DAYS}

presence? Impossible! Has he ever heard of us, the sailors' pets? Like as not, not. Nevertheless, through the offices of some of the more humane officers, who were fond of animals and had a soft side to the Scientists, it was done. Now we wash in a basin like the rest, and, crowning wonder, on occasion with hot water.

\section{A PARTY IN THE SCIENTISTS' QUARTERS}

It has been related how the Scientists' quarters were largely used as accessory store rooms. In odd corners there were-a huge telescope, boxes of food, cases of lamp chimneys and a thousand other things. On certain occasions, when the mate had been at work, we would return from paying afternoon calls to find the quarters piled with miscellaneous stores, reaching nearly to the roof (deck) above. Over these we crawled on our stomachs to get to our bunks.

At other times the day's supplies were heaped promiscuously outside our doors. The rolling of the ship often caused tins to roll into the cabins. It will not be disputed that an Englishman's house, be it ever so humble, is his castle, and surely it is not stretching the point to apply the same noble term even to his den in a ship's hold. Then who will question our right to eject such distasteful articles of food as we had no use for; and, conversely, when a tasteful article rolled in, who can criticize if we let it alone-hang it all, we didn't ask it to come in! 


\section{YARNS OF THE VOYAGE}

Thus it came about that on October 16,1907 , the Scientists found themselves in a position to entertain friends; the Scientists gave a party. Mac had discovered a thimbleful of brandy, forgotten in some inexplicable way. I had three biscuits and five figs, remnants of stores acquired as above explained, and a little whisky.

On such an important occasion the selection of the guests was a serious matter. The ship's officers proper were barred for one reason or another. The "Old Man" was too far above us in station. The mate-well, he might look too curiously at the viands provided. Mac, the other Mac, was a good fellow, a whisky drinker, it is true, but then, Mac was on watch. Doc, besides being a good fellow, had the advantage of being a teetotaler, and therefore would be no drain on our resources; but he might feel out of place as the only teetotaler among whisky drinkers, so we scored him off.

Eventually we narrowed the invitation list down to one-Dunlop. Dunlop was a good fellow, a man after our own hearts., It was true, he would take some of the whisky, but, he deserved it, so that was all right.

The invitation was issued; the guest came; we spent a happy evening. Ye gentlemen of England who sit at home at ease, can you imagine such a feast? Can you imagine three who had known Piccadilly rioting on a thimbleful of brandy, three biscuits, and five figs? You cannot.

We spent a gloriously happy evening, with song and pipe, and finished up as we three commonly 


\section{MEMORIES OF ANTARCTIC DAYS}

did, on the bridge, rolling Scottish psalm-tunes out into the night, under the brilliant southern stars.

\section{THE SCIENTISTS AND THE BRANDY}

This is a little story against the Scientists. Some kind friends had presented to the ship's company a quantity of strong waters, which were rather sparingly used. On Saturday night a little brandy was issued in order that we might drink the sailor's toast, "Sweethearts and Wives," and on Sunday night a bottle of port for the other sailor's toast, "The old folks at home."

Now, apart from these special occasions, the only liquid we were permitted to have was whisky, and the whisky we had wasn't much liked and was usually left alone. The brandy, on the other hand, was good, but we were not allowed to have any, except to drink the toasts.

The bonded store was close by the Scientists' quarters, but it was presided over by the mate like an ogre. It was no use. One day we were severely tried by seeing a tiny trickle of priceless fluid issuing from under the door, and running away to ruin. But let us not dwell upon this painful episode.

After a time the charge of the bonded store was handed over to Doc, amiable, friendly, kindly Doc, and hope sprang up in the Scientists' bosoms. But Doc, amiable though he was, proved inexorable; after all, he was a teetotaler, and devoid of fellowfeeling. The hope withered and died.

One day, I went down to our den; behold, the key in the door of the bonded store. What could 


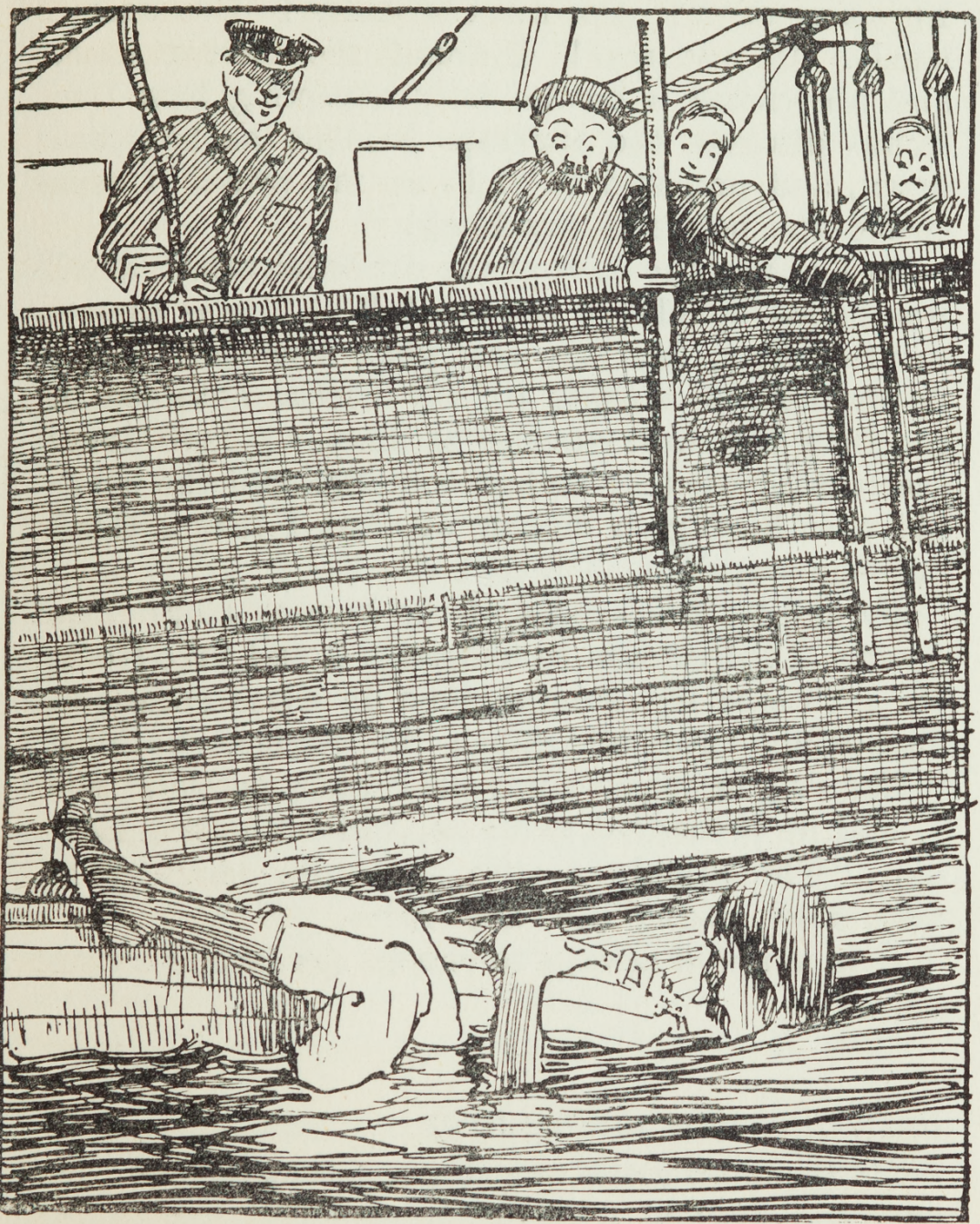

"Come on Board, Sir!" 


\section{MEMORIES OF ANTARCTIC DAYS}

have happened ? Doc must be inside ! Doc wasn't inside. It was real! I found the brandy case, and abstracted a bottle, fully expecting that Doc would discover the shortage as soon as he came down, and prepared to yield up my prize. I concealed the bottle in my bunk.

As I passed the door of the other Scientist's den I was hailed by him in a voice full of joyous excitement-"Hey, Murray, see what I've got"-and he brandished another brandy bottle, obtained in precisely the same manner as mine. I have never ascertained whether he had contemplated the possibility of having to deliver up, but I rather think not-he wasn't such a fool.

By and by the keeper of the bonded store came down. I helped him to rearrange it and take stock, for such was my painful duty on these occasions. Everything was all right; he noticed nothing. "Hadn't you better count the brandy bottles," said I, and he proceeded to do so, while I looked sadly on. "The brandy bottles are quite correct," he said, after taking the tally twice.

It is not well always to run in the face of Providence.

\section{PAINTING THE LIFE-BUOYS}

I was shirking the painting; the mate found me out, and devised a fresh torture. He got all the ship's life-buoys together, decided that they must be repainted, sent for me, and by dint of insistence and flattery, got me to understand that, as the only 
man on board capable of painting in the letters on them, it was my duty to do so. I weakly yielded. The letters to be painted were B.A.E. (British Antarctic Expedition) at the top, N.I.M.R.O.D. at the bottom.

An idea struck me, and I said that if he insisted I would paint B.F. on every one instead of B.A.E. It can be easily seen how, by leaving a space for the $\mathrm{A}$ and omitting the bottom stroke of the $\mathrm{E}, \mathrm{B}-\mathrm{F}$ can be produced. They were all painted in that form, but one was finished B.A.E. and turned with its face to the wall.

The officer in charge entered into the thing, and, when all was ready, he called the mate to see what a mess I had made of the buoys. He came, andfell in; spluttered incoherent rage, and seized a brush to paint the letters out. His hand was stayed till he was shown a completed one.

\section{THE COOK AND THE VISITORS}

I do not know at what port it happened. A smart launch came alongside with visitors for the Nimrod. While they were being shown around, the launch was tied up alongside with nobody aboard of her.

The cook came out of the galley, carrying a large bucket full of assorted slops. In his usual heedless manner, he raised the bucket and emptied it over the rail, without looking where it went.

As it happened, the launch was just at that place, and the slops went right down on the shining engine. 


\section{MEMORIES OF ANTARCTIC DAYS}

\section{THE LOST BOOK}

Through the kindness of various friends, the Scientific Staff of the Nimrod was not entirely unprovided with entertaining literature, of course over and above the official library.

The voyage was long enough to exhaust our store of reading matter, and favourites were read again and again.

There was one particular book which was greatly appreciated, a collection of old chap-books giving most graphic glimpses into the simpler, ruder life of our forefathers of several generations back. This book I valued for its intrinsic merit as an unsophisticated record of not too sophisticated life, and also on account of its giver.

Early in the voyage it was lost, and I failed to find any trace of it, and gave it up as hopelessly gone.

Many months afterwards, when the voyage was drawing towards a close, and we had got to know everybody on the ship, one of the sailors, learning that I was out of reading matter, told me of a very fine book they had in the fo'e'sle, and offered to lend it to me.

He brought it-it was my long-lost chap-books.

\section{A MEETING IN MID-OCEAN}

The weary voyage dragged slowly on, day after day, week after week, month after month. All our amusements palled upon us; we ceased to make jokes; we had nothing more to read; there was no 


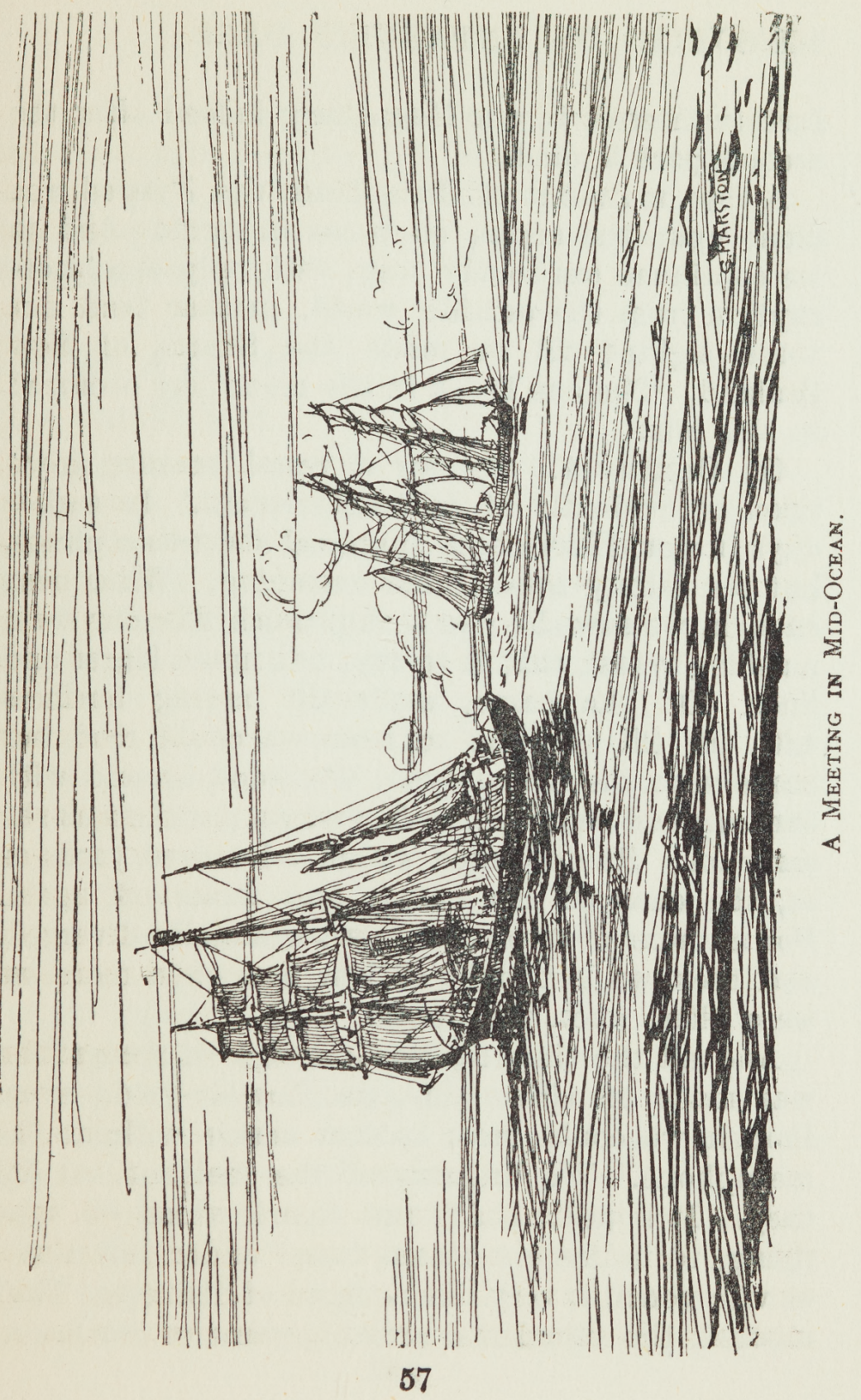




\section{MEMORIES OF ANTARCTIC DAYS}

further interest in our Magazine; indeed after the second part it died.

A few hours out of Cape Town the Nimrod was alone upon the ocean, no vessel in sight. And so we continued our lonely way, with only one interruption from the outside world, neither land nor vessel sighted till we made the Snares of New Zealand. The one break in the monotony occurred in this wise.

On October 21 we saw a vessel bearing down upon us evidently of deliberate intent. In earlier days it would have been supposed she was a pirate, but we calmly awaited her oncoming. When near enough, we saw she was a ship much like our own, a sailing vessel, that is to say, but much larger and finer. On she came, evidently having business with us, till she was so near we could read her name with the naked eye. We stood around with cameras and snapped her in various positions as she came on. Having come within a hundred yards or so, she changed her course and made off again. For an hour or two our courses gradually diverged, and then we lost sight of her, and once more we were alone upon the ocean.

And all the time no smallest sign of recognition was made on either side, no How-do-ye-do even, though we could have spoken across without the megaphone. We understood the incident, so did they. It appears that some signal which we were flying, to indicate a steam-vessel under sail alone, or vice versa, is very like a signal of distress. They mistook the signal and amiably came to our assist- 


\section{YARNS OF THE VOYAGE}

ance. Doubtless they were chagrined at their error ; but we-surely a courteous " Good-morning; thanks for your goodwill "would not have been amiss-but no, we went on our way unheeding. We are English, you know!

\section{LIFE ON A LINER}

\section{THE CRICKETER}

When the explorers do not accompany the vessel all the way, but go to the last port of call on liners (a practice which has points), the exciternent is of another kind than that experienced on the sailing vessel. But everybody knows what life on liners is like. Occasionally a little human nature shows itself even there. Here is a case.

One of our men was the best of good fellows, in ordinary life as free from offensive vanity as anybody. But he is a good cricketer and somebody has told him so, and he hasn't forgotten it. When he goes to the wicket there is a squaring of the shoulders and a suspicion of swagger, which shows that he thinks he is going to appear to advantage. One day a game was proposed.

The cricketer asked a fellow-passenger to join, one who was no cricketer, but an artist, and who had therefore been dubbed "putty," as that is supposed to be the principal medium of an artist's craft. Putty protested that he had never played. "Oh, you'll play," said the cricketer, with an air which said, "if you have anything of the man in you, you won't refuse to play cricket." Putty went 


\section{MEMORIES OF ANTARCTIC DAYS}

to bowl. You know what cricket is like on a liner, played between decks in a great cage, when the space between the decks is so limited that if you bowl overhand you knock your knuckles on the girders of the roof (or whatever they call the equivalent on board ship).

Putty's first ball struck the deck above-he tried again, and struck the side of the deckhouse. "Oh," says the cricketer, "I think you'd better stick to art, Putty!" Putty sent a third ball, and by chance bowled his man out. 
JACK ASHORE : PORTS OF CALL

\section{CHAPTER V}

\section{JACK ASHORE : PORTS OF CALL AND BETWEEN THE VOYAGES}

\section{NEW ZEALAND}

T HAVE never spoken to a man connected with any of the Antarctic Expeditions who was not in love with New Zealand. Most of us have had the time of our lives there. Where will you find such hospitable people, such a glorious, beautiful, and unspoilt country ?

The circumstances are auspicious. The people are enthusiastic about expeditions. You are heroes without having done anything. From the moment of arrival, when the reporters make their first onslaught, till you sail away, you are the object of constant attention. I have known the quietest and most modest of men (in everyday life) become so acclimatized to these attentions that they felt keenly disappointed if there were not several reporters and a brass band to meet them at every little place they visited. They get over this eventually.

You will never escape from the cities if you once allow yourselves to be enmeshed in the net of social attractions. And then the girls ! - there is no danger encountered on the whole expedition to be compared 


\section{MEMORIES OF ANTARCTIC DAYS}

with that you face when you run the gauntlet of the New Zealand girls. Many a good explorer has fallen there, but, to give the girls their due, the victims appear to go very willingly, and to be extremely wellpleased with themselves. One amiable young fellow that I know of got engaged to thirty-two girls, but of course he was fairly safe, and anyhow he has nobody to blame but himself.

Three of us, who did not feel too much at home in cities, shoved off quite early, and had a run round the islands, and by the way had one or two mild adventures.

We first made for the mountainous region of Mount Cook, setting out to walk from the railway terminus at Fairlie to the hostel on Lake Tekapo, a distance vaguely given as something over twenty miles. It was.

At a little wayside rest-house we had our first experience. As we stood at the-bar (two-thirds of the party were Scotch, and one-third was teetotal) we muttered the national incantation-Slainge mhor ("Good health" in Gaelic) as we raised our tumblers. We noticed a bearded head, visible through a small window leading to a neighbouring room, become suddenly excited on hearing the words; the head disappeared, and presently a figure burst into the room where we were, jabbering incomprehensible Gaelic. We had found a compatriot, who, hearing our toast (about all the Gaelic we knew), imagined we had the language.

When, after much trouble, we got him convinced that we could really converse more easily in English, 


\section{JACK ASHORE : PORTS OF CALL}

he resumed that tongue, not a bit less friendly for his disappointment, and we solemnly performed the national ceremonies proper to the occasion. Some time later we resumed our way, cheered by the encounter.

As we made our way wearily towards Burke's Pass, we learned that we were in a valley peopled by McMillans, Mackintoshes, Grants, and others of our nation. Bagpipes were skirling, and we remarked what a very Scotch region it was. Being then young and innocent, we never dreamed that the pipes skirled in our honour; never dreamt that our approach had been heralded.

It was a very hot day, and the way was much longer than we had been told, and we were very soft after a four months' voyage without exercise. We lunched at Burke's Pass and passed on. Day wore on to afternoon, to evening, as we trudged across the Mackenzie Plains, hour after hour, meeting nothing, seeing only rarely a distant "station" (or farm). Night fell, we got very tired and footsore.

There was no sign that we might be approaching the hostel, and as we knew that it was situated on a great lake, of which we saw nothing, we inferred it must still be a long way off; and still we were on the sandy plain, looking alike in every direction. It was late at night now, and we rested. The two younger men suggested pushing on, while I rested for a while longer.

They went off, and I rested, and nodded, and finally slept. I know not how long' I slept, when I woke refreshed, and looked about me before resuming the 


\section{MEMORIES OF ANTARCTIC DAYS}

road. Then I wondered which was the right way, for I had forgotten which side of the road we had rested on. I set out at random and by and by became aware of a familiar object ahead of me, the Constellation Orion, which had been in the same direction as we crossed the Plains.

Soon I met a boy leading a couple of horses, and learned that he had been sent to meet me. Somehow I scrambled on to the back of one horse, being perfectly stiff and footsore. I had never been on horseback in my life; it was very dark, and I could not find the stirrup. As I fumbled for it the horse turned its neck and looked in my face as much as to say, "What kind of thing is this I've got on my back?"

Then the boy cautioned me that the horse might bolt if I gave it the slightest accidental touch with the spur, and warned me to be careful I did not get hurt if he made for his stable. In the pitch darkness, when I couldn't see in the least where we were going, this was a needless complication of dangers, so I persuaded the boy to lead him the short distance to the hostel, and thus I made an undignified entry. It was plain the boy shared the horse's opinion of me.

Next day we proceeded by motor coach, and had no further adventures worth recording.

Later on the tour Dr. Michell and I made for the more primitive West Coast, crossing Arthur's Pass and making the alarming descent through the Otira Gorge by coach. About halfway across we lunched at a primitive inn, kept by simple, homely people. There we encountered a fellow-traveller, who de- 


\section{JACK ASHORE : PORTS OF CALL}

clared that he was "very fond of what he liked," and proved it by refusing helping after helping of the plain, good fare, till the little waiting-maid was open-eyed with astonishment, having evidently been so fortunate as never to encounter one of his kidney before.

We set out with two shirts apiece, intending to husband one in the hope of gaining entry to hotels by its influence. The first day's journey being from civilized Christchurch by rail, we started in all the glory of clean shirts, brushed clothes, and polished boots.

The New Zealand trains are built on the American plan. Doc. Michell was never happy on a train unless he travelled on the platform outside the coach. I shared his taste in this matter, and indeed there is no better way to see the country, and you get a fresh breeze, which is very grateful in hot weather.

We were travelling thus towards Broken River when, quite unexpectedly, the train plunged into a tunnel. We were so taken by surprise, we had no time to get inside the car. When we emerged from the tunnel our white shirts had turned into black ones.

We had now only one shirt apiece, which had to serve for ordinary wear and special occasions during nearly a fortnight of travel. We solved the difficulty for a time by wearing no shirts in ordinary times, but coloured handkerchiefs as stocks. We wore no vests, very shabby clothes, heavy hobnailed walking boots; and we carried shoulder bags and walking sticks. 
But we need not have feared being refused at West Coast hotels. There, strange to say, unlike many, many hotels of which I could tell you in all parts of the world, the host seemed pleased to have guests come in, even with muddy boots.

As the weather was bad while we were on that coast, and we made our excursions into the bush under these conditions, and took deck passages on coasting vessels, we soon became muddy, and travelstained, and untidy, and very disrespectable indeed.

People can't make us out. They know we are some sort of low-down fellows, but fail to place us. The native "bums" almost invariably wear bowler hats, however much battered. But we are not turned away from hotels, at least not till we reach the great cities.

After crossing the Otira River it came down in flood, and we could not return by that route if we wished it. We were very lightly equipped for walking, having each only the one shirt, a couple of collars and a few handkerchiefs. It rained continuously and in torrents all the time we stayed on the West Coast.

The only way out was by coasting steamer to Wellington. We were getting short of funds, so we went steerage. The sleeping quarter seemed to be right down in the bilge. As we made our way down the ladder we were met and stopped by a solid ascending column of stench. We slept on deck.

In Wellington we had to seek a cheap sailor's lodging-house, in order to husband our few remaining shillings till we should reach Auckland, 


\section{JACK ASHORE : PORTS OF CALL}

where there was hope of succour. We found one which announced: "Beds, 6d. each." The inside scared us. We went further and found, "Clean beds, 9d. each." We had one each, and they quite bore out the claims of the advertisement.

Next morning we had to have very early breakfast in order to catch the through train for New Plymouth. When we got down between five and six o'clock we found a man in chef's cap busily preparing ham and eggs, and between whiles conversing with the waiting guests through a little serving hatch. He was the proprietor, and evidently a facetious fellow.

When we came in an impatient guest was complaining of the delay in getting his breakfast. The chef informed him that "It's against all the Rules and Regulations of the Board of Arbitration to give you your breakfast before it is ready"; which, being translated, means that, labour being in some degree organized in New Zealand, there is some law to the effect that employees must not begin work before six o'clock a.m., and as that hour had not yet arrived, the proprietor had everything to do himself.

We learned from the Wellington newspapers that a baronet of our acquaintance was in town. The papers even told what hotel he was putting up at, but we did not call.

Next day we reached Ouehunga, the West Coast port for Auckland, possessed of the price of a shilling breakfast, of a telegram to headquarters for the needful, tram fares to Auckland, and one shilling more. 


\section{MEMORIES OF ANTARCTIC DAYS}

Hitherto it had been our custom to travel without wearing collars, only donning them when we had to show face at hotels. This scheme had now failed us, for we had no collars now in a condition to help us to greater respectability. We tried one hotel in Auckland, but were turned away with scorn. Something must be done. We couldn't both get collars and ties, so it was decided one should get these necessaries. The lot fell to me. I purchased the necessary articles and presented myself at another hotel, asking accommodation for two, while Michell skulked out of sight. It succeeded, we were admitted, and that phase ended. We returned to civilized life and hotel corridors.

In one town we visited we put up at a hotel in the principal square. The proprietor wasn't much in evidence in the hotel, which was run in the most irresponsible manner by four happy-go-lucky girls, who addressed one another by the diminutives Rosie, Jinny, Polly and Kitty, and shouted the most private matters to one another from the ends of the house.

We ordered breakfast for seven o'clock, and, not being called, went down at a quarter past seven. Jinny, the waitress, exclaims, "Goodness, are you two going early, too? Well, you can't have breakfast yet awhile. I've to take tea up to master and mistress in bed," and off she went. By 7.30 there were nine guests waiting for breakfast ordered for 7 o'clock, and intending to leave by trains from 7.45 to 8.20 .

Jinny returns and begins serving, shouting orders 68 
down the dumb waiter to Kitty below. Kitty's voice is heard in a whisper audible to all-" Jinny, dear, have you five minutes to spare?" "Well, love," answers Jinny, "I've nine breakfasts waiting." Kitty, "Oh, you must." Jinny, "Well, dear, I'm listening, what is it ?"

Then Kitty related a wonderful dream she had had last night, in great detail, of which we heard scraps. The guests for the 7.45 resigned themselves to eatch the next train at 10.15. The tale ended, "And he shot you, and then he shot me."

Then Jinny deigned to serve us.

The lesser hotels of New Zealand have a pleasing simplicity about them which is very refreshing after experiencing the strictly impersonal management of our hotels. The proprietor is the "host," and takes the head of the table (the common table); the serving-maid serves the guests, then sits down herself with them.

It is reminiscent of the times when hotels were guest-houses, and the proprietor was mine host, and we had not yet sunk to such stupid slavery to class distinctions as characterizes the present age.

\section{THE LAST DAYS IN NEW ZEALAND}

There are no pleasant recollections of the last days on shore. All the ceremonial farewell dinners and pleasant social functions are over. It is all one frenzied rush of preparation for the voyage, obtaining important necessaries forgotten before, selecting everything that could possibly be left behind. The 


\section{MEMORIES OF ANTARCTIC DAYS}

weather is frightfully hot and you are perpetually bathed in sweat.

It is the New Year holiday season; shops are closed, and it is difficult to get anything you need to buy. I required some very fine needles and thread for making fine collecting nets. The two or three drapers' shops into which I was privately introduced had nothing fine enough. At last the wife of our hotel proprietor came to the rescue and supplied the want from her work-basket.

The last night we sat up all night and packed, at least all in our hotel did. One lot of stuff was packed to go aboard, another to be left behind. After every available receptacle, including sailors' kit-bags and pillow-cases, had been packed, my room remained a chaos, but it was all within my own borders. It was order itself compared with that of one of my companions, who had not my genius for packing. After he had finished, the surplus overflowed and filled a large sitting-room which had been put at his disposal.

Valuables were scattered about among the debris. The hotel-keeper brought me a paper he had picked up, asking if it was of any value. It was his doctor's diploma, or whatever certifies that he is a doctor. 


\section{THE SOUTHWARD VOYAGE}

\section{CHAPTER VI}

\section{THE VOYAGE TO THE SOUTHWARD}

\section{GOOD-BYE TO NEW ZEALAND}

T T was broiling hot on New Year's Day, 1908, on which we were to depart for the South.

It was the day of the great summer regatta, and great crowds were expected at Lyttelton. The crowds came, and we were at liberty to believe they had come partly in our honour.

Lyttelton station, where there is a level-crossing from the main street to the harbour, looked like a country fair. There were shows, merry-go-rounds, brass bands; booths were set up in every direction, among the lines of rails, and the people were massed everywhere, apparently regardless of the fact that trains were due from Christchurch every few minutes. A train comes out of the tunnel and enters the station. Immediately rows of men lift ropes placed there for the purpose and make of themselves a living fence on each side of the line till the train has passed.

Going down from the hotel to go aboard the Nimrod, I find the crowd so dense that I have difficulty in fighting my way through it, and take a long time to reach the ship. I don't know where 


\section{MEMORIES OF ANTARCTIC DAYS}

any of the other fellows are or what anybody is doing.

A mail has come in that morning, and has been eagerly awaited, as it is the last we may expect for more than a year, but for some of us it has brought nothing. I suppose friends, in their anxiety not to miss the last chance of writing, posted their letters in good time, and they all came a week ago.

In the midst of the crowd I come across two friends who are trying to get near the ships to see us off. We struggle along together and at last reach the Nimrod.

Amidst demonstrations of good-will from the people and friendly hootings from the ships in the harbour, we pass down to the heads, where the last of the tugs leaves us and we have the Southern Ocean to ourselves, save for the towing ship.

It is a calm evening, with a ruddy sunset behind distant snowy mountains, as we look our last upon the land. The only birds in sight are the whitefringed southern gulls and occasionally a cormorant.

Next day, January 2, the shore birds had all disappeared, and the oceanic albatrosses were already circling round. It rains, and blows, and the ship pitches and rolls, and the novices begin to be very unhappy. One of them voiced the general feeling in quoting the saying, "God doesn't love me, and my skin doesn't fit."

I help Day to get the dogs up on to the bridge deck. He passes up their chains to me, I pull them up, and soon I am the centre of a writhing mass, their chains tied up in inextricable knots. 


\section{THE SOUTHWARD VOYAGE}

In the afternoon the bridge deck was covered with prostrate men and dogs, basking in the sun.

The sleeping quarters of the members of the landing party have been named Oyster Alley, and the name strikes us as appropriate, though I can't tell why. It is only a bit of the hold separated off, and a very small bit; there is almost no light, and no ventilation at all. Seventeen Scientists (euphemism for members of landing party) are to sleep down there.

Some time after retiring to sleep in Oyster Alley, I awoke gasping for breath, and scrambled desperately towards fresh air on deck. There are supposed ventilators for Oyster Alley on deck, but, with the perversity which always attends such things on ships, they are invariably turned the wrong way. A thick, warm steam could be felt slowly oozing up the ventilator-you could warm your hands at it, but it did not ooze fast enough to admit any appreciable quantity of fresh air.

After this suffocating experience I slept in various nooks and crannies about the ship, but never again in Oyster Alley.

The first night I tried the wardroom. It was very small, but there was a bench along each side of the table, too narrow for comfort, but in such a confined space it seemed scarcely possible to fall off. Somebody was already on one bench-I got my blankets and stretched myself out on the other.

The ship was rolling, and seas were coming aboard, now and again even into the wardroom, where the water splashed about a while before leaking through and dripping down on the bunks of the sufferers in 


\section{MEMORIES OF ANTARCTIC DAYS}

Oyster Alley. After rolling off once or twice into the water on the floor, blankets were of little further use for the giving of warmth.

Shivering with cold, I got up to stretch my legs on deck. I noticed that the occupant of the other bench had gone. A sea came aboard just as I went out, and I immediately noticed a geologist washing about in the scuppers, quite indifferent whether he went overboard or stayed on the ship.

These were only the mild beginnings of our miseries, for the bad weather which now began lasted till the tenth day out. Nobody knew very much what anybody else was doing, or cared, but at the worst of times a few survivors always gathered together at feeding time. And there was always something to eat, for, in spite of great seas putting the galley fire out, the cook and the steward never failed us.

We were perpetually wet. The leaky deck rained down on those in Oyster Alley. On deck you were sure to get caught by a sea any time you moved from one place to another. There was no question of changing the wet clothes for dry. It couldn't be done, and, if it could, it would have availed nothing. It was cold and raw, and the light clothing we had put on for the tropical heat of a New Zealand summer had to serve unchanged week after week till it eventually went to pieces on our bodies.

The pumps were going continually, but the water at one time rose till it flooded the stokehold and threatened to put out the boiler fires. A venerable Scientist could have been seen, up to the waist in water, pumping like mad. 


\section{THE SOUTHWARD VOYAGE}

Seas carried away the bulwarks at both sides forward, and even part of the rail of the bridge deck. On the ninth day out the storm was at its worst. The pony watch was given up-it was too dangerous to the watchers. One of the ponies had been shot, and a dog died from exposure. There was a general feeling of discouragement, largely due to exhaustion from want of sleep.

Then, on January 10, came calm after the storm, and we got some rest and cheered up, and showed it by a gramophone concert and sing-song.

With renewals of the stormy weather, and an occasional fine day when we could lie and bask in the sun, the voyage dragged on till the $14 \mathrm{th}$, when we encountered the first iceberg, a fine, large, old one, of sugary whiteness in the sunshine, with turrets, pinnacles, and arches.

On January 15 the towing ship left us and we broke the last link with the world.

We passed through a great stream of flat-topped bergs, open enough to allow of steaming full-speed, and saw the first seals and penguins on some of the low cakes of ice. Soon we crossed the Antarctic Circle, and a day or two later saw the midnight sun. For a week, from January 16 to January 23, we steamed south through open sea, and at last sighted the Great Ice Barrier, which stops our progress to the southward.

January 24.-Skirting the Barrier eastward, towards midnight we entered an ethereal scene. The sea was like glass, and the sun just peeped over the edge of the barrier. The great cliff ended, and a 


\section{MEMORIES OF ANTARCTIC DAYS}

wide bay opened out, stretching far to the south, bounded by a long line of bergs, on which the sun shone, and which, raised by mirage, looked like a great city of marble palaces floating between sea and sky. It is cold, and so still that ice flowers are beginning to form on the sea.

A party of stately Emperor Penguins is disporting on some fast ice. Many brown Skua Gulls are flying about. The sea is alive with whales; might without exaggeration be said to boil with them, so quickly are they rising to blow in every direction. Many kinds are distinguished-Killers, Finners, Humpbacks, Bottle-nose, and some we can put no name on.

Everything suggests a superabundant feeding ground here, and, somehow, the neighbourhood of land. The spot might well be called the Bay of Whales-on every side great Finners spouting, hundreds of them, steam rising twenty feet or more; Killers (the largest of the Dolphins), twenty or thirty feet or more in length, roll over porpoise fashion, giving one loud sigh as they do so.

Flocks of snow-white and chocolate and white Petrels, thousands of dusky skuas, fly about.

Years after, on reading these notes, I suspected that possibly in the exaltation of looking on such a marvellous scene, I might have painted in too glowing colours the exuberance of life. I was reassured on seeing Captain Amundsen's kinematograph films of this very Bay of Whales. He appears to have found them even in denser crowds than we did.

January 25.- Still eastward along the Barrier, 76 


\section{THE SOUTHWARD VOYAGE}

trying to reach King Edward Land, till finally stopped by impenetrable pack.

We are in nearly 79 degrees of South Latitudethere is between 10 and 20 degrees (Fahr.) of frost, and yet it is so still it is possible to lie about on deck, writing letters with bare fingers, and it is hot.

Some biological work was attempted on the southward voyage. For a long time nothing could be done but watch the various kinds of birds that came along, and try to fathom the skill of the Albatross, which by gliding alone can go in the teeth of the gale, and at a great pace.

For fishing with nets in the sea a long boom would be necessary to try to keep the nets clear of the wash of every kind of dirt which perpetually streamed from a ship crowded with men, horses, dogs, cooks and engines. This boom was refused me for a long time, no doubt for the usual obscure "reasons connected with navigation," which are made an excuse for so much privation.

At length the bos'n was allowed to rig me up a boom, for which an oar of a whaleboat served. The boom was only partially successful - that is to say, it sometimes cleared the dirt and sometimes didn't. On one occasion I caught in the net a great beetle, of a kind I had previously got in New Zealand. I naturally thought my first specimen had been accidentally tumbled into the net before the fishingbut no! the beetle was safe in its bottle. We concluded that the second one had come in the horsefodder and had been thrown overboard at exactly the right moment to be caught again. 


\section{MEMORIES OF ANTARCTIC DAYS}

On another occasion I had the nets out, and had caught-well, a great deal of the sort of thing I didn't want. I was gazing in disgust on my catch when a certain eminent Scientist, noted for his excess of politeness, came up to me and said in his suavest manner, "Well, Murray, I do so hope you have got a fine lot of nice specimens." "Oh, yes, professor" (showing him the contents of the net), "if you call these fine specimens."

The colour of the sea varied greatly and suddenly. Some tracts were clear, slaty blue-the usual sea colour-others were yellow and turbid, like soup. The colour of the turbid sea was caused by myriads of spiny microscopic plants, called Diatoms. There was usually little else in the nets, till we got into Macmurdo Sound, when the collections became rich and varied, containing sea-butterflies and shrimps of a rich red colour, and lots of other nameless beauties which we had not seen since we left sub-tropical seas.

As is known, we found it impossible to reach King Edward Seventh Land, and, after several attempts to penetrate the dense pack at different places, we turned unwillingly westward. Passing again through the Bay of Whales, which we found, as before, alive with the animals, we traced the course of the Barrier for some distance, then kept further out to sea, losing sight of the great ice wall, but still seeing its ice blink, until on January 28 we first sighted undoubted Antarctic land, Mount Terror looming up in the west. 



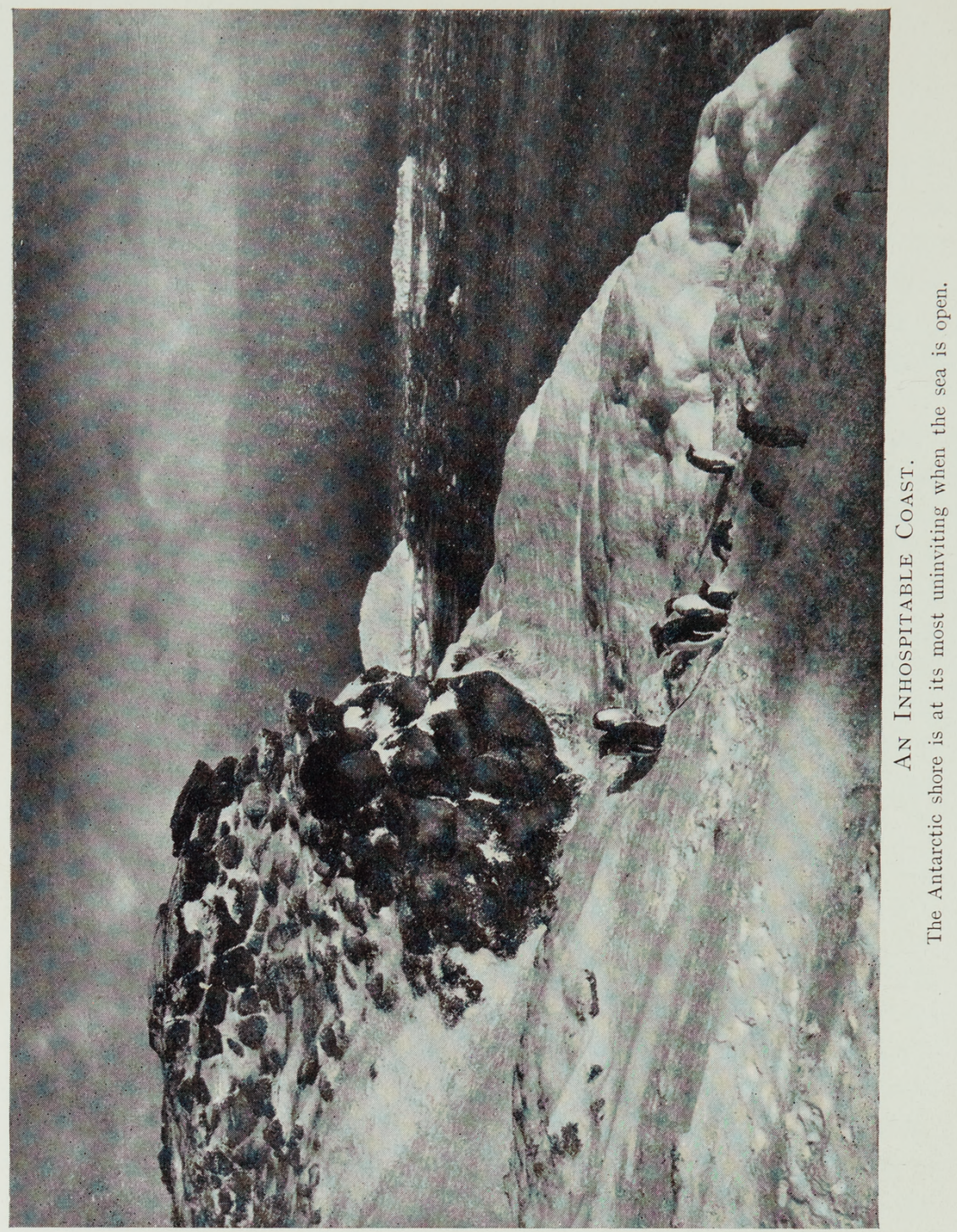




\section{THE ANTARCTIC}

\section{CHAPTER VII}

\section{THE ANTARCTIC}

FTER a very uncomfortable voyage of more than a month, of which there has been more of the doleful than of the humorous to relate, we steamed into Macmurdo Sound, and made fast to the old ice there, at no great distance off Cape Barne and Inaccessible Island.

Again it was several days before we could make a landing, and we lay moored to the edge of the rotten fast ice, striking up a first acquaintance with Penguins, and Seals, and Skua Gulls.

On February 3 we landed at the spot which was to be our home during our stay in the Antarctic, Cape Royds.

\section{A TOPSY-TURVY LAND}

South Victoria Land is a magnificent country, Switzerland with its Alps on the sea shore, grand peaks and mountain ranges rising right from the sea to heights of 13,000 feet.

It is a land of paradoxes-one of the most inhospitable regions of the world, notorious for its blizzards; yet where thunder is unknown and it 


\section{MEMORIES OF ANTARCTIC DAYS}

never rains. You feel the cold least when it is greatest, on account of the dryness of the air.

In the hottest summer weather the temperature of the air in the shade just comes up to freezing point, yet it feels oppressively hot, so that we went about clad only in pyjamas, and if the air was still it was possible to sleep on the ground in the open air at midnight. But then at midnight the sun was shining brightly in the South.

Summer is the snowy season, the season of the heaviest snows at any rate-it is too cold for snow in winter. The winter blizzards fill the air with snow, but little snow falls. In this, the supposed very home of ice and snow, the snowfall is very small, and many of the glaciers are receding or dead.

You steer northerly by the compass to reach the South Pole.

The temperature of the sea-water is all the year round several degrees lower than the freezing point of fresh water, yet the growth of animal life is so vigorous that at moderate depths the entire bottom is covered and hidden under a dense carpet of rooted animals, and among these hunt and grub great numbers of active and predaceous fish and other locomotive animals. And all the time the temperature of their bodies is just about that of the water in which they live ; that is to say, they are below freezing point, a temperature which has been supposed to be fatal to all life.

On the land, too, and in the lakes, there are found myriads of the most minute and delicately formed animals, quite invisible to the naked eye, yet aggre- 


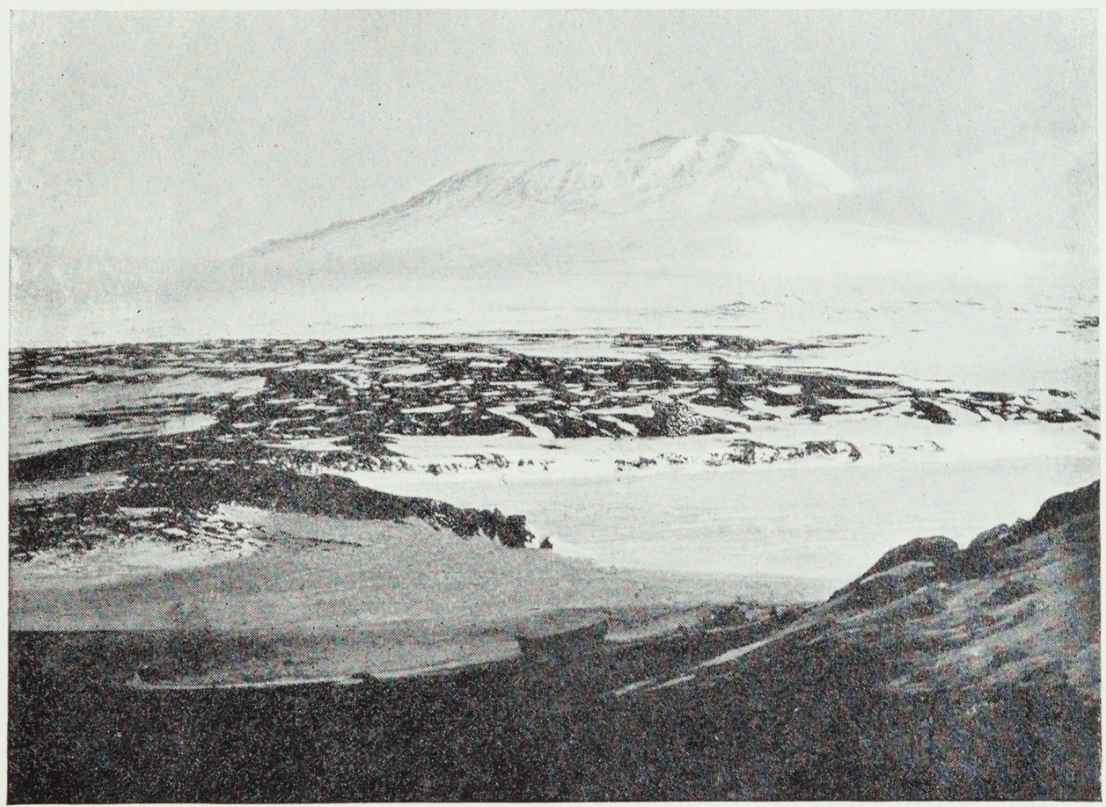

Photo by J. Murray.

An Antarctic Landscape- “ The Ruined City of Erebus.” The appearance of ruined streets is caused by the dark moraines, intersected by gullies filled with snow. 

gated in such vast hordes that they form large patches, like blood, on the stones. And these delicate, softbodied creatures cannot be killed by cold. When the water in which they live freezes, they may be frozen solid, their very blood frozen, and they may remain thus for many years, but always alive and ready at a moment's notice to resume feeding whenever the ice melts.

One of the Penguins, the Emperor, breeds in the middle of winter, in the coldest season of the year, when it is dark, and on the sea ice; and it makes no nest at all, but carries the egg on the top of its feet, and, thus burdened, shuffles about.

The Antarctic material has been distributed through half a dozen chapters, dealing with "Sledging," "Animal Life," the Aurora Australis, etc., etc., leaving nothing more for this introductory Antarctic chapter but one incident illustrating the disagreeable side of life in that region. The experience was not really so serious as such a blizzard would have been on a long sledging journey, but it was decidedly unpleasant.

\section{IN A BLIZZARD ON MOUNT EREBUS}

Before leaving for the South, our chief had arranged that a geological reconnaissance should be made, with the object of allowing our geologist, Priestley, to examine the oldest crater of Mount Erebus. Owing to persistent threatenings of bad weather, which never came to anything, the start was put off day after day till November 23, 1908, when no further 


\section{MEMORIES OF ANTARCTIC DAYS}

delay was possible if the journey were to be made at all, as it had been arranged that Priestley should accompany Armitage's depôt-laying party to the west on December 1.

On Monday, 23rd, then, we set out, in fair weather, but with serious misgivings about the overdue blizzard. The party consisted of Joyce, Brocklehurst, Marston, Priestley, and myself. Armitage went with us for the first day.

It was heavy going uphill over soft snow and thinly-covered moraines. When the footsteps are no more than the length of the foot it is very exhausting work. After a heavy day's march we estimated we had only made about five miles and reached an altitude of between 2,000 and 3,000 feet.

We could find no very suitable camping ground, but at last chose a place beside a picturesque " nunatak," with huge black cliffs towering above us. The ground was sloping somewhat steeply and was covered with snow, but on setting up the tent we found that it was blue glacier ice, covered with only an inch or two of snow. It was not an ideal spot for a permanent camp, but for one night it might do, and besides we had no choice. Armitage had gone back. It was a calm and beautiful night, and as we scrambled about among the intricacies of the rocks, gathering the many forms of lichens which grew there, we had no misgivings, and little suspected that it was to be the first and last camp of that journey.

We turned into our sleeping-bags early, being tired. The tent only held four men, packed like herrings in a barrel, heads and tails alternately. Priest- 


\section{THE ANTARCTIC}

ley had elected to be odd man out, and had placed his sleeping-bag in a crevice of the rocks far above us.

Towards the middle of the night I was awakened by a great row. The blizzard had arrived; the snow had been blown off the tent bottom and the tent was flapping dangerously. We all scrambled out to the rescue. The glacier had been swept clean of snow, and we had to bring rocks which had tumbled from the "nunatak" to weight the tent. In our smooth finnskoe it was a serious undertaking crossing the few yards of treacherous surface, and we staggered, slipped, and fell, as we brought the rocks over.

At length the tent was safe, and we crowded into it out of the stinging, driving snow. We had been anxious about Priestley, sleeping so far from us, but he had noticed the blizzard earlier than we did, and we found him in his sleeping-bag, lying a yard or two below the door of the tent.

This was on Monday. During Tuesday and Wednesday it raged without ever a lull. The air was full of driving snow and you could not see a yard through it. It was impossible to get the cooking stove from the sledge, though that was only two or three yards away. Now and again we opened the door-flap for a second and hailed Priestley, who reassured us by his "All's well." We had some cold pemmican and a few biscuits. Most of us were unable to eat the raw pemmican, but to me it tasted as good as plum pludding. The floor-cloth had preserved a layer of snow of its own area, and this supplied us with drink. Despite all that has been 83 


\section{MEMORIES OF ANTARCTIC DAYS}

written against it, snow makes an excellent drink, when ice cannot be had, if you first compress it in the hand till it begins to melt.

On Thursday the blizzard still raged as fiercely as ever. We hailed Priestley and got no reply. With the gloomiest forebodings, Joyce and I drew on our ski boots and went out. We thought of Priestley sliding down the glacier to where it ended in icecliffs going sheer into the sea, only a few hundreds of yards below us.

As soon as we stepped outside the tent, the snow drove in our faces, quickly forming a sheet of ice over our eyes. It was impossible to stand. We dropped on our hands and knees and made our way down hill, immediately losing one another. I soon came to the sledge and knew from its position where Priestley had lain. He was not there. I groped on a few yards, but did not come across him. Just then a shout from Joyce, who had gone further to the right, told that he had found Priestley, and that he was alive. He had had neither food nor drink in the three days. Joyce passed some food in to him, and we tried to regain the tent. That was not easy, though it was only a few yards away. It was quite lost to view; we had to go with our heads bent down for shelter from the drift; the only guide was the direction of the wind. I went past the tent, but came on an ice-pick stuck in the glacier, from which I found its position. We got in the shelter of it, thawed the ice plates off our eyes, and went inside.

Priestley had suffered severely from thirst. He had tried in vain to pick off some fragments of ice 


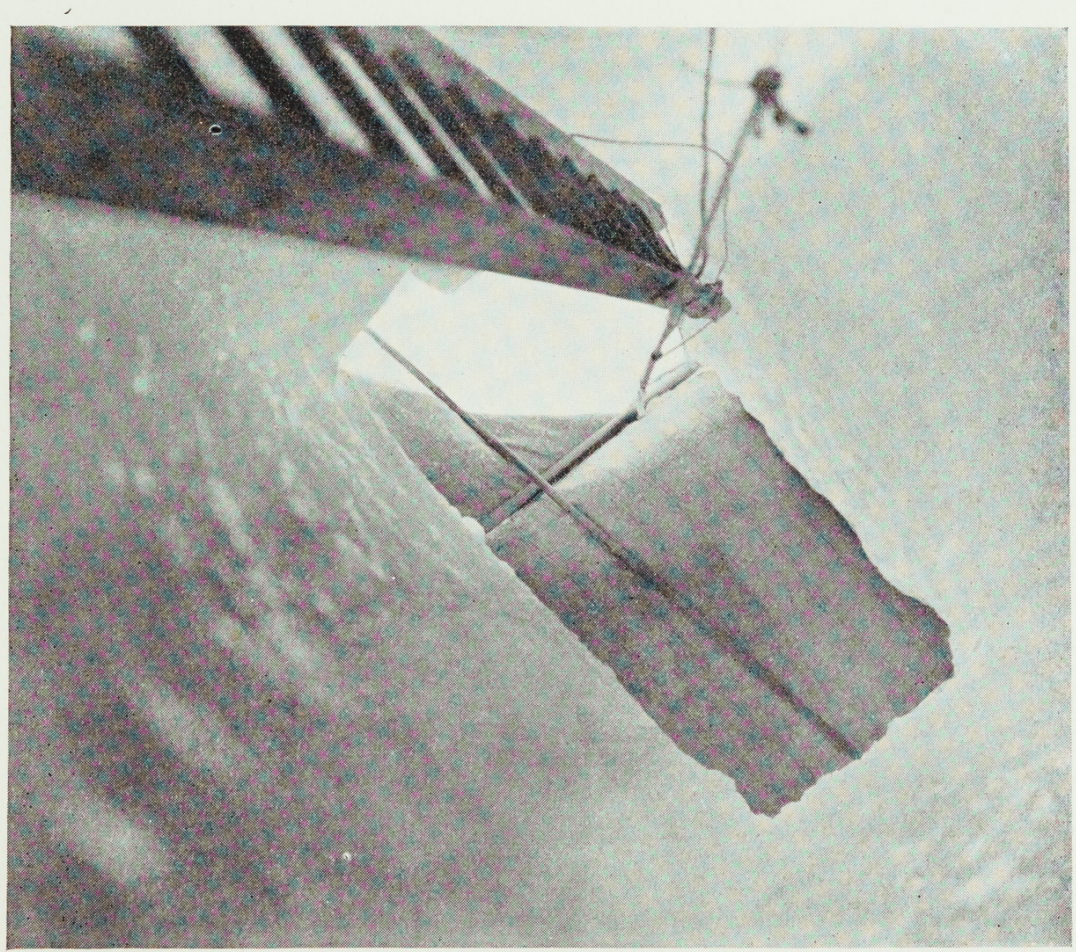

A Curious Photograph.

Looking vertically upward from the bottom of an ice-shaft, twenty-one feet deep, cut in Blue Lake. 


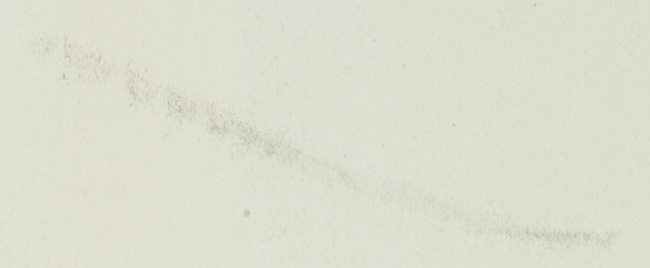




\section{THE ANTARCTIC}

with a pin. As he turned in his sleeping-bag, it gradually slid further and further down the glacier.

On Thursday evening there came the first break in the blizzard. The wind continued almost as strong as ever, but the drifting snow ceased. The hillside must have been swept clear of soft snow and there was no fresh snow falling. Fearing a renewal of the blizzard, Marston went out and helped Priestley up to the tent, where he lay across the others, there being no available space otherwise. His feet were frozen, and Marston spent a long time restoring them.

We had taken the opportunity afforded by the lull to bring in the Primus and cooker, and about midnight we tried amid great difficulties to make a hoosh. There were five men squeezed into a three-man tent. At last the hoosh was ready, and we eagerly attacked it, only to have a bitter disappointment. Paraffin had got into the pemmican, and the hoosh made us all feel sick.

There came a renewal of the blizzard for a few hours, but at 4 a.m. on Friday the wind slackened, and we hurriedly struck camp. There was considerable delay before the sledge was ready, as one and another got frost-bitten feet, no doubt because of our reduced condition from lack of food.

When we at last got started everybody was more or less weak from lack of food and inclined to be sick from the paraffin we had taken in the hoosh. Before lunch time we were in the hut, from which we had never been further than an easy walk, if the weather had been clear. 


\section{MEMORIES OF ANTARCTIC DAYS}

\section{CHAPTER VIII}

\section{FIRST IMPRESSIONS OF SLEDGING}

\section{By G. E. Marston}

$7 \mathrm{HE}$ romantic is doubtless one of the forces drawing people to the waste lands of the

1 earth, and sledge journeys over vast snowy plains into unexplored regions will always exert a magnetic influence over human beings. The fascination of such a life is hard to explain; you give up all the little luxuries you have been trained to regard as necessities, and live in a manner almost as comfortless as the lives of those human waifs haunting the doorways, embankments, and odd corners of any great city. Still there is some substratum of pleasure, of which you are conscious, but perhaps cannot define. My own experience of sledging during the Antarctic spring of 1908 has left distinct recollections of many physical discomforts suffered, but a strong desire to do it again.

In attempting to answer that oft-repeated question, "What is it like?" I offer you the first impressions of a novice, in the hope that they will prove of some interest to those who feel the attractions of the silent corners of the earth.

The Antarctic winter is past-those four months of darkness which to men less fortunately situated 


\section{FIRST IMPRESSIONS OF SLEDGING}

than ourselves have proved months of gloomy horror, were to us, with a comfortable hut, plenty of food and cheerful companions, a time of pleasure, when one was free to enjoy the beauties of that long night, and appreciate to the full the care-free conditions of life in a country where civilization has not introduced innumerable complications. During that time we had devoted our energies towards preparing for the sledge work which was to begin with the return of the sun. It is of this one talks all the winter, and I would say, dreams, only truth compels me to confess that the evidence of the various night-watchmen in the hut, gathered from the uneasy mutterings of the sleepers, would contradict me; but still we talked, and aired our unfledged views, and prepared our gear.

On the return of the sun, short depôt-laying journeys were made, which from their shortness of duration were, in spite of the cold, of the nature of picnics, but now the word is passed that a depôt is to be laid well on the southern route. This is more serious work, and we carefully overhauled our gear, calculated and weighed food supplies to the minutest detail.

The party was made up, sledges packed, we had our farewell dinner and prepared to start in the morning. Morning came, and with it a blizzard. We waited till the next day, and left in a low drift. Day helped us with his car over the first few miles of sea ice. He left us, and we settled down to the drudgery of hauling one thousand pounds of food and gear. Soon we were aware that four pups 


\section{MEMORIES OF ANTARCTIC DAYS}

had followed us, these we drove back and proceeded, only to find a few miles further on that they were with us again. Joyce, who had had charge of their training during the winter, was one of the party, and never before had they been ordered to leave him. They retreated a few yards, sat down and listened attentively to all he had to say, and then followed us again. It was of no avail, they are sure to go back soon, we thought ; but no, next morning there they were patiently waiting at our tent door. This was embarrassing, we could not feed four hungry pups, and if they insisted on following us, the chances were they would have to feed us. There was one other solution possible, we were near Captain Scott's old hut, left there in 1901. In it was a plentiful supply of dog biscuits and snow which could serve as drink. We took them, all unsuspecting, shut them in and left them, vigorously protesting, to await our return.

We have rounded Cape Armytage and the Great Ice Barrier is in sight. Up a gentle slope, and over a tide crack, and we set foot on the barrier, some of us for the first time. This, no doubt, should have been a thrilling moment, but it wasn't, sledging leaves no time for exalted thoughts. Pulling, you are uncomfortably hot, resting, you are uncomfortably cold. Always, you are hungry. Ahead is the barrier surface, stretching away to the horizon, an unbroken plain of snow with nothing to break its monotonous uniformity. Nothing more deadly dull or uninteresting could be imagined, and yet it was there that all our hopes were centred. 


\section{FIRST IMPRESSIONS OF SLEDGING}

The temperature is now rapidly falling, for we are leaving the warm sea behind. We make a good march that day, for the surface is like polished marble, and nearly as hard. We turn into our bags at night with feelings of pleasure, we are warm and comfortable. How often have I seen people at home plunge their hands into the thick soft fur of these selfsame sleeping-bags and say, "That's all right, anyhow, you couldn't be cold in that." Neither were we. But then they were dry, and therein lies the secret of sledging comfort. Find a way of keeping the sleeping-bag dry, and you could defy any cold,-but how to do it. Snow creeps in in minute quantities be you never so careful, and, owing to the fact that three men are sleeping in one bag with the cover drawn over their heads and closely " toggled" down, all the moisture from their breathing is condensed and frozen on to the fur, snow and ice accumulate until, in perhaps a fortnight, the bag has doubled its weight. You turn in, and the heat from your bodies thaws the accumulated ice, and drip, drip, drip, it drops on your clothing, soaking you to the skin, setting you shivering and shuddering for the rest of the night. It is exhausting, and the short intervals of rest you do get you are unconscious of.

We are marching now in brilliant sunshine. There is little or no wind, work is a pleasure, and one feels so healthy that the mere fact of living is an intense pleasure. But around us is that wonderful silence, and that curious feeling of expectation, of waiting and listening. A puff of wind, a few 


\section{MEMORIES OF ANTARCTIC DAYS}

flakes of snow, and we know that the whole aspect of life will be changed for us, so we revel in the sunlight and enjoy it while we have it. We are abreast of White Island. We camp, and before morning there is a blizzard blowing. "Too thick for travelling," came from the other tent. "Go on half rations while it lasts." We eat a little, sleep a little, talk a little, and that day passes.

Next day the weather is worse. A few friendly shouts from the other tent, and we settle down to another day in our bags. We have accumulated a sort of moist heat which is fairly somfortable. When meal-time comes round we take it in turn to get out and prepare the "Hoosh," while the other two men make themselves as small as possible. The cook crawls out wet and warm, and immediately his outer garments freeze stiff. He gets frostbitten, thaws himself, gets frost-bitten again, curses it, lights the Primus stove; it won't go; curses that and everything else.

The other two men "lie low and say nuffin." They have had some, and their turn is coming. At last the cook passes round the steaming mugs of pemmican, jumps into the bag, and we all sit up and shiver and eat. Gradually faces relax, tempers improve, tongues loosen, and we put down our empty mugs, snuggle down into our bags, pipes are lighted, and we feel happy. To-day the yarns are more leisurely, we even manage a few songs. But we are warned that the weather is clearing, so get to sleep while we can.

We have been there three days before we can 90 


\section{FIRST IMPRESSIONS OF SLEDGING}

move, and now we must make up the lost time. It is fine weather again, and the marches are forced a little, but one day is very like another. All day the soft crunch, crunch, of our fur-clad feet in the snow to the accompaniment of the slee-e-e-e of the sledge runners, the steady pull on the traces, and the five minutes' rest every hour, during which you crawl under the lee of sledges, and pull out from your shirt your little bag of scraps saved from your meals, lumps of sugar, scraps of biscuit, crumbs of chocolate-dainty little scraps, to be eaten with the tips of the fingers or you may lose them. But they serve as a sop to your hunger. The rest over, you rise and discover you are stiff from head to heel. Each man hobbles to his place in the traces, painfully puts on his harness, and five minutes later no trace of stiffness remains. $\mathrm{He}$ is perspiring but comfortable.

Our discomforts now begin to multiply, our feet need constant attention. They are sore and blistered from travelling over hard, knife-like ridges in the snow. We keep four pairs of socks in use. Our efforts to keep a dry pair have failed, so now we confine our attention to keeping those not in use warm and thawed inside our shirts, so making one part uncomfortable to keep another in comfort. Our boots of untanned reindeer skin have become during the day moist, flabby bags of skin. At night, when we take them off, we shape them up into some semblance of a boot, and hope they will preserve that shape till morning. But alas! many a boot so carefully shaped at night is found in the morning a solid 


\section{MEMORIES OF ANTARCTIC DAYS}

flattened mass of frozen skin, which the owner has to thaw out as best he can with the little warmth left in his sore and tender feet, and then for some time to hobble on icy ridges of skin, until the work of pulling in the traces produces its accustomed comfort.

Our fingers, frequently frost-bitten, are now blistered at the ends, and strapping gear to the sledges is now a sore task. In the tent you take your mitts off to feed; they freeze, and you tuck your hands further up your half-mitts to keep them warm. They freeze, so that you can hardly get your hands out. There is no relief from the cold, no dodging it. You must never take your attention off it for an instant, or it will play you some mean trick. Look well after your gear, and think ahead. These at the most are only physical discomforts, but it is the little things that matter-they give you so little time to think of anything else.

Another blizzard, two days this time, but we are not sorry for the rest, even though it means less food. Without work, this does not so much matter. Our bags are wetter than ever, and after the first day we lie literally in pools of water, thawed out by the heat of our bodies. We pass the time as well as we can, glad of the rest, glad to get back to work, when the order comes to "Down tents and pack sledges."

Wild and Joyce (my tent mates) both know the country here from their previous experience in 1901. From them I learn that we may expect to meet heavily-crevassed country further on, and am 


\section{FIRST IMPRESSIONS OF SLEDGING}

given hair-raising descriptions of what crevasses are like. I, who have never seen one, am full of curiosity, but also learn to respect them. Sure enough next morning we see on the horizon a mirage of what looks like huge cliffs. Wild tells me these are the crevasses. Midday, and we are having one of our five minute spells. I am talking to one of the party, when I am startled by his sudden disappearance. I look down, and only his head and arms are visible. He has been standing on a "snowlid," and punctured it, slipped through, and saved himself by spreading out his arms. Before I recover from the surprise, I feel the earth slip from under me. I am falling, but grab a sledge, and only go down as far as my waist. We both crawl out and very gingerly step on to what we hope is solid ground, leaving two round holes showing intensely blue against the surrounding white surface.

The march is resumed and soon the surface changes in character. Occasionally we pass over what is practically blue ice, with small cracks here and there. Then right in our path a huge crevasse stretches as far as one can see on either hand, and as wide as Regent Street. It is hopeless to attempt to dodge it. It has a snow-lid, and, remembering Wild's descriptions of these lids and how they are formed by the snow, I cannot help wondering will it bear.

It has a droop in the centre, and the weight of two sledges and six men will surely test it to its utmost. I feel confident that we shall stop and 


\section{MEMORIES OF ANTARCTIC DAYS}

discuss ways and means of crossing it. But no, in silence our leaders step on to that awful bridge, and as I follow I mentally bid good-bye to everything. I have an unpleasant feeling which I must confess is fear and nothing else. I find myself trying to tread lightly and tenderly on that frail lid, and notice that other feet are doing the same. It is silly, but involuntary. Six feet from the other side and almost in safety, one man breaks through, throws himself forward and crawls out. Now we are on firm snow once more, and experience a feeling of pleasure at being able to plant our feet firmly on hard ground, and it is not until we have passed over several similar crevasses that I discover that these are not hollow crevasses at all, but old ones filled in, with narrow cracks on either side. They are safe enough to build a house onbut then, some of us didn't know.

Later on we are in a perfect maze of them, big and small, and falling through becomes a commonplace. Looking down them you see a deep chasm with usually upright walls lighted by an azure blue light, filtered through the snow, deepening down below to absolute blackness. No bottom can be seen. No flat surface now, hills and valleys, cliffs and chasms, tumbled together pell-mell, a hard icy surface on which the sledges slip and slide, making it necessary for two of us to remain by them to keep them on their course. A trying task, and when a runaway sledge overrides your softly-clad feet, it's no good cursing the silly thing, but you feel your temper getting ragged. We camp amid 


\section{FIRST IMPRESSIONS OF SLEDGING}

the scene in beautiful sunny weather. It is a scene of imposing grandeur. However, we have not come here to admire nature, but to lay a depôt, so look anxiously for a path out of such grandeur, back on to our old flat barrier surface, where our sledge metre will tick off a steady ten or fifteen miles a day, and where a straight course can be kept. Eventually we left it as suddenly as we entered it.

We try all sorts of experiments to dry our gear, and on sunny days hang out our bags and spare clothes, hoping that some of the ice on them will disappear and, although the temperature is somewhere about twenty degrees below zero, some of it certainly does go somehow. We now look like old clo' dealers, for the sledges are covered with hanging odds and ends of clothing.

I lost my sleeping-jersey this way. Probably I had tied it on with what the sailors among us scornfully refer to as a "Northampton hitch," but the fact remains that, in one of our five-minute spells, I discovered to my horror that it had disappeared. I asked for and obtained permission to go back on our tracks, in the hope of finding it, and started off on a steady jog trot, scanning carefully the ground we had covered in the hope of seeing that little black speck somewhere, the finding or losing of which meant comfort or misery at night for me on the remainder of this trip; but no, the hope was a vain one, everywhere the same dead white surface; the jersey must have blown off much further back, but I could not make up my mind 


\section{MEMORIES OF ANTARCTIC DAYS}

when to turn again-just a little further, I thought, and $I$ am bound to see it. But now I realize I have far exceeded the time allowed me, and I reluctantly turn, to find that I am alone on that awful desert; where are my companions? Many thoughts rush through my brain, the last being that of course I have dipped them below the horizon, and now, without some of my own species to bolster up my conceit, I get, perhaps for the first time in my life, some idea of my relative importance in the scheme of the universe. Now I am a mere tiny black speck crawling over a vast snowy plain, and when again the rest of the party come into view, they too have suddenly sunk into utter insignificance.

It is awe-inspiring, and something of panic seizes me, my pace increases until the five black specks ahead develop head, arms and legs, and, as far as sledging costumes will allow, resemble the supposed highest form of animal life-man. I slacken my pace so that I enter their midst showing no more than a dignified regret at the loss: the journey is resumed. I look at my surroundings now with a new interest, and wonder if any of the others have seen things from the same point of view ; some day I will ask them.

The loss of that jersey soon proves a serious inconvenience. At night, now, I have no extra clothing, and, in spite of the kindness of my tent mates, I get very little sleep : sometimes I am glad to have Wild put his arms round me, and on one occasion I had to pocket my pride and ask him to do it, but they are kindness itself, and every 


\section{FIRST IMPRESSIONS OF SLEDGING}

effort is made to keep me warm. I become middle man permanently, and I nearly suffocated them in turn, chasing them into the corners of the bag to extract a little warmth from them. But I am beginning to feel the want of sleep, and something must be done; an old argument of the professor's occurs to me. I remember hearing him explain to some one, with most conclusive scientific reasons, why the fur mitts were worn with the fur outside rather than inside. Why, thought I, shouldn't this argument be applied to sleeping-bags? and the more I thought it over the more I liked the idea.

I put the case to Joyce and Wild, earnestly expounding my doctrine with what I could remember of the scientific reasoning. They would have none of it, and for three nights we argued steadily, but I was long-winded and persistent; their arguments weakened, until at last I had the pleasure of talking them into silence. Joyce, who was cooking the "Hoosh," at last said: "You know, Frank, I believe there is something in old Putty's idea," and that started it all over again, but now we were two to one, and Frank at last gave in. That night we turned the bag inside out and turned in. Warm and comfortable, we had our first real night's rest since we left the hut. Good old science! In the morning I modestly received the thanks of my grateful tent mates. We were comparatively happy and almost cheerful at breakfast, that most trying meal.

That evening, with feelings of pleasant anticipation, we prepared to turn in. Frank went out for the bag, he was a long time about it, and when 


\section{MEMORIES OF ANTARCTIC DAYS}

at last he did appear, some vague uneasiness came over me, and from the twinkle in his eye I feared the worst. "Here's the bag, boys," and in it came. Nothing out of the ordinary revealed itself at the first glance, but in attempting to unroll it, the united efforts of Joyce and myself were needed to straighten it out, and any effort at getting inside appeared at first to be hopeless. "What the dickens has happened to the bag?" says Joyce, but I was silent and crestfallen. Too well I realized what had happened; here was the answer to the "Scientific reasons" - sleeping on the skin instead of the fur had caused that part of the bag to become damp and it had frozen into a material as hard and unyielding as a board. Never shall I forget the struggle we had to get into it. I apologized, but was readily forgiven, and the previous night's sleep was voted worth it, but never again will I trust to scientific theories unsupported by practical experiment.

We laid that depôt, and turned for home. Delays, owing to blizzards, had made inroads on our food supply, and one hundred miles from home we had just three days' food left. We went on half rations and trusted no more blizzards would delay us. Next day started with low drift, with every evidence of increasing, but we pushed on after all our landmarks were obscured, hour after hour we marched forward into a blanket of white, misty, drifting snow, with occasional pauses to verify the course with the compass.

It was unpleasant work : the sand-like particles of snow sting the face, aggravating the tender scars 98 


\section{FIRST IMPRESSIONS OF SLEDGING}

on frost-bitten noses and cheeks. There is practically no light and shade, so that the inequalities of the surface are invisible, and as we stumbled forward curses are heard at intervals from those unfortunates who have either stepped into an unexpected hollow or stubbed their toes against a hard ridge of snow. At last it becomes too thick to face, and a halt is called, and even as we stop Wild drops into a crevasse, snatches at a sledge, and pulls himself out.

The order is given to camp and, after threequarters of an hour's hard struggle, the six of us manage to set one tent, usually the work of three men for about five minutes. We are frost-bitten and dazed and crowd into the one tent and discuss the situation; we hang on in the hope that it will decrease in fury, but no, it is steady and shows every evidence of lasting. The order is reluctantly given to camp there, and we set up the other tent and prepare our scanty meal. The order to break camp comes in the middle of the night, and we resume our march. We have camped in a small area of solid ground amid a perfect network of crevasses, but they offer no serious problems, and soon we are out of them. The wind drops and landmarks appear. It clears up, and a fine day follows the storm; it is decided to make a forced march while the fine weather holds, and all through that day we steadily press forward. That evening Erebus has risen well above the horizon, and is glowing in the rays of the setting sun, the palest of rose colours at its summit, its base a cold greeny blue; 


\section{MEMORIES OF ANTARCTIC DAYS}

it is a welcome sight, and its apparent nearness is encouraging.

A short pause for a meal and a rest, and forward again. We take it steadily and the miles are ticked off on the sledge metre, the sun sets and with it go all the warm colours from the scene; now everything is grey, but, with heads bent down, we keep up a steady left, right; left, right. We are tired, but pleased with our progress. Suddenly I am aware of an extraordinary change in the appearance of the ground we are covering. It is no longer a cold grey but the purest cerulean blue, splashed with innumerable points of rose madder, the whole so light and fugitive that I hardly realize that it is actually there and not a trick of the eyes. I blink and blink, but that wonderful carpet remains. A glance behind reveals the sun just over the horizon after a disappearance of a few minutes; its level rays have caught all the little inequalities of the surface and for one brief instant changed them into millions of tiny jewels. Now we are near White Island once more, and crossing a crevasse. We reach the middle of the bridge, and it cracks like the report of a pistol. We are too tired to be startled, and, once on firm ground, we sleepily erect our tents, cook our "Hoosh," and turn in for another brief rest ; not for very long, however, for our leader means to reach Hut Point tomorrow. It proves to be a fine day, and as we march forward the warmth of the sun steadily increases, and we have our first really warm day. Windproof coverings are taken off, fur mitts become 100 


\section{FIRST IMPRESSIONS OF SLEDGING}

unnecessary, and perhaps for the first time during that journey our load seemed to have lightened.

Late that evening we reached Hut Point. Long, however, before we reached the hut there we were conscious of the fact that the dogs we had left there nearly one month before were still very much alive, in fact we seriously feared from the noise they made at our approach that their long confinement had driven some of them crazy. We gingerly let down the shutter which confined them, and instead of the four snow-white puppies we expected, four huge coal-black dogs, with staring eyes and gleaming teeth, sprang out on us. For four weeks they had done nothing but eat and sleep, eat and sleep, day after day ; their bed had been a heap of coal dust, and lack of exercise had caused them to get extraordinarily fat, so that we had great difficulty in recognizing them; they, however, knew us, and their joy at our return was pathetic to witness. For days afterwards none of them could approach one of us without going through an elaborate pantomime, meant as an expression of joyous welcome. It was a fatal weakness to say a kind word, for the pantomime would immediately begin over again and the dog reach such a stage of contortion that we feared the result, so we veiled our affection, and they eventually trotted peacefully into winter quarters at our sides. They no doubt went back with a great story to tell of their adventures, but they never told it that day at any rate; their old companions greeted them with snarls of rage; whether they did not recognize them or whether they felt 


\section{MEMORIES OF ANTARCTIC DAYS}

themselves slighted at being left behind, we shall never know, but every dog at the camp turned out to chase the filthy intruders, and it was not until some days after that they were received on anything like their old footing.

And now we enter once more the old hut in whose bright interior we spent such a happy winter. It is unaccountably dim, with dark figures moving about in its recesses. We demand to know what has happened to the gasometer and why the lights are burning so badly. Every one scorns the suggestion of bad light; and it needs the repeated assurance of every one that the light is as usual to convince us that we ourselves once regarded this as a bright and cheerful hut. It is days before we can see easily, but we revel in the warmth and comfort of the hut. My baptism is complete. I have returned from my first sledging trip. 


\section{CHAPTER IX}

\section{THE SHORE PARTY'S MAGAZINE: THE "AURORA AUSTRALIS"}

7 HE Aurora Austratis was printed and produced in the Antarctic, during the long

1 dark night. It is a work which has a very limited circulation, as the issue was of necessity very restricted, and did not, I believe, exceed a hundred copies.

Those who have been privileged to see this rare work would little suspect that it was produced by amateur printers. Everything-typography, imposition (or whatever it is called), lithography, etching, is of the highest degree of technical excellence.

You would not imagine that such work could be put out by three men who only had a few hours of instruction, wedged in among the myriad engagements of the exciting days of preparation for an expedition!

Joyce and Wild are responsible for the typography; Marston devised, drew, etched, lithographed, and printed all the illustrations in the book, including the coloured title-page.

Sir Joseph Causton very generously provided all 


\section{MEMORIES OF ANTARCTIC DAYS}

the materials - type, paper, printing presses-and had our printers instructed at his Works.

Day, without any instruction at all, set his deft fingers to work and made the covers out of our empty venesta packing cases. Many of the covers still bear conspicuously the stencilled brand telling the nature of the contents, such as $\mathrm{S} \mathrm{U} \mathrm{E} \mathrm{T,} \mathrm{B} \mathrm{A} \mathrm{CON,}$ etc.

The reader, contemplating the finished work, would have no glimmering of suspicion of the immense difficulties under which the work had to be produced.

It was winter, and dark, and cold. The work had to be done, in the intervals of more serious occupations, in a small room occupied by fifteen men, all of them following their own avocations, with whatever of noise, vibration and dirt might be incidental to them.

The inevitable state of such a hut, after doing all possible for cleanliness, can be imagined. Fifteen men shut up together, say during a blizzard which lasts a week. Nobody goes out unless on business ; everybody who goes out brings in snow on his feet and clothes. Seal-blubber is burned, mixed with coal, for economy. The blubber melts and runs out on the floor; the ordinary unsweepable soil of the place is a rich compost of all filth, cemented with blubber, more nearly resembling the soil of a whalingstation than anything else I know.

Dust from the stove fills the air and settles on the paper as it is being printed. If anything falls on the floor it is done for; if somebody jogs the com104 


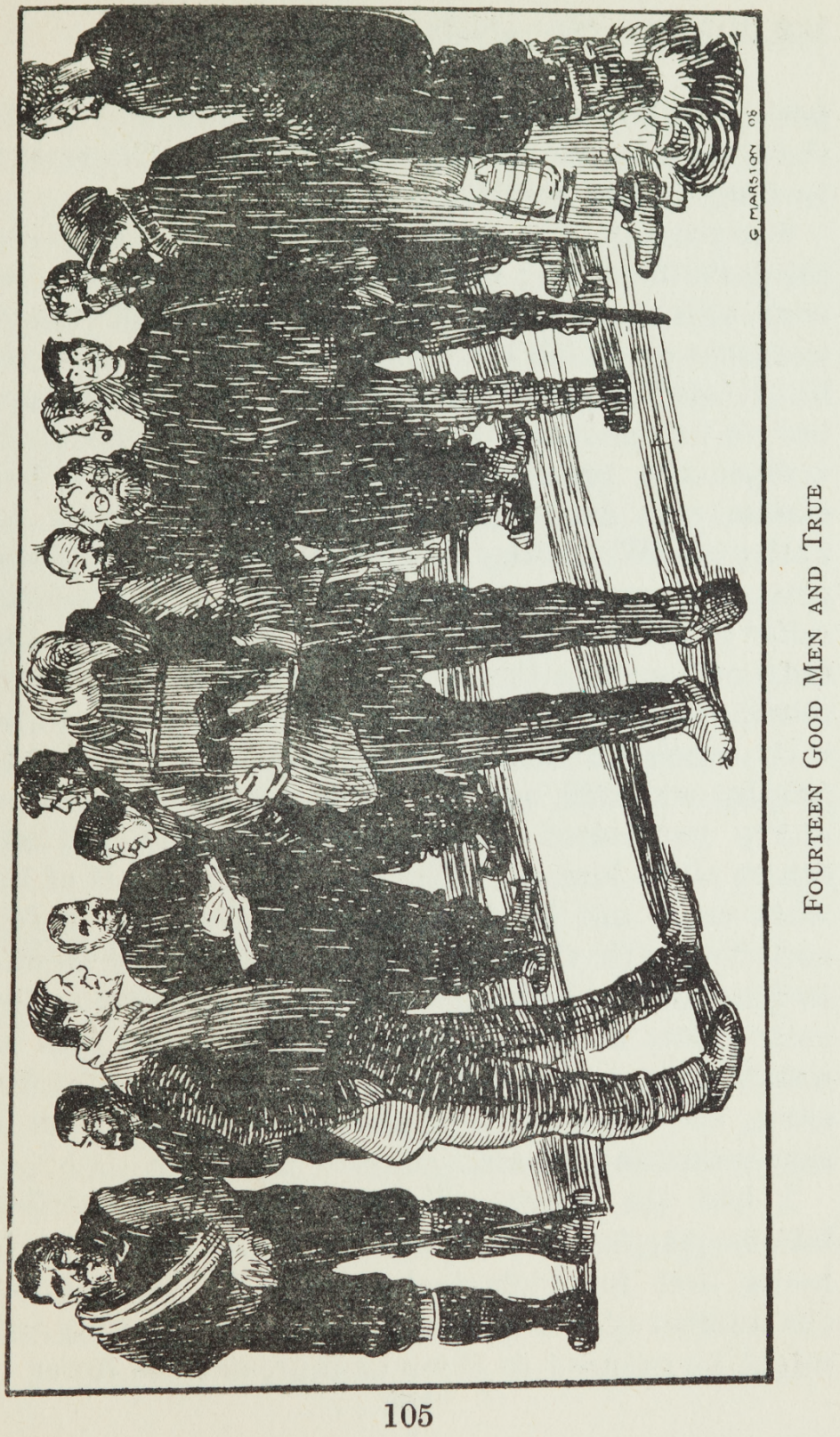




\section{MEMORIES OF ANTARCTIC DAYS}

positor's elbow as he is setting up matter, and upsets the type into the mire, I can only leave the reader to imagine the result.

The temperature varies; it is too cold to keep the printer's ink fluid; it gets sticky, and freezes. To cope with this a candle was set burning underneath the plate on which the ink was. This was all right, but it made the ink too fluid, and the temperature had to be regulated by moving the candle about.

Once the printers were called away while the candle was burning, and nobody happened to notice it. When they returned they found that the plate had overheated and had melted the inking roller of gelatinous substance. I believe it was the only one on the Continent and had to be re-cast somehow.

So much for the ordinary printing. The lithography was still worse. All the evils enumerated above persecuted the lithographer, and he had others all to himself. The more delicate part of his work could not be done when the hut was in full activity, with vibration, noise and settling smuts, so Marston used to do most of his printing in the early hours of the morning, when the hut was as nearly quiet and free from vibration as it ever became, and there was a minimum of dust (at least in suspension in the air).

I had the opportunity of observing his tribulations, as, for similar reasons, I found the early hours best for biological study. At these hours the number of loafers round the stove (drinking tea) might be reduced to three or four, or even fewer. 


\section{THE SHORE PARTY'S MAGAZINE}

I do not pretend to know the nature of the special difficulties that the climate introduced into lithography, but I know this, that I've frequently seen Marston do everything right-clean, ink, and pressbut for some obscure reason the prints did not come right. And I've seen him during a whole night pull off half a dozen wrong ones for one good print, and he did not use so much language over it as might have been expected.

Thus was this Magazine produced. The matter contributed to the Aurora (I had almost forgotten to mention it, so it is obviously a matter of secondary importance) was, I think I may venture to say, on the whole worthy of the printing.

In order to give a wider circulation to some of this work produced in the Antarctic, I have here reproduced several of the best articles and illustrations, at the request of the Editor of the Aurora Australis, Sir Ernest Shackleton.

\section{EREBUS}

Keeper of the Southern Gateway, grim, rugged, gloomy and grand;

Warden of these wastes uncharted, as the years sweep on, you stand.

At your head the swinging smoke-cloud; at your feet the grinding floes;

Racked and seared by the inner fires, gripped close by the outer snows.

Proud, unconquered and unyielding, whilst the untold æons passed, 


\section{MEMORIES OF ANTARCTIC DAYS}

Inviolate through the ages, your ramparts spurning the blast,

Till men impelled by a strong desire, broke through your icy bars ;

Fierce was the fight to gain that height where your stern peak dares the stars.

You called your vassals to aid you, and the leaping blizzard rose,

Driving in furious eddies, blinding, stifling, cruel snows.

The grasp of the numbing frost clutched hard at their hands and faces,

And the weird gloom made darker still dim seen perilous places.

They, weary, wayworn, and sleepless, through the long, withering night,

Grimly clung to your iron sides till with laggard Dawn came the light:

Both heart and brain upheld them, till the longdrawn strain was o'er,

Victors then on your crown they stood and gazed at the Western Shore;

The distant glory of that land in broad splendour lay unrolled,

With icefield, cape, and mountain height, flame rose in a sea of gold.

Oh! Herald of returning Suns to the waiting lands below ;

Beacon to their home-seeking feet, far across the Southern snow.

In the Northland in the years to be, pale Winter's first white sign 


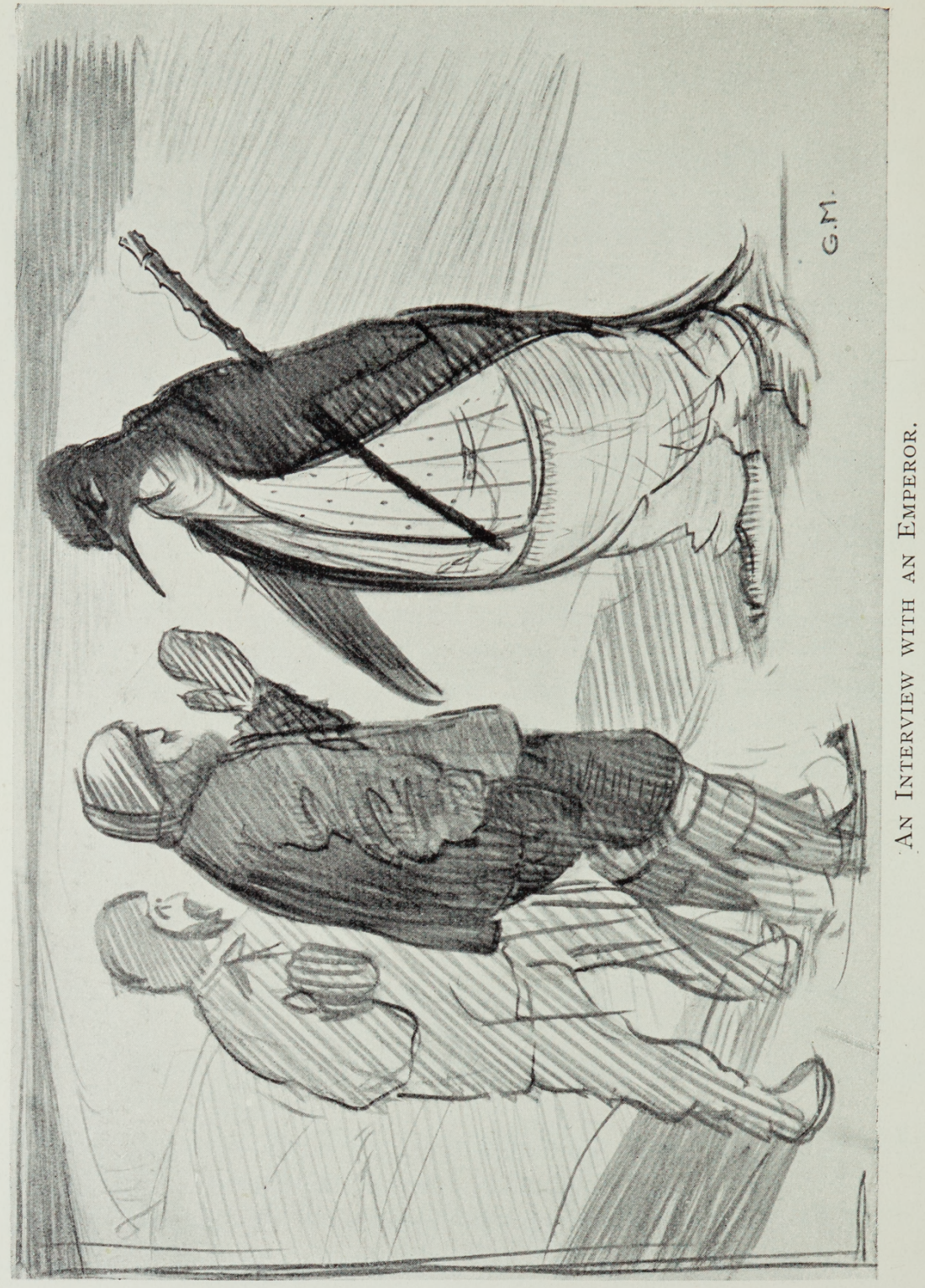




\section{THE SHORE PARTY'S MAGAZINE}

Will turn again their thoughts to thee, and the glamour that is thine.

Nemo (E. H. S.).

\section{AN INTERVIEW WITH AN EMPEROR}

It was a perfect Antarctic winter night. A $\mathrm{A}-$ and I were trudging merrily along over the sea-ice, under the cliffs to the north of Erebus, for in such weather it seemed a crime to remain indoors.

The moon shone full, dimming the stars and paling the sky in the zenith, though round the horizon its colour deepened into a rich ultramarine. On our right towered the mighty volcano, swelling up at first in long glittering snow slopes, which formed a noble pedestal to the beetling rocky spurs which buttressed the summit cone and ice-cap.

From the active crater jetted a delicate pure white stream of curling vapour, clear-cut against the sky, like a cameo tracery. It was a scene in whites and blues, only relieved by the rich brown of the rocks.

But such whites and blues! They were livid, ethereal, electric. Artists speak, I believe, of a dead white, but such an adjective could never be applied to the whites of the Antarctic snows by moonlight.

It would be a platitude to compare the whole to a vista of fairyland, and perhaps an anti-climax to say that it was like some lovely transformation scene, viewed by the wrapt gaze of childhood.

One thing is certain, that the whole effect seemed almost supernatural, and it did not require an im109 


\section{MEMORIES OF ANTARCTIC DAYS}

pressionable mind to be uplifted by it to a height almost more than mortal.

So we swung along; it seemed as if fatigue were one of those earthly ills left far behind us in prosaic temperate climes.

The creaking snow, blown down and packed hard by the southerly blizzard from the slopes above us, made the most perfect going. The ever-changing views of the broken ice-cliffs and mountain slopes drew us on. We felt as if we could have gone on for a week.

Yet it was strange, and almost uncanny to think that in all the miles and miles of land over which our eyes ranged there was not one living, breathing creature-no, not one !

The Adélie Penguins, those cheery summer visitors, had gone far north with the sun, ten degrees below the horizon. The seals were away out on the edge of the sea ice, and that was farther away, at any rate, than we could see.

True, the Emperors, most majestic of living birds, are said to conduct their royal accouchements in this region in July, that is, the depth of our winter, and it was June as yet.

But we were going in the direction of the Emperors' rookery at Cape Crozier, and in this wonderland anything might happen.

Trudge, trudge, trudge we went, saying very little. It was no time for conversation. Those who don't know what a polar climate is like, might think we felt cold, but no such discomfort dashed our elated spirits. 


\section{THE SHORE PARTY'S MAGAZINE}

This goodly portion of the Earth's fair surface was ours. No polluting foot save ours defaced its virgin solitudes. We might fare where we list; none could say us nay.

No "Trespassers Will Be prosecuted," here. No "Private grounds, no thoroughfare."

No uniformed park-ranger, or corduroyed gamekeeper could bar our way, with horrid threats, and perhaps still more horrid action.

But stay!-What form is that emerging from the shade of yonder iceberg? It strides towards us with swinging gait, recalling to my mind unpleasant memories of my bird-nesting days.

I cannot control a strange flutter of apprehension in the slack of my trousers, a sort of prophetic sensation of tenderness behind.

That is strangely like a knotted cudgel carried, with ill-concealed menace, under the left arm. "No Gamekeepers," did I say ? It must be a gamekeeper.

But he is upon us. All doubt is banished. He is the most enormous Emperor Penguin I have ever met. Full six feet high, and broad quite out of proportion, his appearance is so extraordinary that I must describe it minutely.

The large, angry eyes, glaring from beneath a close-fitting cap, drawn down over the ears, flank a prodigious black bill, a foot Jong and curved like a scythe-blade. He wears a black velveteen coat with long skirts, and underneath this a white moleskin waistcoat with brass buttons, and baggy trousers of the same colour. The delicate creamy tinge which I have observed on the throats of common Emperors 


\section{MEMORIES OF ANTARCTIC DAYS}

is developed into a gorgeous red and gold collar or stock. Under his arm, or flipper, he carries a heavy truncheon, fashioned from the backbone of a seal. As he stood before us, all this could be taken in at a glance.

I have had many a painful interview with gamekeepers, and people of that kidney, but this one would take all my diplomacy to meet. But a bland smile and a voluble tongue might pull us through.

"If you please, gamekeeper, park-officer, I mean," I began :-

But he interrupted me in a harsh voice, and with an accent strongly reminiscent of the land of cakes :

"Noo then, you twa," he cried, "what the deevil are ye daein' here? Ye ken vara weel this is private property. Let me see what ye hae got in your pockets."

When I had first seen him I had instinctively plunged my hands into these receptacles, with the idea of dropping anything of a compromising nature into the nearest ditch. But my fingers came in contact with something of a different nature.

I seldom go for a long walk without that vademecum, universal panacea, and open sesame, a pocket-flask.

I grasped it, and my courage revived. If "wi" usquebaugh" I could face the deevil, why not an Emperor Penguin? I was in case to justle a constable.

Our enemy, however, was in an aggressive mood. We hesitated at the idea of turning out our pockets to this truculent fowl, so he, without more ado, passed 
his stick over my clothes. It struck my flask with a full sound. At once his worst suspicions were redoubled.

"Come away, noo, oot wi' it," he cried. "Yon's an egg, ye young rascal, if I'm no' vera much mistaken."

"Indeed it is not," I replied, with new-found confidence. "That's my pocket flask, by the way, have a dram, will you?" For I thought this was the psychical moment for the introduction of this delicate, but at the same time not disagreeable subject.

"Na, na, laddie," he said, " no" sae fast as a" that. I'll jeest take your names and addresses and what's your business here."

Now there are many ways of revealing one's identity and asserting one's position on an occasion like this, but there is none so dignified, not to say majestic, as the display of a clean visiting-card. A lightning thought struck me, and plunging my hand into my breast pocket, I produced the required piece of pasteboard, with an austere flourish and a general air of hauteur. True, it was curled up at the corners, and rather soiled with tobacco ash, and, in place of my own august cognomen, it bore that of an enterprising washerwoman, who had sent it on board at our last port of call.

But it fixed our friend the enemy. He scratched his head, looked at it upside down, then backside foremost, and finally pulled off his cap, stuck the card in the lining and replaced the cap on his head.

"Weel, Gentlemen," he said, "I'll jeest show ye 113 


\section{MEMORIES OF ANTARCTIC DAYS}

aff the estate if ye'll tell me whaur ye come frae, and what's yer beesiness?"

"Well! come now, my man," I replied, " have a dram, and I'm sure we're very sorry to have caused you any trouble."

With that I again brought forth the flask. He took a long gurgling swig, coughed and threw back his head, shutting his eyes and smacking his bill in a way half human, half galline.

"Man, yon's the richt stuff," he murmured, handing it back. "It's gey scarce aboot here."

"And pray," I went on, thinking it well to avoid an answer to his last question, "whose estate do we happen to have trespassed upon? I was not aware that there were any private grounds in this district."

"Oo, jeest Mr. Forsteri, Aptenodytes Forsteri, a cousin o' the M.P., I'm surprised ye didna ken, man ! It's a vera auld family."

"No doubt," I replied, "but you see we are strangers here. But does all the ground about here belong to Mr. Forsteri ?"

"Oo aye, sir, ye'll see the march burn ahint ye there, by the laich side o' yon big scaur? The Maister's vera parteeklar about this time o' year. Ye see a' the gentry will be comin' for the nestin' in June, and if he was tae see ye here then I dinna ken what he would say."

"But we're very inoffensive people, you know. We're geologists, we just go about collecting stones for our own amusement."

"Wha-at, gatherin' stanes, are ye? Ye're surely 114 


\section{THE SHORE PARTY'S MAGAZINE}

no' nestin' tae? Ye canna possibly dae it about here. The Maister wouldna hear o' it!"

I should explain that the penguin builds his nest of stones only, so I hastened to explain.

"Oh! no, no," I said, "we merely collect the stones to take home, and show to people who are interested in them."

"Besides," said A — in a tone of deep melancholy, "we've no hens with us."

"Aye, aye," he replied, nodding his head thoughtfully, " ye'll be frae yin o' they expedeetions, are ye no'?"

"Yes," I said boldly, seeing that the cat must come out of the bag. "We are from the British Antarctic Expedition of 1907."

" Mphm! are ye though? Ye're queer folk, man! I often wonder what brings ye here. I mind the last yin that was here, somewhere about seven years syne.

" A pack o' them cam' ower tae the rookery, after the maist o' us was gane. We thought they were sea-leopards at first, and some o' the weans was gey scared.

"But as far as I ken, they ta'en naething but a wheen auld rotten eggs. What in a' the world they were gaun tae dae wi' them is a pairfect meestery tae me.

"The Maister was no at hame at the time, but he was awfu' vexed when he heard tell o' it. He said he would ha'e the law o' them if they ever came again."

"Well! I hope we will get on better with you," 115 


\section{MEMORIES OF ANTARCTIC DAYS}

I said. "We'll try not to annoy you in any way."

I wondered at the time if he would object to being stewed, for we were all growing rather tired of Adélies.

All this time we had been walking slowly back towards the hut. I kept hoping that our new acquaintance would leave us, for I dreaded what might happen if we met any of our dogs.

The sight of this majestic bird, pursued by half a dozen yelping curs, tobogganning along on his stomach, and tearing all his brass buttons off on the ice, would have been most painful to me.

But my mind was soon relieved. Our friend stopped and looked round him, squawked thoughtfully, and, extending a flipper to me, he said :-

"Weel! here we are at the march. I'll jeest say good-bye tae ye.

"I would advise ye no' tae come ower here again till the Maister's gane.

"It's no' that I care much mysel', but he's vera parteeklar."

We shook hands with him, and started away for home.

"Quite a civil bird," I said to A-.

"Yes," he replied, " and I thought, rather intelligent." But his voice "far, far away did seem."

I pinched myself surreptitiously, glanced at my companion and then over my shoulder. Not a sign of our late acquaintance was to be seen, and there was hardly an ice-hummock about that could have concealed him. 


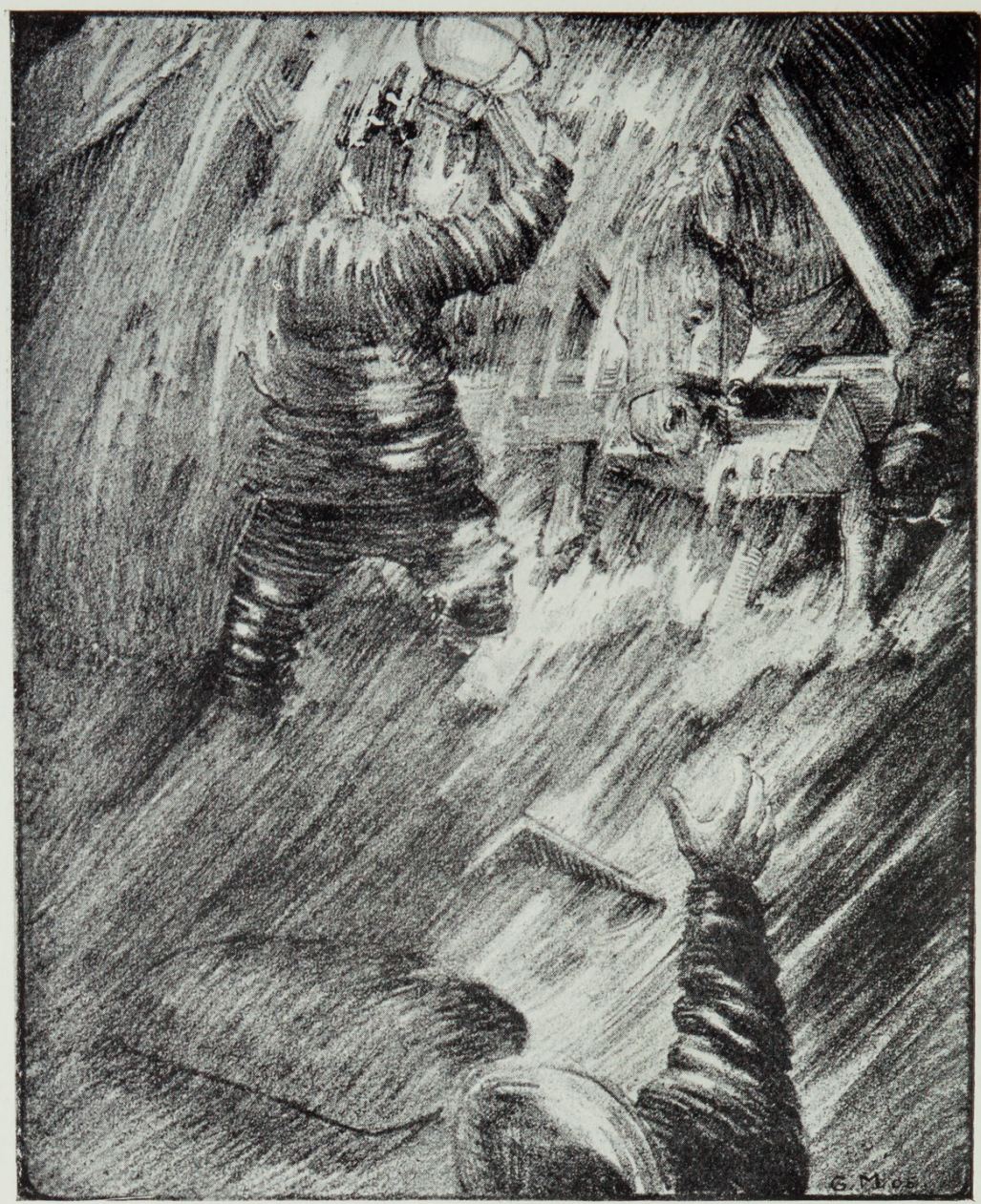

A Pony Watch. 


\section{THE SHORE PARTY'S MAGAZINE}

Was it all a dream, then?

At any rate, we have obeyed his orders.

\section{A PONY WATCH}

After watching the man painting the lamp-post with a brush fixed on a breast drill, for some time in silence, I say to the boy with green hair, "I believe I could do it better myself." The brush catches me a blow in the ribs, and the man rushes at me with a chopper in one hand and a hammer in the other, when, realizing that I can fly, I take huge leaps without any effort, a most delightful sensation.

To my horror, I find that though the leaps are high yet they do not carry me far; and on the fourth or fifth the man is waiting for me with the hammer. I give myself up for lost, and come down receiving a fearful blow on the head. A voice says, "Come on, this is your pony watch and it has gone two."

By the dim light of the oil lamp, I see standing by the side of my bunk, a figure clothed in oilskins streaming water. Joyce is sitting on his bunk growling out in a voice hoarse with sleep, "Now then, Chucks, you've been called twice." The first time must have been the paint-brush in the ribs.

I realize that I have to stand my two hours watch in the stables, so struggling out of my blankets, I grope sleepily for the socks I have been sleeping on, in the vain hope of drying them ; stepping on the spot where a box should be, I land with a bump on the deck.

Down "Oyster Alley" I am thrown by a roll of the ship. "Sorry," I say to the bunk into which I 


\section{MEMORIES OF ANTARCTIC DAYS}

am thrown, before I notice it is empty. Clutching everywhere, I return to where my clothes should be, only to find that the box has returned, and I stub my toe against it. I don't say "sorry," but make a grab at my trousers and gingerly push one leg into their damp, cold recesses. I wish I had not taken them off, but before I can settle in my mind which would have been the better plan, I am thrown violently against a moving box, and together we roll and slide until the deck is fairly level; then as Joyce runs up the ladder with practised steps, I struggle into the rest of my clothes and follow as best I can.

The watch we are relieving come along muttering, " Rough night, pony still down," and literally dive below. I am deafened by the roaring wind, blinded by the driving spray, but struggle past the black, motionless figure of the helmsman, and get safely under the shelter of the deck house. We seem to be sliding into a gigantic bowl of water; I shudder, but continue to fight my way stableward.

Watching for what I think to be a favourable moment, I release my frantic hold of the motor car stays and dash forward; I am caught by a sea which fills my boots but does not upset me, then as I walk confidently past the galley, the lee rail is buried under water; I am more than ever convinced that it is a rough night, and long for daylight.

A wild struggle through the stable entrance, and I am greeted by a pained silence from Joyce. The ship is fairly level, but the ponies have obviously had a bad time; one is down, and all efforts to raise 118 


\section{THE SHORE PARTY'S MAGAZINE}

it having been useless, we wait for daylight to decide its fate. We stare ahead, listening to the gale screaming overhead, and feel the ship giving sudden plunges as the cable strains at her bows.

The timbers of the stable groan and creak, and we doubt their ability to carry the weight of boats and gear resting on them. Gaining confidence we seat ourselves on a sack of wet bran and fall to talking fitfully; the lamp splutters, goes out, and is lit with difficulty; the ponies snort, stamp, kick, and keep us anxious.

Crash! a sea aboard and the sack on which we are sitting is swept from under us, we are rolled into the smother of sea, mixed up with trusses of hay, sacks of oats, food-boxes, etc. The ponies on the weather side kick frantically, one has his forelegs over the bar; Joyce is up and pushing him back before I can extricate myself from the tangle; when I do, I only hold on to a rope and render what assistance I can.

This is followed by a succession of seas aboard, and we heap curses on the helmsman for letting us fall off our course. Occasionally we are swept off our feet, and can only hold on and do little to soothe the ponies. They suffer continually, and we pity them, hoping for finer weather. The mats are slipping from under their feet, we replace them with difficulty and repeat the performance at intervals. Another period of comparative calm follows; I volunteer to raid the galley and make some cocoa. Here there is a scene of wild confusion; the floor is flooded, littered with coal, and slippery with grease; 


\section{MEMORIES OF ANTARCTIC DAYS}

after many mishaps, "Scottie" coming along gives valuable assistance.

Crash ! a huge sea strikes us, and the ship literally staggers with the weight of it; water pours through the door, roof, and every available crevice; the fire is smothered and the galley fills with steam; another rush of water and I am carried through the door into the scuppers, clinging to everything within reach, then as the water pours off, "Scottie," soaked but quite unconcerned, says he is afraid that there is some sea water in the cocoa, but I abandon the idea of cocoa and rush for the stables.

Joyce is having a rough time, the bulwarks are stove in and we are now constantly awash. The rest of the watch consists of fierce inrushes of water, which terrify the ponies and send every loose article, regardless of weight, swinging about the confined space. The grey dawn at length appearing, we begin to have faith in the coming day.

At four o'clock I go aft, report to the officer on watch, then dive into the fearsome depths of "Oyster Alley" ; rouse the watch, and when they are up, tumble into my blankets with a sigh of relief; despite a wild medley of scientific snores, sleeping on until "Rouse and shine, rouse and shine," from Wild brings me out to a welcome breakfast, and I learn with regret that the pony has been shot; and so another day begins.

PutTy.

\section{TRIALS OF A MESSMAN}

"Rise and shine! Rise and shine! All hands lash up and stow hammocks! Show a leg there, 120 



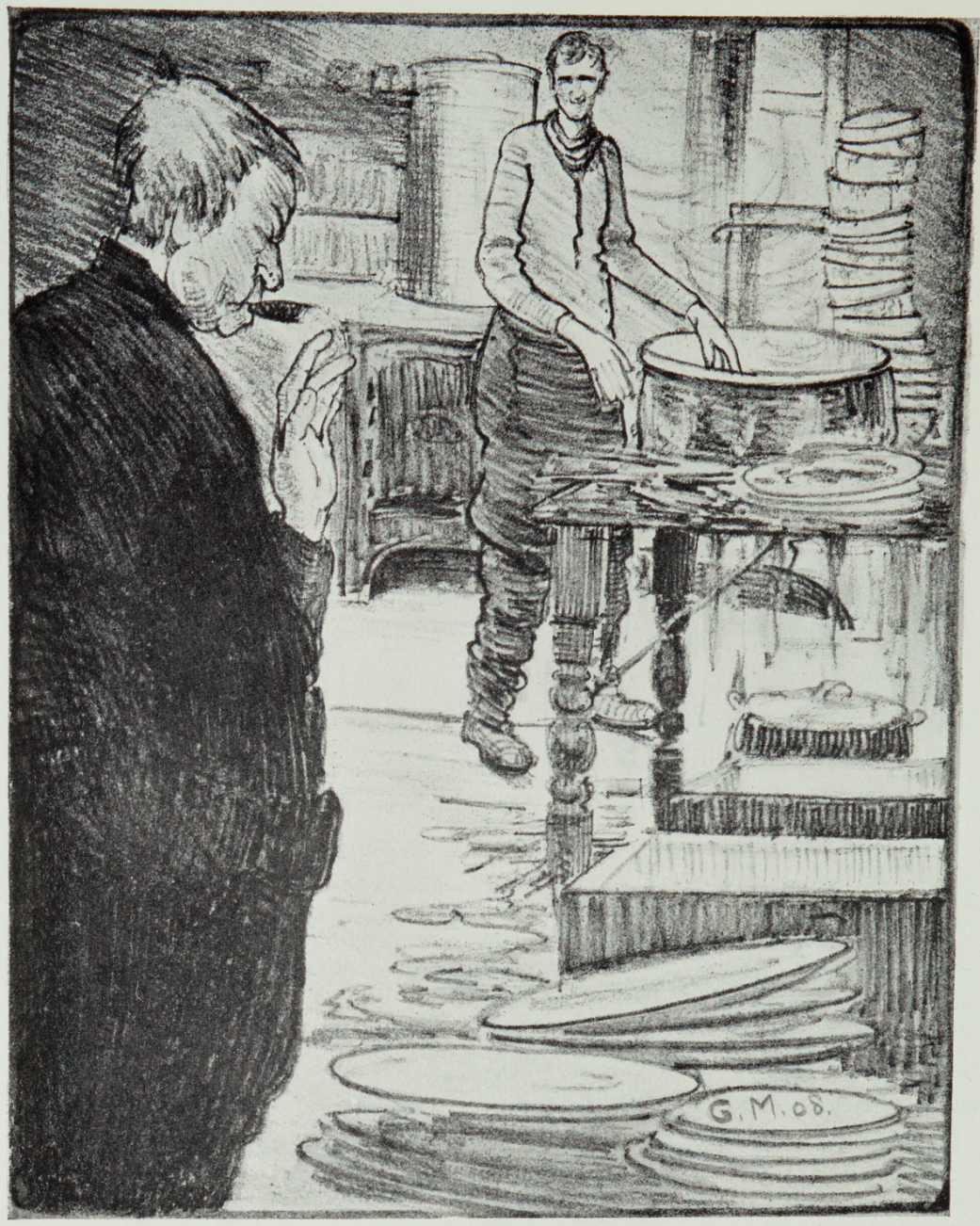

The Messman. 


\section{THE SHORE PARTY'S MAGAZINE}

you're the man of the moment!" followed by a few remarks on my personal appearance and habits, as $I$ try to lie and seem to be asleep, and I awake to the realization that I am "Messman."

Until a iew weeks ago I didn't even know what the name meant, except that he was not a man who was expected to make messes, and that unpleasant personal remarks were made to him if he did. Now, however, I have learnt by experience that he is expected to do everything and to do it all at the same time. Finding it impossible to impress on the night-watchman the fact that, having a delicate constitution, I ought not to be expected to turn out with the temperature at $20^{\circ} \mathrm{Fahr}$., I gave him my candid opinion of his powers of stoking, and said I was pretty sure that, in a future sphere, he was likely to give dissatisfaction.

Having turned out and donned a fair supply of clothes, I reported myself to my chief, and was told in very concise terms to go to a warmer clime ; it afterwards turned out that he expected me to do my duty as messman first, and I laid the table for breakfast.

A meal in the Antarctic is a very different affair from one at home, and a description will come better from the messman than from any one else, for, as the saying is, "The onlooker sees most of the game," and as far as my experience goes, the messman at a meal is very much in the position of a spectator.

At a quarter to nine he gives the order, "Boats crew," and four men proceed to unsling and let 


\section{MEMORIES OF ANTARCTIC DAYS}

down the table, which between meals is kept slung above our heads, occupying much the same position in our imaginations as the sword did in that of Damocles. I have not liked to walk underneath it since the supports gave way and landed the majority of the tin-ware on the heads of one or two members of the party.

The table in itself is a curiosity ; it is built rather ingeniously of the lids of cases, and in one place a legend informs the diner that the table contains a theodolite, some ranging poles and other surveying apparatus, while another legend remarks that it is only "To be opened on Christmas Day," etc.

Laying the table is an art in itself. The tastes of all members have to be catered for, and that means that it is necessary to have two or three different kinds of jam, marmalade, honey and golden syrup, dripping and butter. I have seen men spreading chutney on their bread and putting honey in their porridge, and, from the way it has disappeared, I have reason to believe that they take Worcestershire sauce with their fruit.

At nine o'clock I serve the porridge, distributing it about equally between the inside and outside of the bowls, and at five or ten minutes past the company condescend to turn out of bed, and the first thing they do is to find fault with the laying of the table.

On one never-to-be-forgotten occasion I forgot the pepper. Now the menu for the morning was porridge, fruit and preserves; what use any one could find for pepper in that breakfast, I do not 


\section{THE SHORE PARTY'S MAGAZINE}

know, but within ten seconds of their arrival at the table, every other man had asked for it and told his neighbour what he thought of me for not putting it on the table. If it happens to be a fruit day, i.e. a day when for second course fruit takes the place of meat, the next order given is, "Bowls up and lick spoons," there being only about fifteen of each article on the Continent, and the bowls and spoons which have been used for porridge are cleaned in this alfresco way and used for fruit.

For about a quarter of an hour everybody is too busily engaged to be captious, but about the time tea or coffee are being passed round they begin to find their tongues, and I sit down to my breakfast, which is stone-cold, beneath a fire of criticisms as, to to my fitness, or rather my lack of fitness, for the post.

After breakfast I wash the crockery and tinnery, being allowed a pint of water and a couple of lumps of soda to do it with. Volunteers have been known to assist in getting the grease off the plates and in drying them, and it is possible to get through the work in about an hour.

It is a sight for the gods to see a well-known F.R.S. drying a wet plate with a wetter cloth, and looking ruefully at the islands of grease remaining, after he has spent five minutes' hard work on it. I suppose that nowhere else in the world is it a common sight to see two geologists and a meteorologist washing up dishes as if they had been used to nothing else.

The above programme is repeated three times in the day, with slight variations at lunch, tea and 


\section{MEMORIES OF ANTARCTIC DAYS}

dinner, and is in itself, in my opinion, sufficient work to last three men and a boy for a week.

The messman also enjoys quite a number of other privileges. He is allowed to go out into the cold and obtain enough ice to fill both the boiler from which we ourselves drink and the eighteen gallon melting pot which provides the fresh water for the Cavalry Commissariat Department, and he may do this as often as he likes. He is allowed to fetch bags of coal and strips of frozen blubber for the fire, while on Sundays, as a great treat, he may dig out the frozen mutton from the snowdrift on the roof.

With everything apparently united to afford him plenty of employment and make him happy, yet, strange to say, he has his moments of despondency. No other occupation could cause a man to have such a low opinion of his own powers.

To a casual observer stoning raisins appears to be easy enough, and until my first day as messman I had been a very casual observer, and when the autocrat at the head of the Food Department gave me some raisins after lunch, and told me to stone them, I looked forward to a restful interlude in what had so far been a strenuous day. I washed my hands until they were of a colour which I thought could not show on the raisins, even if it did come off, took a tin of raisins and a basin, settled myself in a comfortable position, and started.

At the end of half an hour there were seven whole raisins and forty-nine pieces in the basin, stones scattered all over the hut and myself, raisin in my 


\section{THE SHORE PARTY'S MAGAZINE}

hair and in everything else within reach, and about two hundred raisins inside various members of the Expedition. There was raisin in everything at dinner, from the soup to the tea, and I meet raisin stones in my bed, on all my clothes, and in all my books.

Last, but not least, I retired from the fray with my respect for all people who make cakes and puddings greatly enhanced. In the words of a prominent scientist on the Expedition, "To a man of my refined and sensitive nature, it is singularly repulsive to be beaten by a fruit."

Another duty new to me is making tea, and it is by no means a light one. The capacity of this Expedition for tea is simply marvellous; some of the members take it in a bath, and among the many things I have learnt is that some Scotchmen take more tea than "whuskie" (though that may be because they can get no "whuskie"), and that they are more particular about it than even Australians. It is either too hot or too cold, boiled too much or not boiled at all, too sweet or not sweet enough, and whether it is good, bad or indifferent, there is never enough of it. Like most other messmen, I have decided now to make it to suit myself, and have ceased to pay any attention to criticism.

I should not like to finish without expressing my gratitude for one thing. To a lover of human nature it is very gratifying to see artists, geologists, biologists, meteorologists and other "ologists" and " ists," fighting in vast numbers and with earnest purpose, for the privilege of sweeping out the hut 


\section{MEMORIES OF ANTARCTIC DAYS}

after dinner, and relieving the messman of this exercise. I have not liked to thank them to their faces, but thought they might blush unseen when they saw in print my appreciation of their eagerness. 


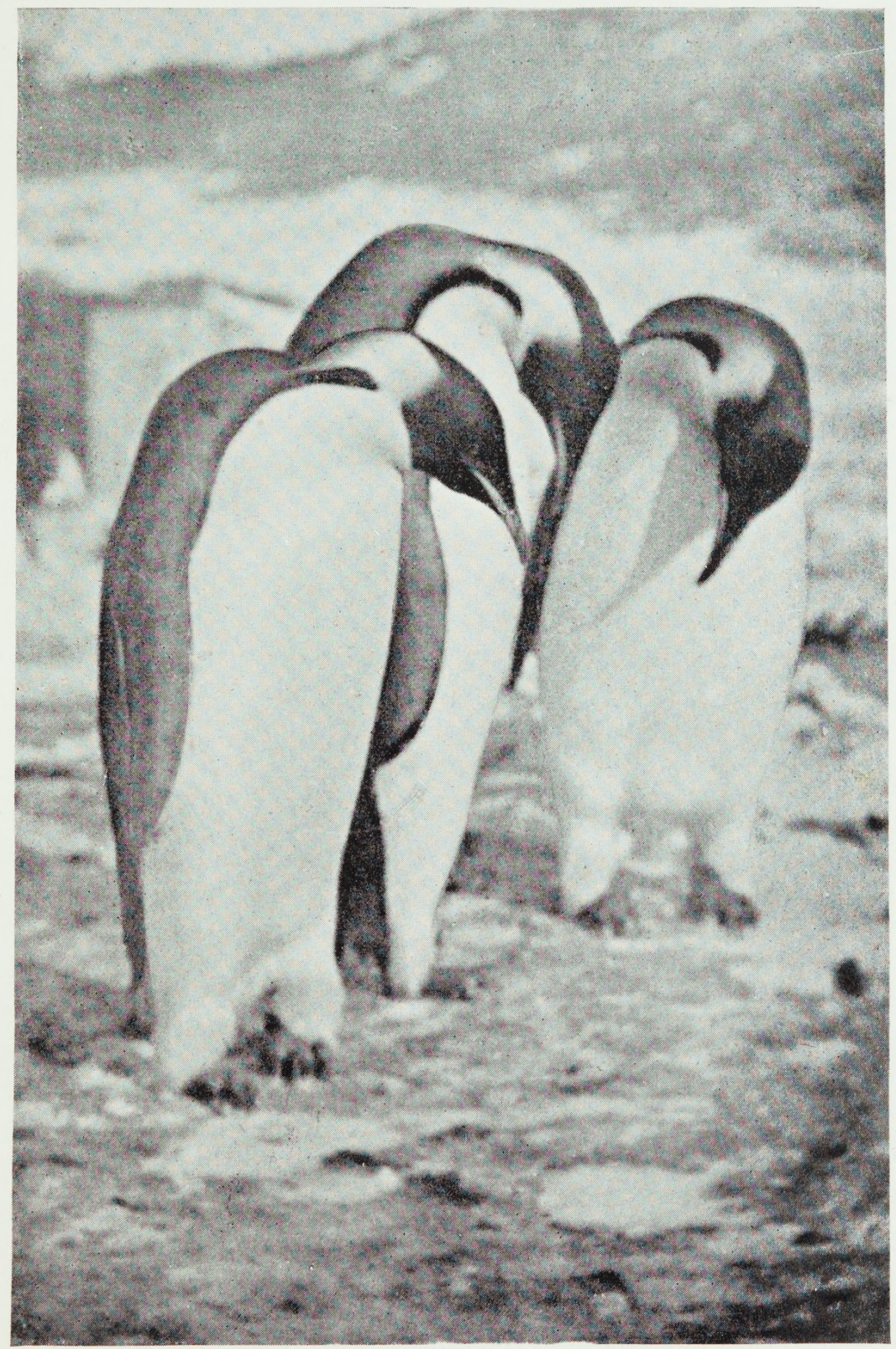

“ Good Morning!" 

ANIMAL LIFE: PENGUINS, SEALS, ETC.

\section{CHAPTER $X$}

\section{ANIMAL LIFE : PENGUINS, SEALS, ETC.}

THE Antarctic would be a dull place indeed were it not for the Penguins, and even the Seals, stolid though they be, add interest to a residence in the region.

The extreme abundance of animal life, of a very few sorts, in the Antaretic, has attracted the attention of every visitor to this region-Adélie rookeries which must number millions of inhabitants are scattered all along the coast-Emperors, coming from nobody knows where (for there can't many of them come from the only known rookery at Cape Crozier), arrive daily in bands of hundreds, inspect your camp, and pass on, nobody knows whitherhuge Weddell Seals, each weighing anything from five hundredweights to half a ton, lie about in groups on the fast ice, to as many as a hundred together, though herds of such numbers are rare.

I have often wondered how a colony of Esquimaux from Smith Sound would find themselves if they could be transplanted to Macmurdo Sound. They would think they had got to Heaven, I imagine! Nothing to do but kill your whole year's supply of food in an hour, and then spend the year eating 


\section{MEMORIES OF ANTARCTIC DAYS}

it. And even if the Esquimaux had been improvident, as he doubtless would, odd seals would come up often enough during the winter to prevent any anxiety about the food supply.

Just think of a poor Esquimaux who has had to go out in the coldest part of the winter, and wait perhaps for two days at a blow-hole on the chance of securing a little hundred-and-fifty-pound-seal, which, when caught, has to serve the whole tribe for a month-just think of him planted down in the midst of a five-million rookery of Penguins which will not go away, or beside a densely-packed herd of juicy half-ton Weddell Seals !

But I fear that if the Esquimaux could attain to this earthly paradise he would have to leave his favourite dogs behind. To a permanent resident the dog would only be a menace : not being needed in any way to find food for you, he plays havoc with the food supply, driving away seals and destroying hundreds of Penguins. The dog would not be needed for travelling, for there would be no need to travel.

I suppose there is a much greater variety of animal life in the North, and no doubt some of the kinds live in colonies, but I don't think there can be anything there to correspond to these vast cities of Adélies, so human in their deportment.

Most of what I have noted of popular interest about Penguins and Seals has already been written in The Heart of the Antaretic, and I do not propose to dish up this material anew, even written up in quite different form. I only intend to touch on 128 


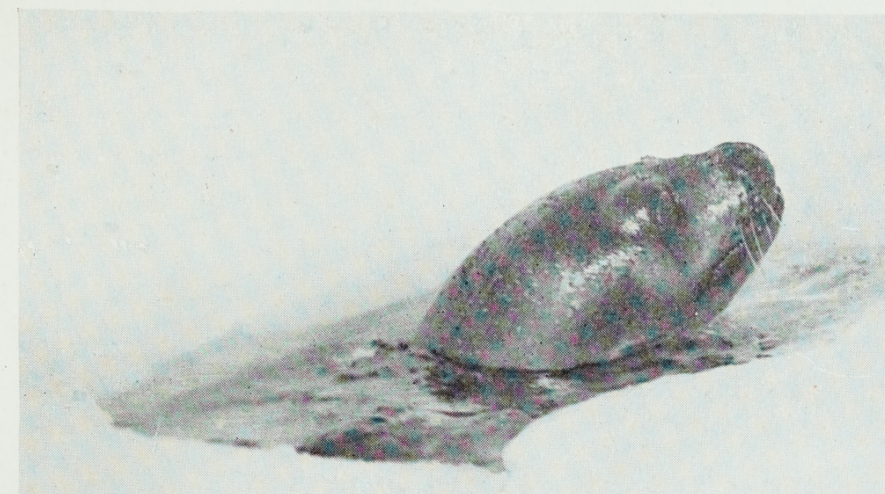

Hulloa !

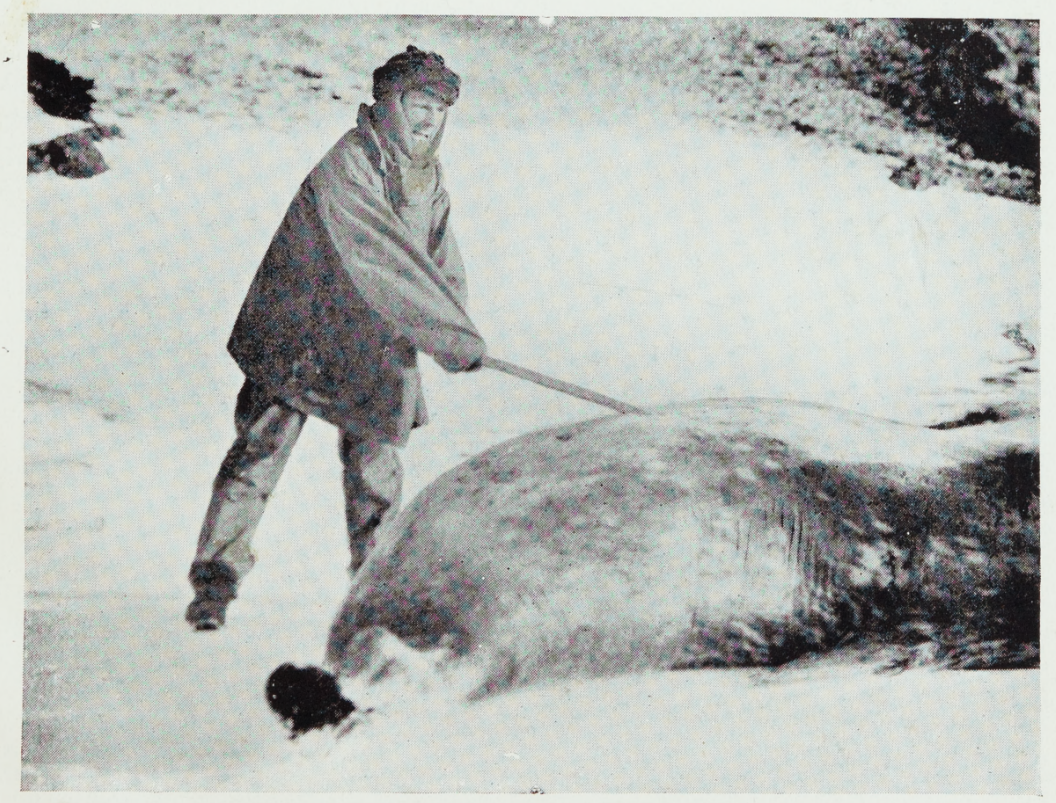

Not so Bad as it seems.

Not a case of diabolical cruelty to animals, but an amiable young fellow trying to make a Weddell Seal sit for her photo. 

ANIMAL LIFE: PENGUINS, SEALS, ETC.

some phases of Antarctic life not already written about (by me), and to present a series of hitherto unpublished photographs illustrating such phases.

\section{THE PENGUINS}

All the books of Antarctic travel must of necessity give conspicuous attention to an animal so prominent in the economy of the region as the Penguin, and they contain legions of excellent photographs, including pictures of nesting groups, as well as general views of rookeries.

If any apology is needed for offering another small series of studies to the number, let it be given in the statement that during the whole breeding season, when most of the other photographers were absent, I went daily about the rookery seeking opportunities to illustrate every phase possible of family and individual life, neglecting general views entirely.

I did not succeed to my complete satisfaction, but I secured a number of happy glimpses into family life, which are here presen ed.

\section{FIRST IMIPRESSIONS OF PENGUINS}

Emperors were first seen in the Bay of Whales, but we had no close intercourse with them till we moored to the fast ice in MacMurdo Sound.

An Emperor soon made his appearance. Three of us stand round him to form a group, which Brocklehurst photographs. The Emperor takes all in good part; he is quiet and dignified in all his ways, and not in the least alarmed. 


\section{MEMORIES OF ANTARCTIC DAYS}

I return to work, and a few minutes later see the poor Emperor carried on board dead. Somebody had knocked him on the head. This is a bad beginning, but so it always happens where man comes.

Emperors are the most curious, mysterious, humanlike beasts. As soon as we were moored, two of them came along. They affected to take no notice of the ship, but stayed about a hundred yards away, stolid and indifferent. They appeared to be keeping an eye on the ship, for when her position was changed a pair soon appeared. We thought they were the same.

What if these birds are more highly civilized than we suppose, and these two are deputies from the great rookery (somewhere), sent to watch us? They may have traditions of similar curious beings coming to their cities and working havoc among the inhabitants.

He is very hard to kill, and when you see one in the hands of his persecutors, who are inflicting various tortures in their efforts to kill him, you may ask yourself which is the superior animal.

I have not seen him angry or excited. Whatever is done to him he looks at you with the same mild, inscrutable eye, which yet has no suggestion of stupidity; yet he must be stupid, to our way of thinking, or we could never eatch him.

He gives the impression that he belongs to a civilization so much superior to ours that he cannot conceive that anything on two legs would hurt him. He is wrong, but all the museums in the world could go without specimens for me. 


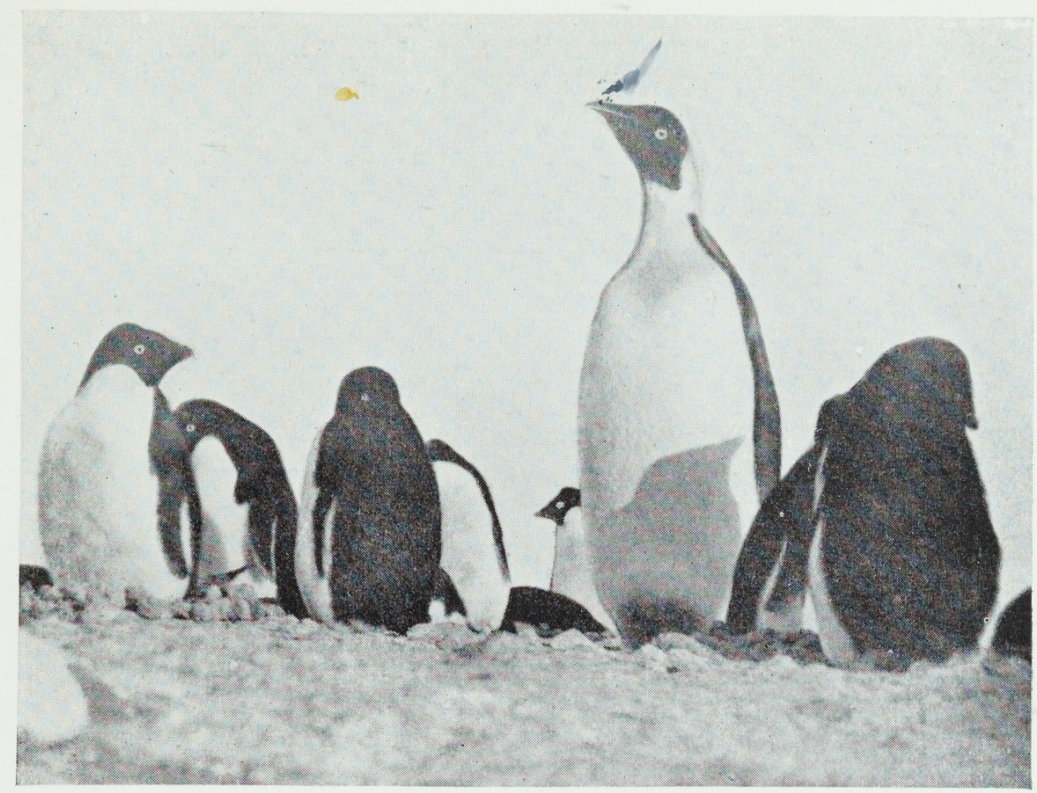

A Giant among Pigmies.

Emperor visiting the Adélie Rookery.

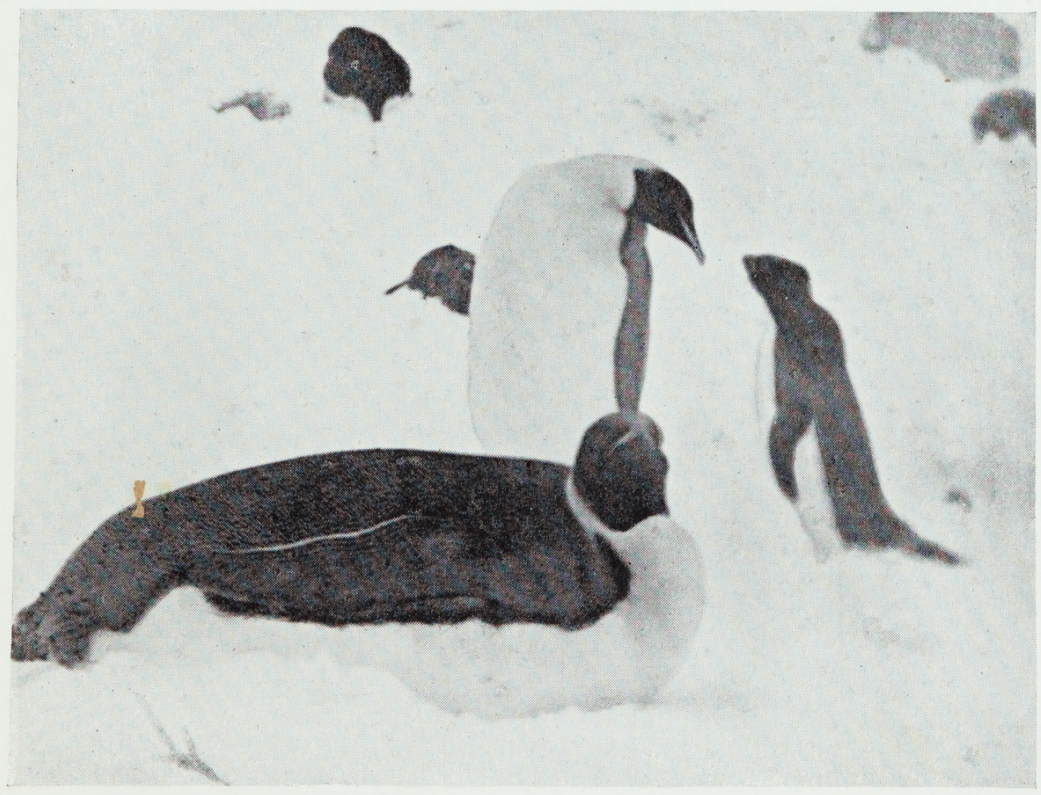

Dignity AND Impudence.

A fussy Adélie trying to pick a quarrel with a stately Emperor. 


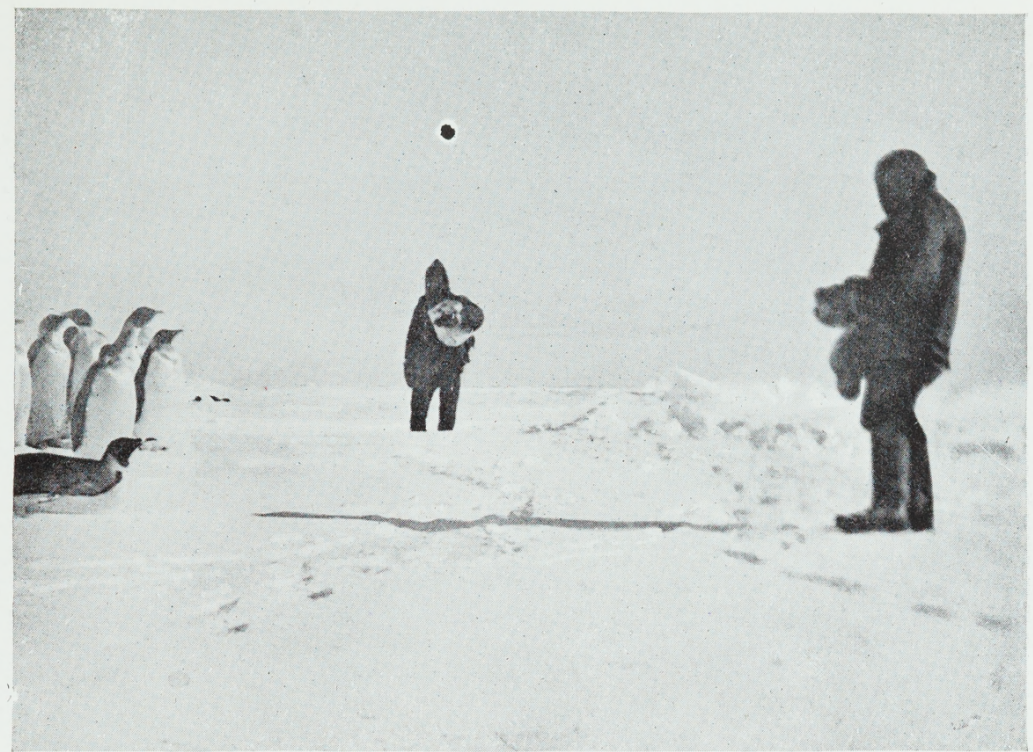

Photo by J. Murray.

The Snapper Snapped: "Don't move, Please!"

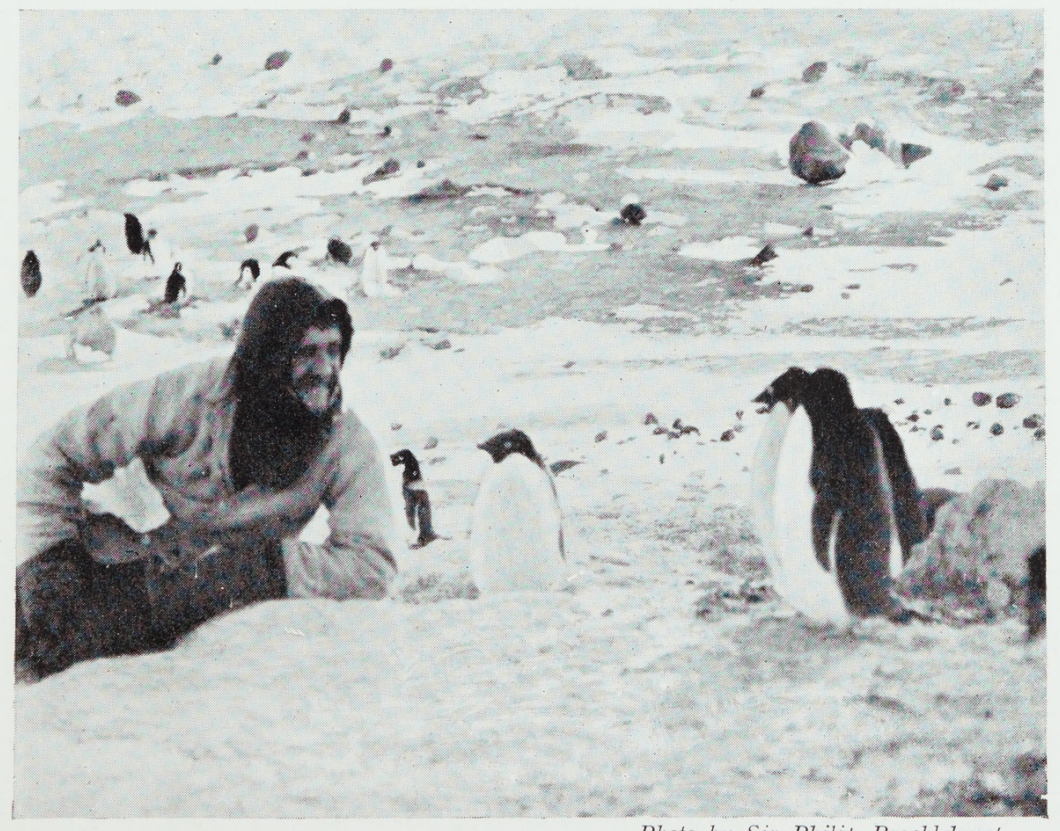

Photo by Sir Philip Brocklehurst.

Penguin and Man making Friends.

Joyce and the Adélies. 


\section{ANIMAL LIFE : PENGUINS, SEALS, ETC.}

We were amused by a party of the little Adélie Penguins, which appeared to be playing. They lined up in an even rank at the edge of the ice; one raised a flipper, apparently as a signal, and they all dived in together. In a few moments they popped up suddenly like Jacks-in-the-box (or is it Jack-in-theboxes?), alighting in the upright position, and lining up for another dive.

We had two Adélies on board. They don't seem to know fear. They are hot-tempered and will fiercely attack anything, screeching and ruffling the head-feathers into a crest, and striking out with the strong flippers. One was knocked on the head (of course!). Dunlop and I saved the other (for the time) by throwing him overboard. He did not realize the kindness done him, but bristled up and returned to attack the whole ship.

The poor little Adélie, fussy and bad-tempered and pugnacious as he is, what has he done that he should be killed? If you saw one of these little fellows, not reaching to a man's knee, facing up to half a dozen men, you would think a sportsman might concede that he deserved to live.

He does not depend upon numbers for his courage. He stands alone and, with not another Penguin in sight, defies the universe.

The meeting of the two diverse civilizations, that of the man and that of the Penguin, must lead to manifestations of an interesting kind, if they are of the kind to sadden the thoughtful. The more complete civilization of the Penguin (since it has pro- 


\section{MEMORIES OF ANTARCTIC DAYS}

duced almost perfect social order, in which there is practically no serious conflict of interests, is yet rigid and narrow, the result of instinct and long custom in a life of few and simple activities. The lower civilization of man (when considered in view of its failure to produce anything approaching to a satisfactory social order) is more self-conscious, more intelligent, more adaptable. Interests must clash, and of course it is the Penguin which goes under. For one small thing, the man will want to eat the Penguin, and will do so. The Penguin, having no experience of such dangers, does not even know to go away; does not realize what it means when it sees its neighbours killed. Possessed by its instinct to breed and rear its young, it persists in doing so at all costs.

It is possible that there may sometimes be wanton cruelty to Penguins, or disregard of their claims to be treated as civilized beings. We have not to reproach ourselves with anything of the kind, but-men bring dogs, and therein we have the origin of the tragedy of the Penguin Rookery.

As a precaution against scurvy it was necessary that we should have fresh meat. The Adélie Penguin was the only available source of supply. We found afterwards that the Weddell Seal appeared at times all through the winter, but that could not be anticipated or trusted to.

So, just before their departure, enough Adélies were killed to keep us in fresh meat throughout the winter. Their tenacity of life made this a gruesome business. Penguins may be killed in a humane 


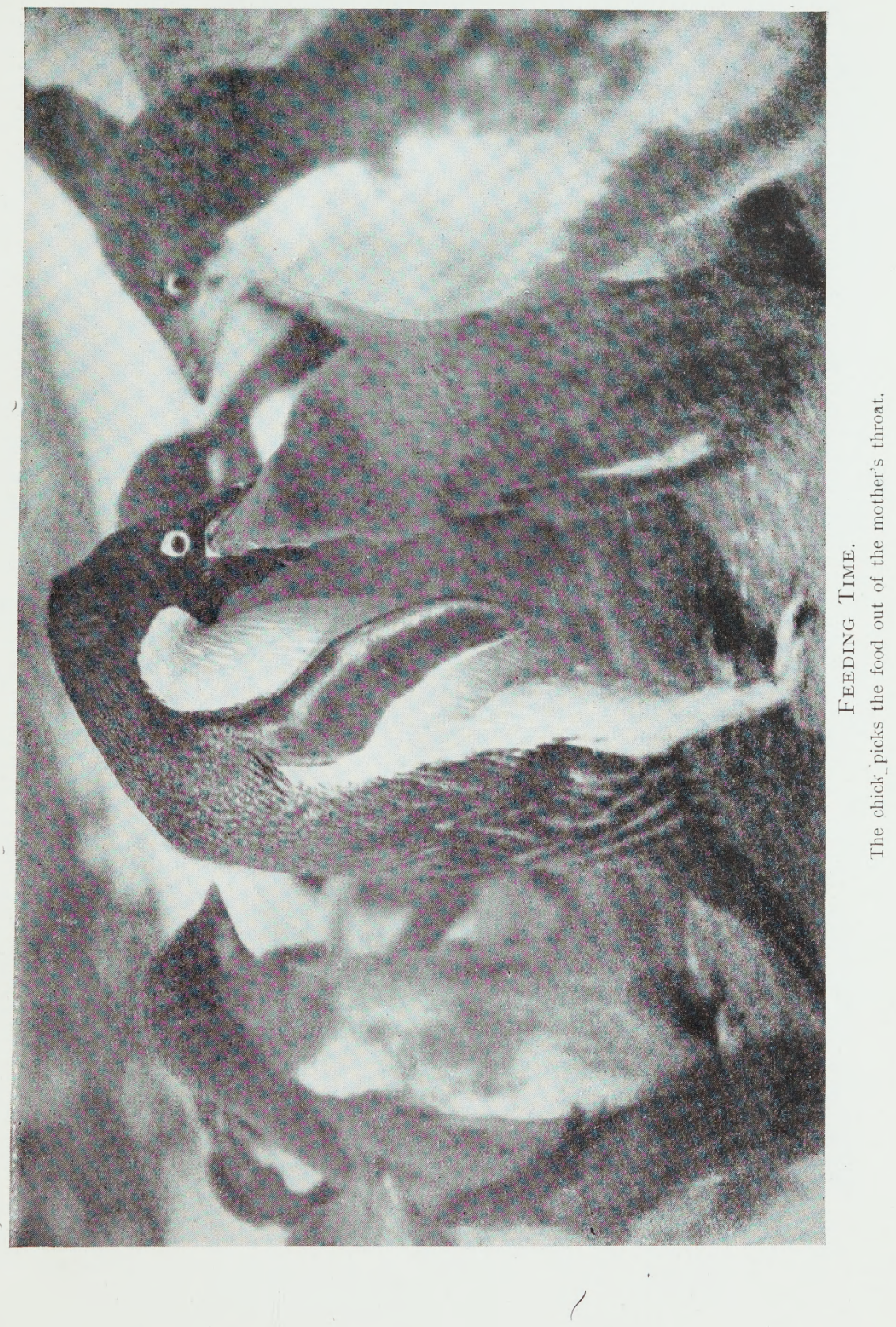




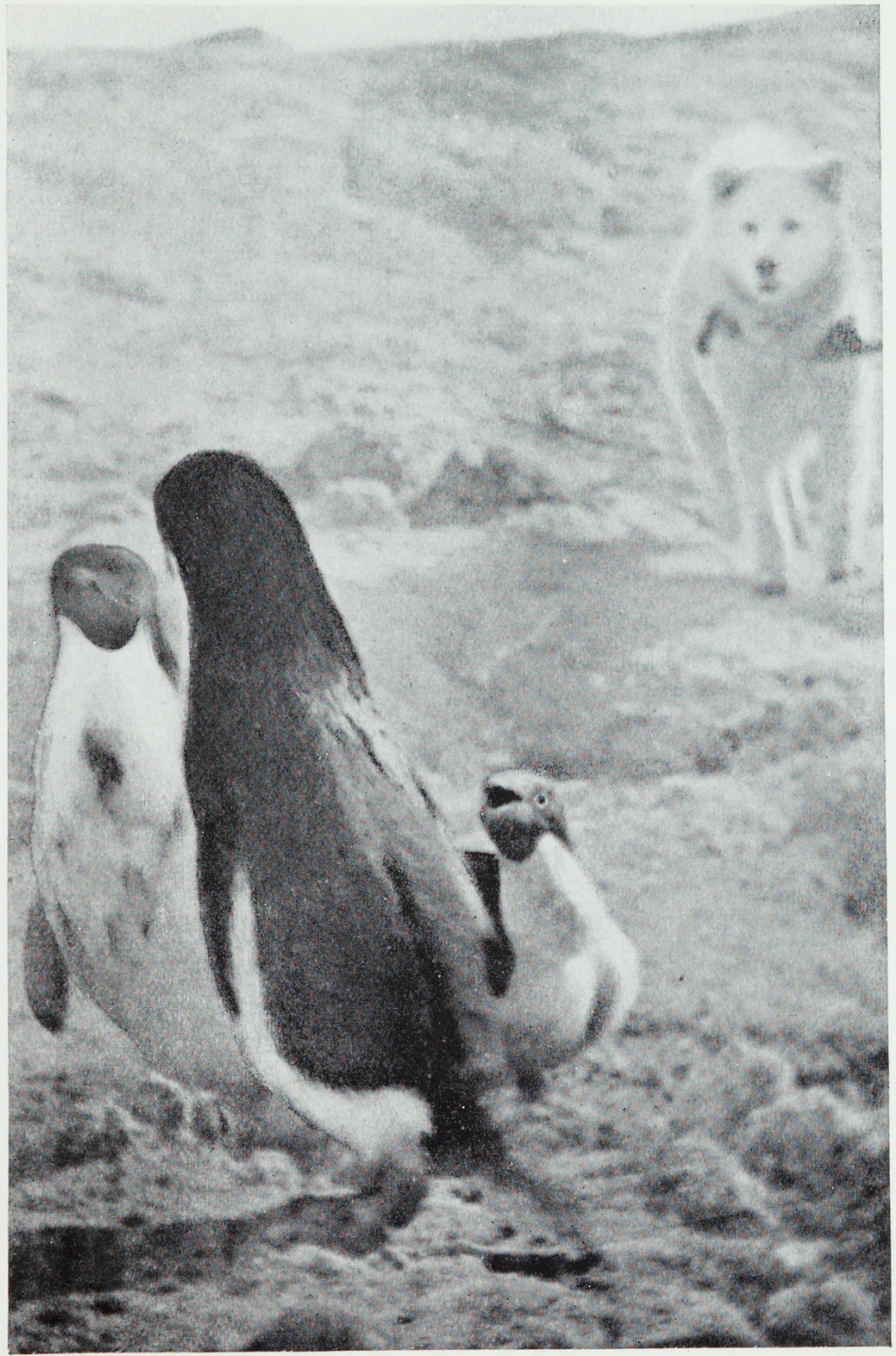

Photo by J. Murray.

Penguin Life: Danger near.

An interesting peep into family life. Danger, in the form of a dog, is imminent. The parents are too busy squabbling to notice it, but the chick, quite a small one, does, and is frantically trying to attract their notice before it is too late. 
ANIMAL LIFE: PENGUINS, SEALS, ETC.

manner when you have time for it, but when the whole year's supply must be secured at once, there is no time to be too nice. They are chased and knocked on the head with whatever weapon you have, and they are terribly hard to kill.

There is no need to give sickening detail-no doubt our slaughter-houses are as bad-but all the ghastly business is covered up from us, and we do our butchering by proxy. It is when you have to be your own butcher, and have to do this horrible thing upon a civilized being, walking upright on two legs like yourself, that you are given to think what it means, and may reflect that to live on the fruits of the earth is cleaner and decenter. However, there are no fruits of the earth in the Antarctic.

The Penguin cannot retaliate. He might desire to eat the man. I don't think so, but if he did he would be disappointed. He gets his living by swimming through the water with his mouth open, straining out crustacea between the plates that hang from the roof of his mouth, like the whalebone of the right whale, and he is not, I believe, squeamish about the feelings, or even the rights, of the Amphipods.

The Adélie's tenacity of life is astounding. From the heap of bloody corpses, which we had collected to be dressed, there would emerge, and go careering down the slope with lusty squawks, a Penguin so horribly injured that it seemed surprising that it held together, head almost severed from the body, wings or legs broken, and hideously gashed. 


\section{MEMORIES OF ANTARCTIC DAYS}

\section{FEROCITY OF THE ADELIE}

Very little notice has been taken of the ferocity of the Adélie Penguin, but here is an instance.

A man once fell among Penguins, literally-he was making a short cut through a rookery to the shore when he stumbled over a stone and fell. Hat and mitts fell off. Instantly, before he could make any effort to regain his feet, the ferocious birds were upon him, plying their powerful beaks upon his bare head like so many pickaxes.

When he eventually struggled or rolled somehow out of the mass his head was covered with wounds which afterwards swelled up to the size of eggs.

It was quite an adventurous undertaking to go through the rookery collecting eggs. After a little experience we never went on one of these excursions without long boots reaching well up the thigh. Although the birds are quite without any thought of co-operative attack, it often happens that so many of them attack you at one moment that the result is the same as if they did act in concert. You can't watch them all, converging on you from every direction, and so now and again you may get caught.

Some birds are much more pugnacious than others, and never fail to attack a man on sight whenever he happens to come within their limited range of vision. These fighters charge upon you without warning, and if you chance to be looking the other way the first thing you know some soft, fleshy part is seized and nipped as in a vice, causing excruciating pain, for they know enough to 

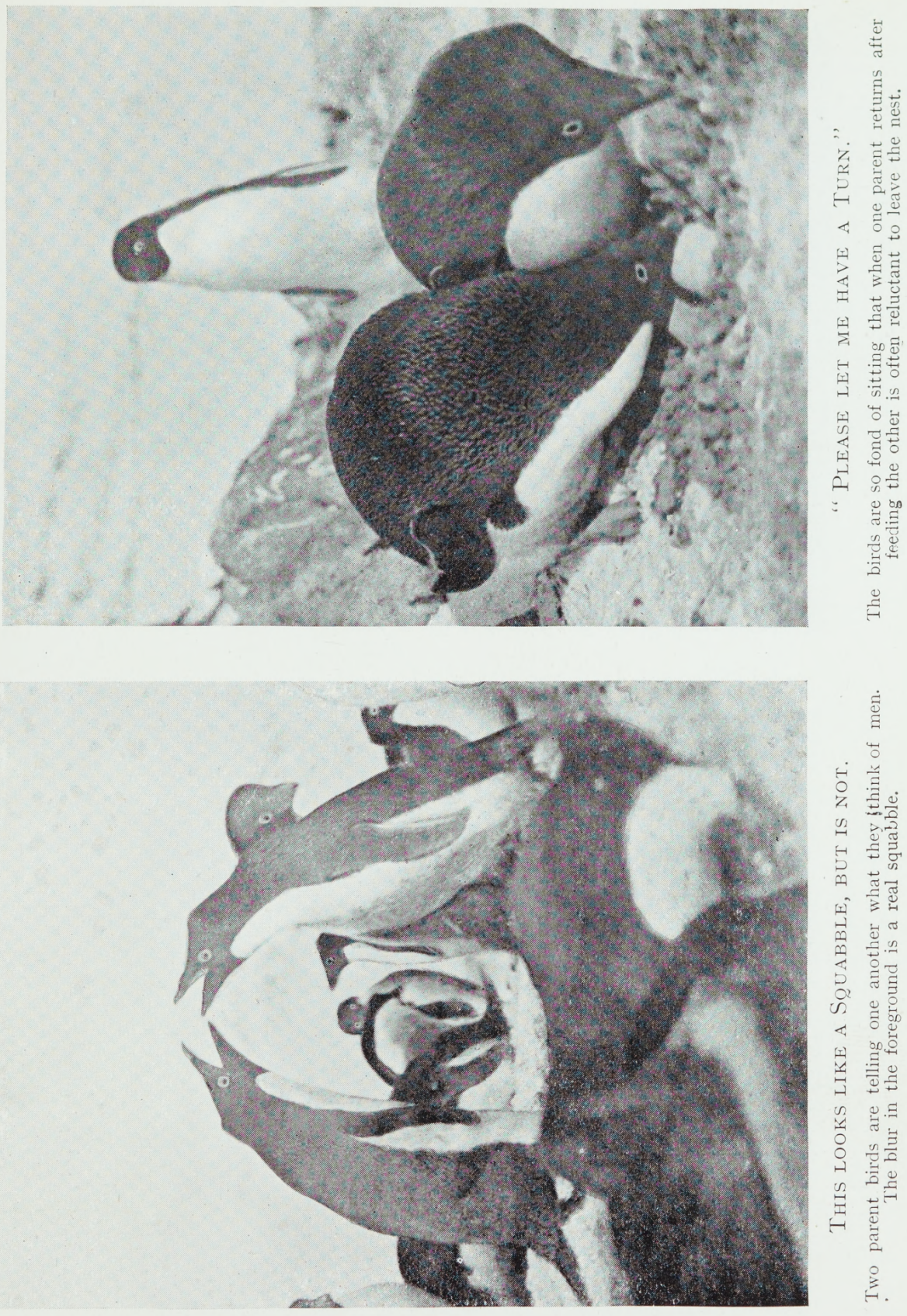


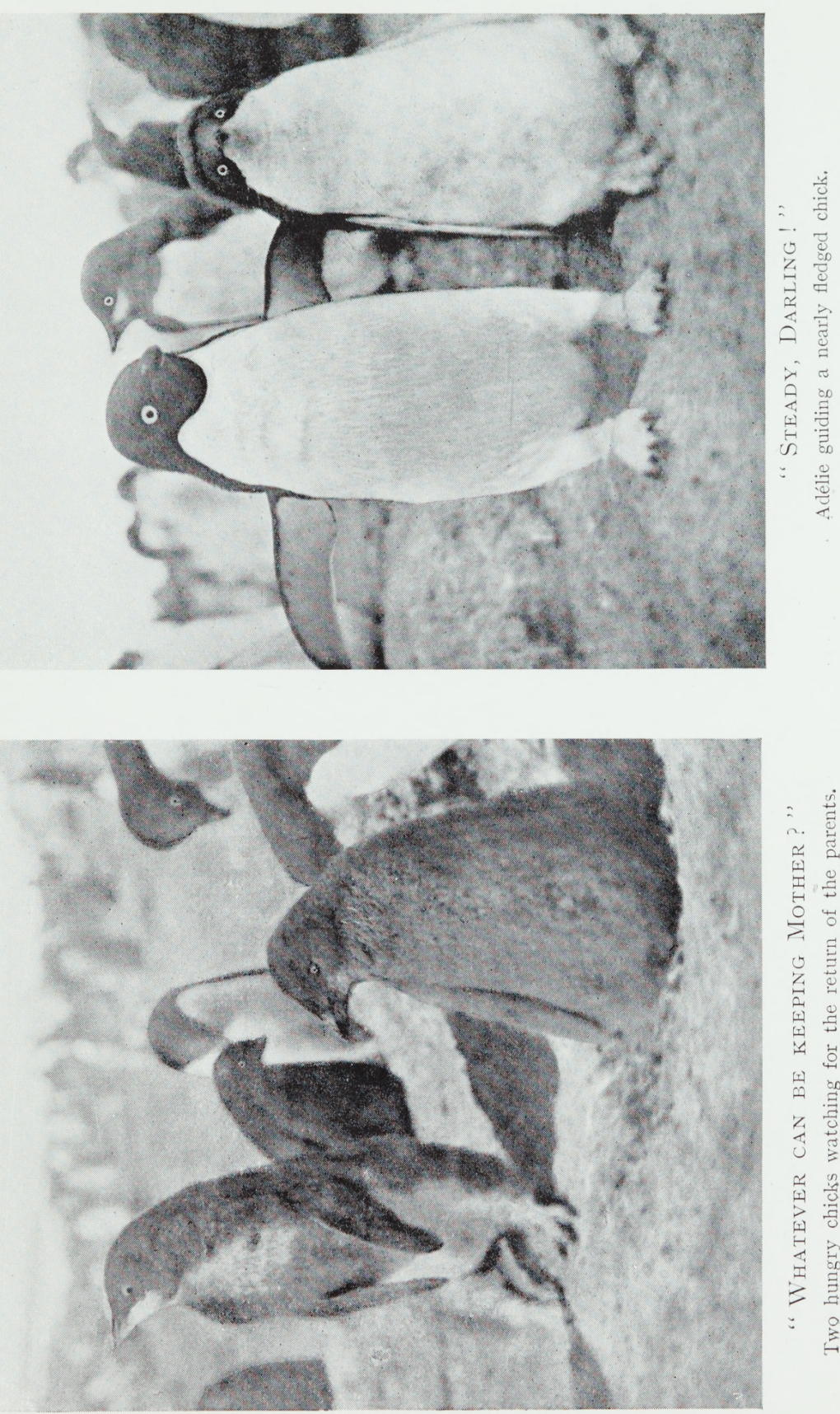

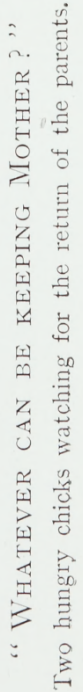



ANIMAL LIFE: PENGUINS, SEALS, ETC.

leave your boots alone and catch at thinly-covered flesh.

\section{THE PENGUIN THAT WOULD NEST ON DISH- WATER HILI}

Close by the side of the hut there arose gradually an icy hill, increasing by the discharge there of all slops and dishwater. Dishwater Hill was not the name we actually called it, but it will serve to denote the kind of hill it was.

An enterprising Adélie came inspecting the hut. It discovered this hill and it seemed to it an ideal spot for nesting. Perhaps the conditions there most nearly resembled those which prevail on its native rookery.

The spot was several hundred yards inland from the rookery. He came back several times and eventually brought a mate, "just to see the place." The mate didn't like the look of it and went away, but he was determined to nest there or nowhere, and began accumulating small stones in the usual way.

Coming and going he had to run the gauntlet of the dogs, which were usually all chained up except the young pups. The dogs were intensely interested in this Penguin, which is to say they wanted his blood. He seemed sublimely unconscious of danger, as he used to stand just beyond the reach of a chained dog.

We were afraid that he would get killed, and tried to drive him away. One day Gwen was loose, but, as there were several of us about, Gwen refrained from finishing him off. In the fight the Penguin 


\section{MEMORIES OF ANTARCTIC DAYS}

appeared to fancy himself, and think he was more than holding his own, although Gwen only refrained from making the fatal snap for fear of consequences.

Afraid lest Gwen's patience would break down, one of our number captured the Penguin and carried it to safety at the Rookery. All the way it protested in the most violent way against this interference with the fight. It wanted to fight it out, but, anyhow, it never came back.

\section{THE DOGS}

Although I have supposed that to permanent residents in the Antarctic, dependent for a living on the seals and penguins, the dog would be a disadvantage and a danger, to casual visitors like ourselves, he is a great social acquisition.

Always cheerful and friendly, and always ready for a run, when your biped companions get upon your nerves, you can go out and loose a dozen dogs and then forget all worries in a glorious scamper over sea and snow.

Circumstances required us to punish some of them severely for penguin worrying, but they never bore any resentment, or felt that they were unjustly treated. They bowed to the storm and, as soon as it was over, were ready to be friends with you.

Joyce had most authority over the dogs. He had charge of them and fed them, and taught them sledging. They had all a pure love for Priestley, who was in the habit of taking crowds of them for long rambles when most of the rest of us were 


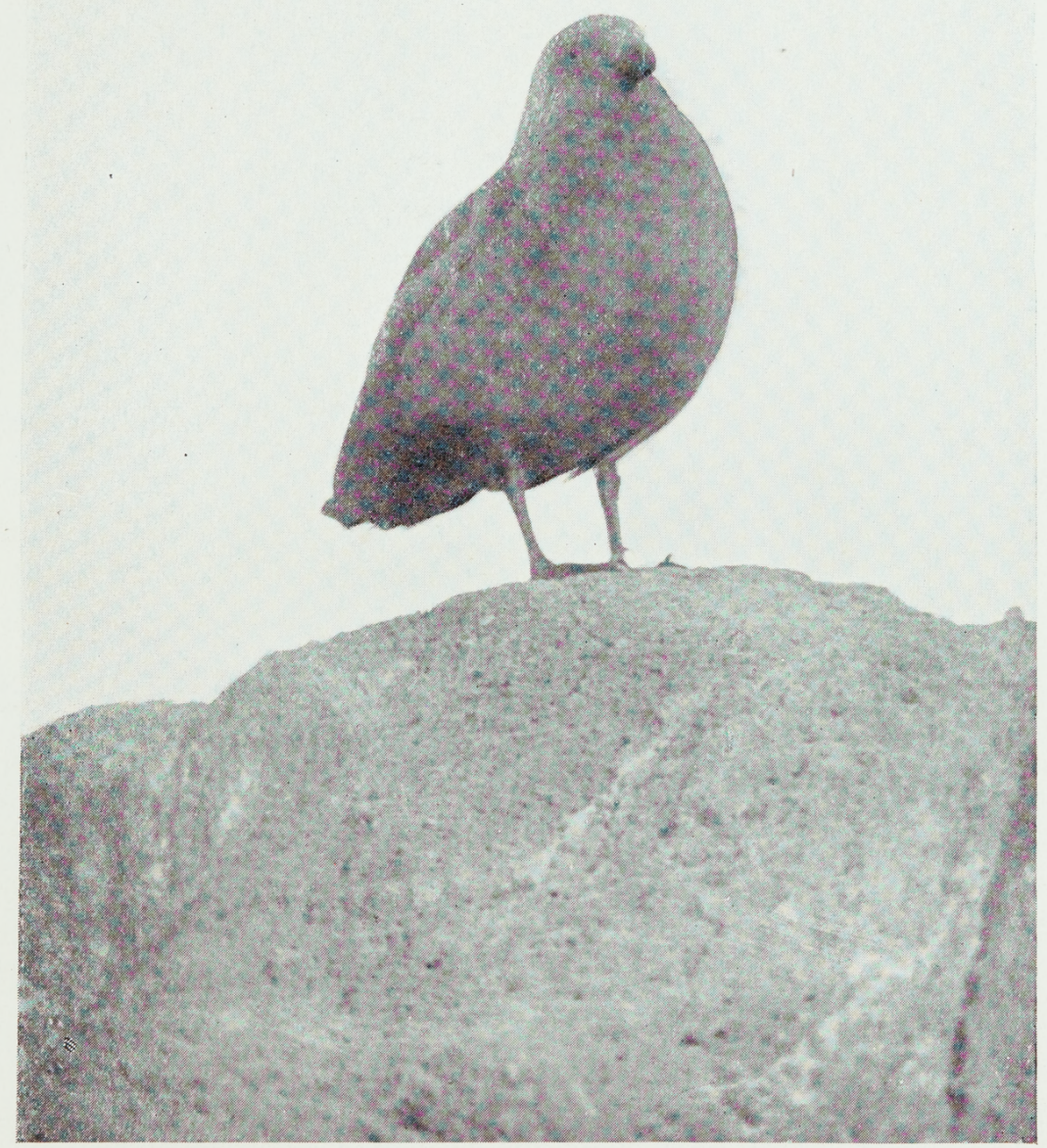

Photo by J. Murray

The Cruel Shua, the Worst Enemy of the Penguin Race. 



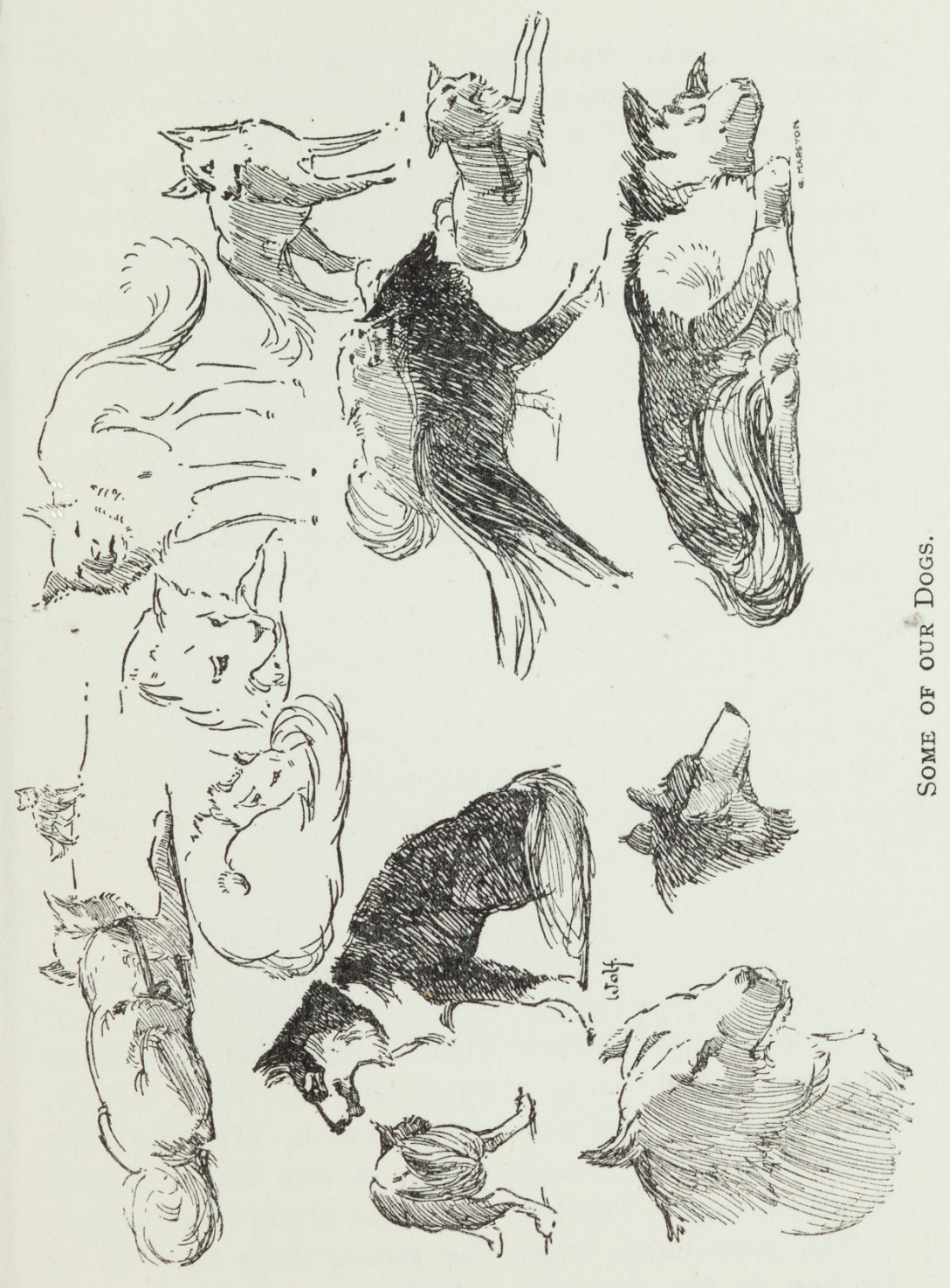




\section{MEMORIES OF ANTARCTIC DAYS}

hanging about the house. It was a common sight to see Priestley on the ground enveloped in a cloud of dogs, all playing and worrying at him.

When we made our first landing at Cape Royds, the dogs were taken on shore and chained to boulders. A slight blizzard coming on, the ship had to stand out to sea. There was no time to take the dogs on board, and no food had been landed for them. When we returned, two days later, we found that two of the dogs had broken loose. Without food, and feeling themselves deserted, they naturally became panic-stricken and strove to get free.

One of them, poor Queenie, must have come to a bad end, probably gone over the cliff into the water, for we never found trace of her. The other had made havoc in the Penguin Rookery. Scores of corpses lay about, and, most pitiful of all, many birds were horribly mangled, but not killed outright. These we had to put out of their misery, a disagreeable mercy which we had to exercise at intervals throughout our stay.

\section{AMBROSE AND EREBUS}

Ambrose and Erebus were brothers, and indistinguishable, till one discovered that if you got both dogs together and ordered them to "lie down and be kicked," one obeyed and the other didn't. So then we knew which was which, but the difficulty was to remember which it was that behaved in which way. The test could not always be applied.

The time came when the young dogs were to be broken in for sledging. Ambrose and his brother 


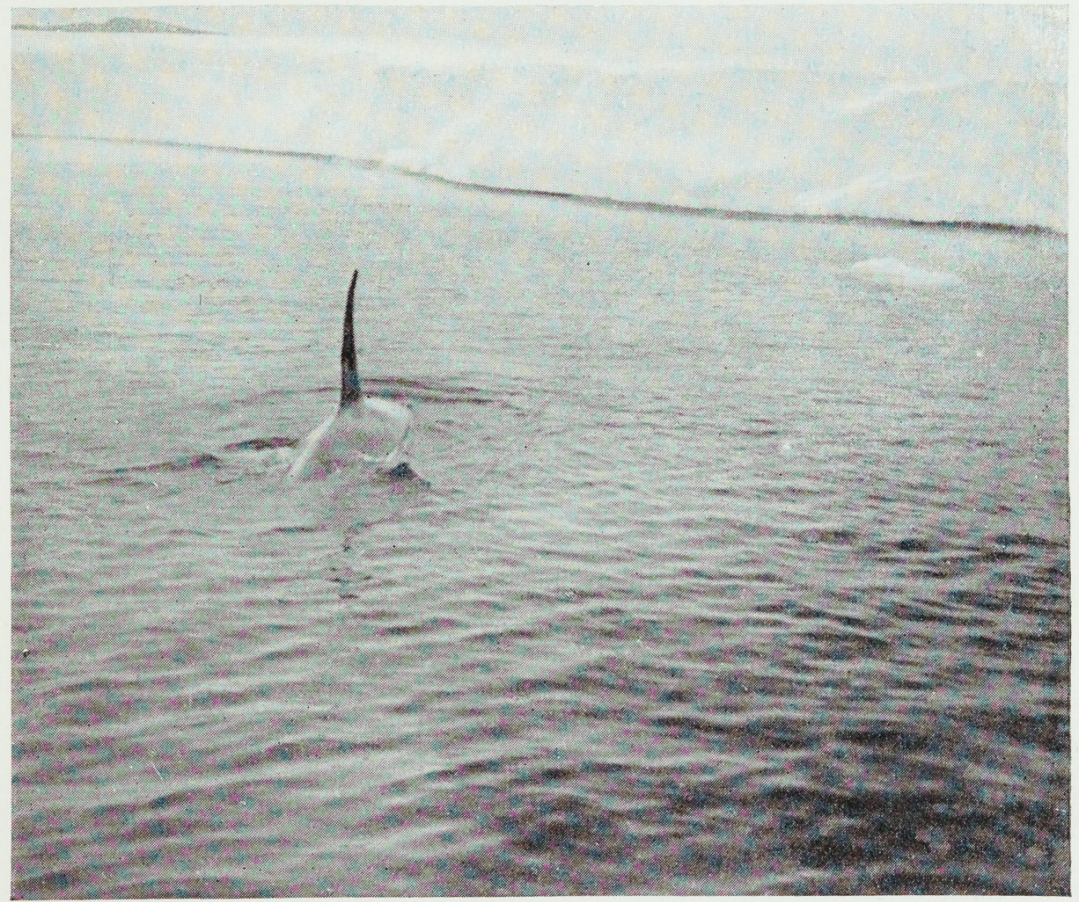

Photo by Sir Philip Brocklehurst

A Killer Whale. 



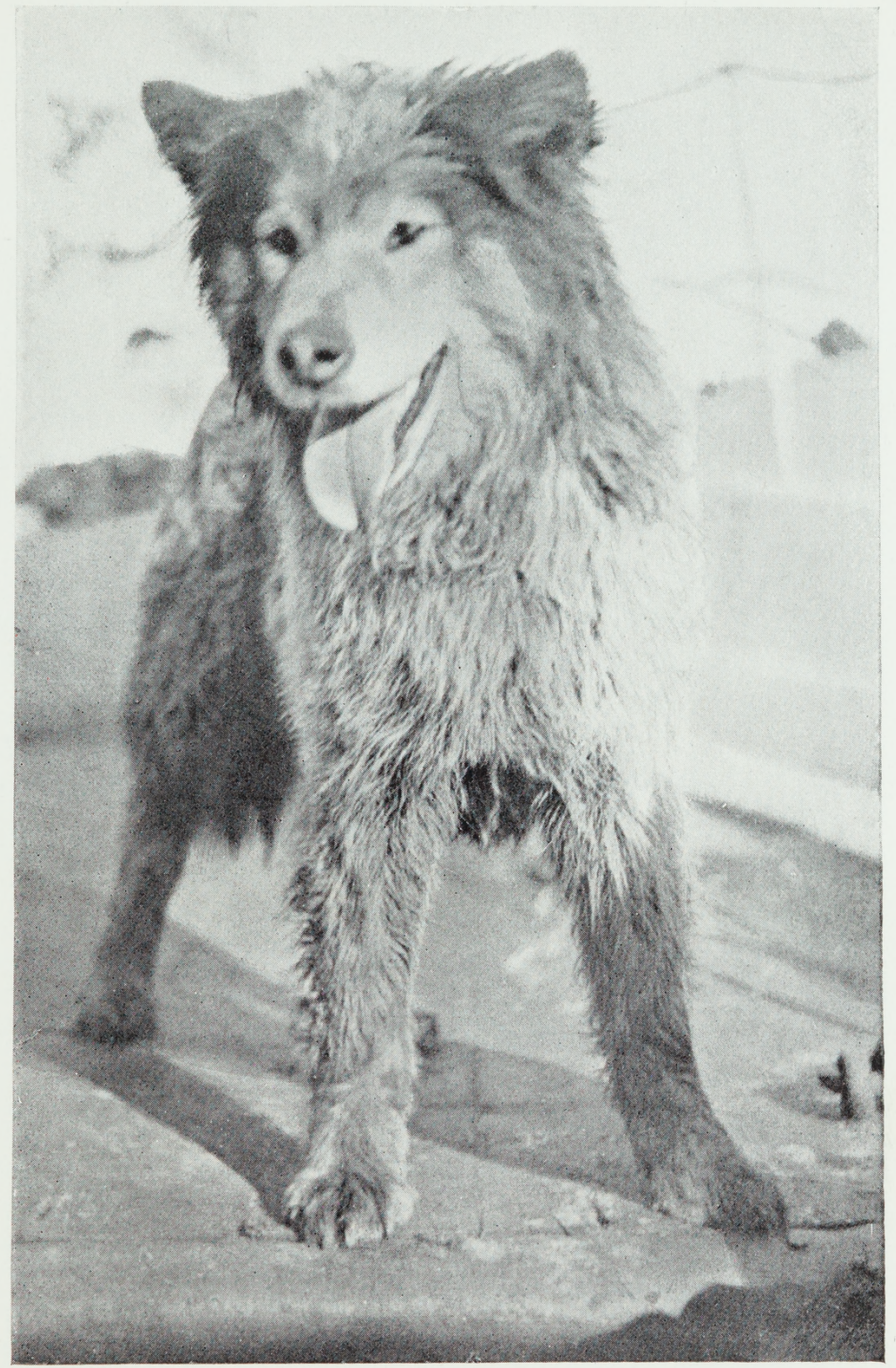

OLD SCAMP.

The contest for the Kingship was less sanguinary than it is reported to be in most teams of Siberian dogs, probably because there was nobody sufficiently nearly a match for Scamp to seriously dispute the mastery. Wolf made a bid for it, but Scamp was never really put on his mettle. 

ANIMAL LIFE: PENGUINS, SEALS, ETC.

- the name Erebus was dropped in favour of Ambrose's brother-were taken out and harnessed. The one dog at once bent himself to learn, the dog that wasn't Ambrose-I mean the dog that wasn't the other dog-refused absolutely to try. He was kicked, beaten, harnessed with the rest of the team ; he allowed himself to be dragged along, stern foremost; he allowed the sledge to go over him. He left no room for mistake; he would not work. No mercy was shown him, but when eventually serious sledging began, he was left behind as hopeless.

Then the wisdom of the dog that was or was not Ambrose became manifest; he had no kind of work to do, and remained the only dog in camp.

\section{THE TRAGIC END OF DAISY}

Daisy was a very small brown-and-white bitch, ostensibly of a very humble disposition, but with a foxy character. She was so humble and selfeffacing that when any one approached her she lay down on the ground, while still a long way off, and curled up into a perfect volute, with a look of apology for not being able any further to efface herself. She got more kicks than caresses as a result of her humility, for such servile grovelling disgusted most of us, but she was never quite cured of the habit.

Daisy was a very good mother, and successfully reared two families in the Antarctic. I forget all about her first family, but the second consisted of three interesting little beggars, named Little Wolf, 


\section{MEMORIES OF ANTARCTIC DAYS}

Curly and Yapper. When only a few days old these pups used to run out of their shelter on to the snow, with all the bearing of lions, and willing to hold their own against all the world.

When the pups were old enough to take long excursions, Daisy began their higher education. They were initiated into the mysteries of penguin and seal hunting. In her character as nursing mother Daisy was allowed her freedom when all the other adults were tied up. She looked so innocent and was so humble that we were slow to suspect her of being the ringleader in the slaughters that undoubtedly were happening. But she was caught slinking away once or twice, and at last we had to admit she was the culprit.

I believe many of the pups would have grown up fairly innocent but for Daisy's evil influence.

During the summer, when there was open sea all to the northward except when loose floes drifted in, Daisy, with her two daughters, Curly and Yapper, and old Trip, disappeared. We naturally supposed that they had gone out hunting on the sea-ice and drifted off on a floe.

About two days later I was walking a mile north of the house, when old Trip came towards me, evidently very depressed and ashamed of himself. He was so sure he would be punished that he would not at first come quite close to me. When I secured him and led him to the camp he continued quite sad.

That same night Daisy and the pups came home. Their faces were daubed with dark colour, which 


\section{ANIMAL LIFE: PENGUINS, SEALS, ETC.}

seemed to be a mixture of blood and sea-water. They were very much exhausted and slept for a long time.

They had got a scare of the sea-ice and did not go hunting there for some time. But the warning was forgotten in time, and once more she led her daughters astray. They came back some days later, but Daisy never returned. 


\section{MEMORIES OF ANTARCTIC DAYS}

\section{CHAPTER XI}

\section{YARNS OF THE SOUTH}

\section{HOW TO ALWAYS HAVE A CLEAN SHIRT}

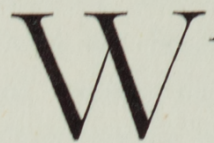

ATER is scarce in winter, and still more

so in summer. The scarcity is due to

the limits set by nature to the capacity of your stove for melting ice or snow. When the stove has to melt ice enough to provide not only the water needed for cooking and dish-washing for fifteen men, but also for watering six or eight horses, there is not much to spare for "frills"; washing, carried far, becomes "swank."

There is also a limit to your changes of linen, however generously supplied. A genius hit upon the plan whereby you can always have a clean shirt, even if you only possess two-always without washing, be it understood. You put on a shirt; in a-week or two it becomes dirty; you don the other one, and wear it till it is so much dirtier than the first that the first is clean by comparison, and you revert to it, and so on ad infinitum.

\section{MAC'S BLUBBER LAMP}

On a coasting journey the quantity of paraffin which has to be carried for cooking purposes is a 142 


\section{MEMORIES OF ANTARCTIC DAYS}

serious item in the sledge load. On inland journeys there is no alternative, you must carry it, but on the coast, where there is an unfailing supply of seal and penguin blubber, it would be a great advantage if this could be used for fuel. Mackay was the first to notice the possibilities of this, and he began to experiment.

The first blubber lamp was not a conspicuous success, but, on retiring one night, Mac lit it and put on a pot of water to boil. In the morning, after eight hours' burning, he went out to inspect. The result may be imagined when it is told that he came in and proclaimed-" Anybody want some hot water, not too hot?"

Successful blubber lamps were afterwards devised, and Mac's idea was triumphantly justified.

\section{MAC AND THE JAM-PUFF}

On baking days the cook was in the habit of making a large jam-puff, for which the chief had a weakness. This was secreted in the pantry. Most of us knew about it and respected the jam-puff when hunger drew us on the prowl into the pantry.

One evening, late, Mac emerged from a prolonged sleep and felt hungry. He made for the pantry and the first food he encountered was the special jam-puff. He knew nothing about the private preserve, and came out of the pantry with the pastry held in his mouth. At that moment the front door opened and the chief entered. They met face to face.

Coming from the outer darkness into the brilliantly144 


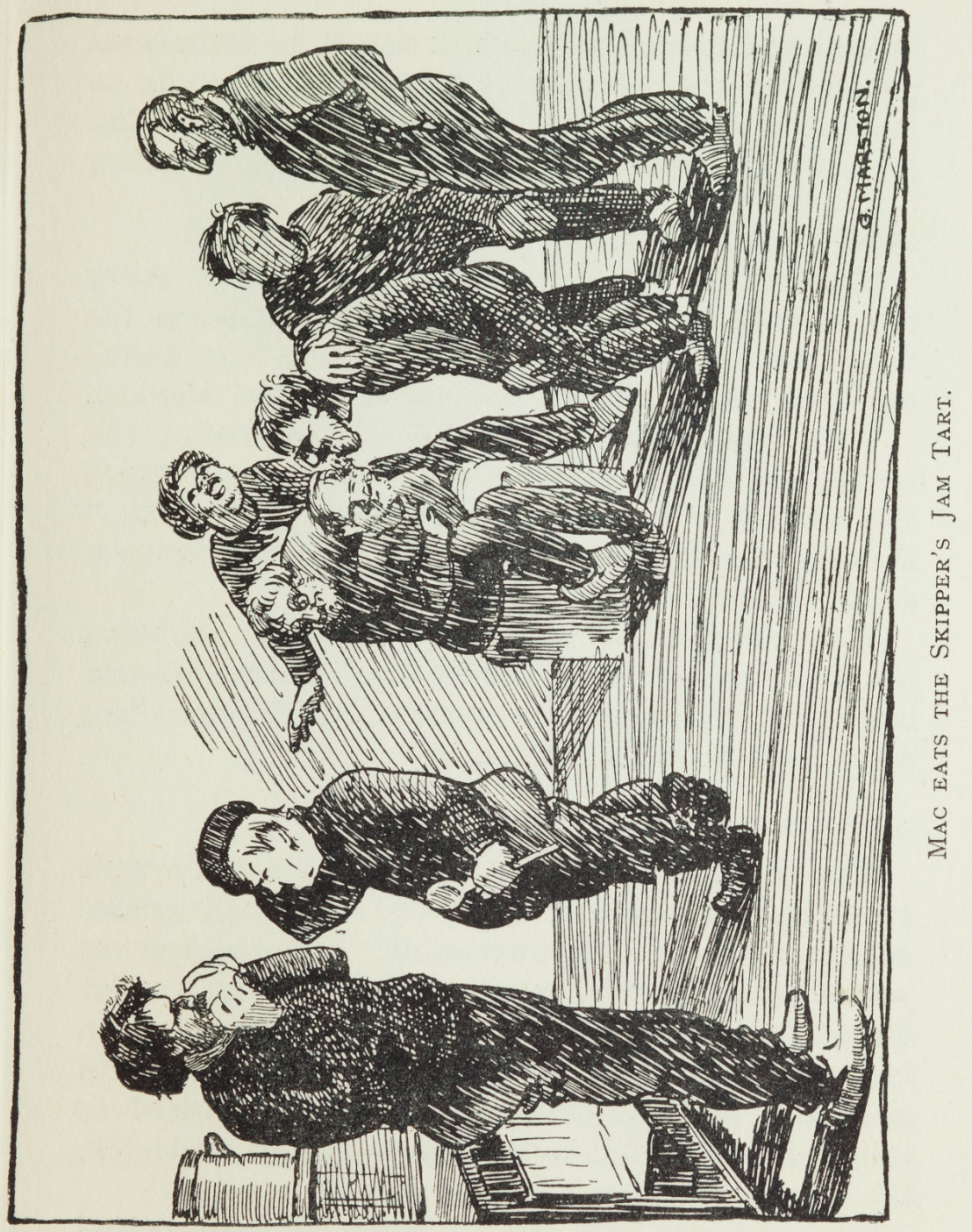




\section{MEMORIES OF ANTARCTIC DAYS}

lighted hut, no doubt the chief was as far from comprehending the meaning of what was happening as Mac himself, but everybody else saw the point of the joke, and the hut shook with the shouts of laughter.

\section{MAC'S TROUSERS}

Finding the trousers issued to the shore party too complicated for everyday wear, or being for some other reason unhappy in them, Mac determined to make himself a pair out of a Jaeger blanket.

With the assistance of the harness-maker the trousers were cut and fastened together. I don't know which of them was responsible for the "cut." Marston has here attempted to depict the trousers at this stage of their eareer.

The fuzzy cloth afforded too many alighting places for ice particles, and so the trousers gathered moisture. Finding them unsuitable, Mac cut them down into a pair of mitts.

\section{WORKING DIFFICULTIES}

The climatic conditions interfere seriously with every kind of scientific work, and frequently render certain branches of it impossible. I suppose every young scientific worker who takes part in a polar Expedition goes with an enthusiasm for certain kinds of experimental work, very desirable and creditable in themselves, which he is surprised to think all his predecessors unaccountably neglected, till he gets there, and begins, and finds why.

The biologist will dredge with an unexampled fervour, will get his dredging holes opened when 146 


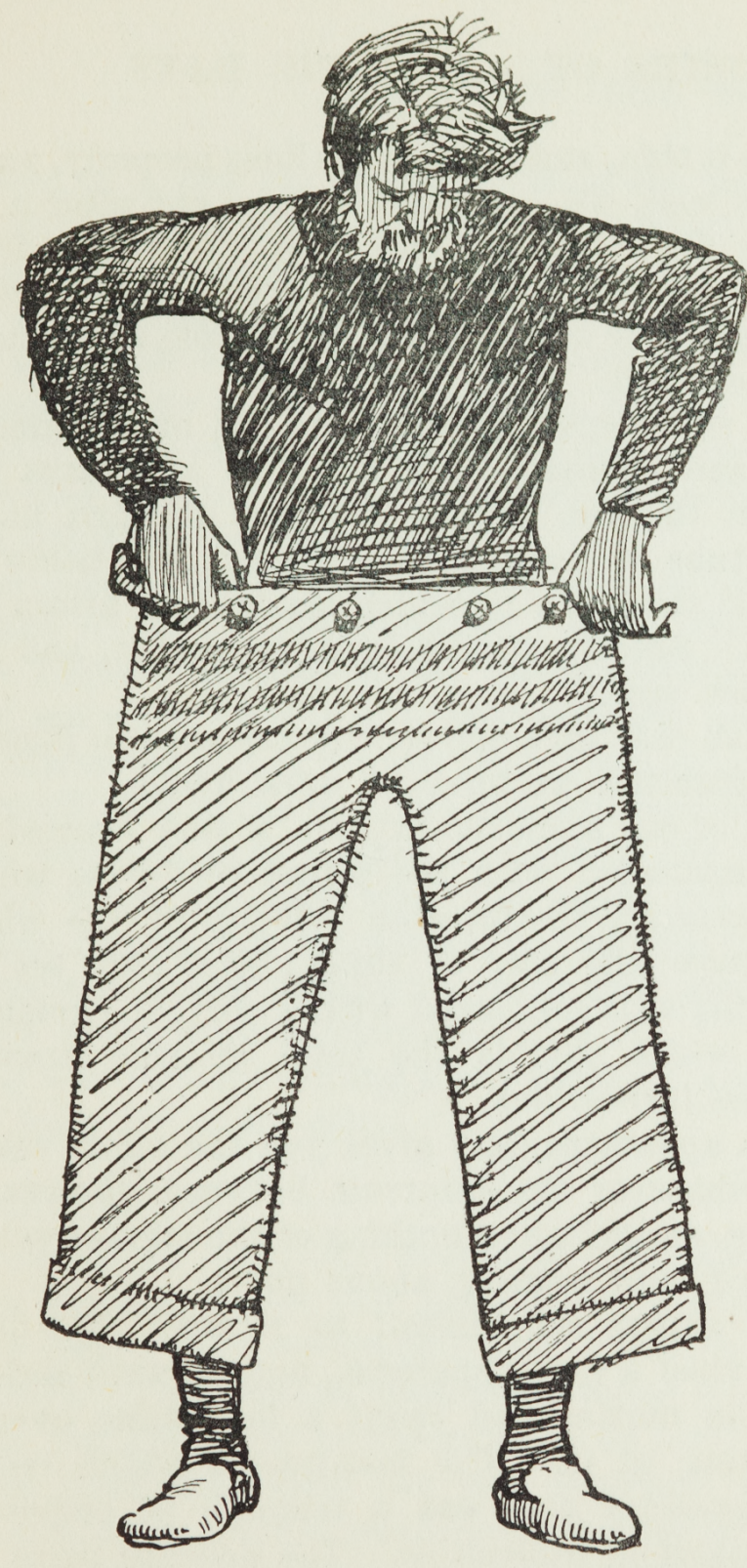

Mac made Himself a Pair of Trousers out of a Blanket. FINDING THEM A MISFIT, HE CUT THEM DOWN INTO A PAIR OF Mițs. 
the ice is thin, and arrange his lines properly, and all will go well, till-one day he goes out after a four or five days' blizzard and finds everything frozen hopelessly solid. Beginning anew, he discovers that cutting a long trench in ice six or ten feet thick is quite difficult.

The oceanographer will keep full observations of tides and currents. He fixes his apparatus in a hole in the ice, passing the line through an oilfilled tube so long that it seems well below the possible thickness to which sea-ice can attain in a season. Shortly after he goes to visit it, and finds it frozen stiff.

I shall only give one specific instance to illustrate the difficulties we have to work under.

One of our scientific experts, a very learned one, was dissatisfied with the primitive device we had for measuring the force or velocity of the windyou know the sort of thing: four cups set on a revolving axis connected with a sort of cyclometer affair, which records the total distance travelled between inspections.

This apparatus only gives you the mean velocity over whatever the intervals between observations may be, and tells you nothing of the highest velocity attained, and nothing about gusts.

Our expert set himself to remedy this defect. He devised a new apparatus, and he went seriously into the matter and spent a long time over the perfecting of it. The instrument which resulted was ingenious and was a triumph of engineering over manifold difficulties. The delicate parts were 148 


\section{YARNS OF THE SOUTH}

enclosed in a box for protection from the weather. The chief part was an ingenious adaptation of an old clock to make it turn a disc which was coated with a black substance.

A pith ball suspended by a string was to be agitated by the wind and to move a pointer which traced a curve on the blackened surface of the disc. The whole was to be placed on a post on the top of a small hill close by the hut.

The contraption was finished and everybody watched to see its inauguration. Alas! the Antarctic climate claimed a say in the matter. It would not work, or only in a very qualified manner. As a matter of fact it proved that if you baked the clockwork part of the machine in a hot oven for two hours, wrapped it in a cloth and ran to the top of the hill where the post was, you might get a tenminutes' record, if it did not happen to stop sooner.

Thus was about a month's work and much ingenious brain work rendered of no avail.

This was only one among many pieces of abortive work from the same cause.

\section{PREJUDICE}

Prejudice is hard to overcome. I hope the officers against whom this little yarn is told will forgive me, if they recognize it, for I will mention no names. They are all reckoned among my best friends, but the story is too good to be lost.

Some little time after the ship returned, somebody, looking through a telescope, imagined he saw, away far south, one of the sledging parties return- 


\section{MEMORIES OF ANTARCTIC DAYS}

ing. I set out, accompanied by three of the ship's officers, towards a high cape a few miles distant, from which we might see them better.

Before going, I had word privately conveyed to our cook on shore, telling him that there would be company to dinner.

I knew he would exert himself to get something really fine for the credit of the shore party.

It was a glorious walk over the sea, with a stiff climb up on to the top of a volcanic pillar at the end of it, and then a ramble, or scramble, over some miles of ragged moraines to the hut.

The expected sledging party proved to be mythical -no doubt we saw penguins miraged up to an unnatural height.

I reached the hut in condition to eat unquestioningly anything in the shape of food put in front of me, and I proceeded to do so. But there was no questioning the excellence of the repast, the cook had justified his reputation. We had all the delicacies of the country : penguin roast, penguin stew, fried seal's liver, penguin eggs, preserved from the nesting time by the simple expedient of keeping them in a box on the floor of the hut, where it is always below freezing point.

The local dainties are not very varied, but of course we had various examples of our cook's art not peculiar to the Antarctic.

For some time I was too busy to pay any attention to the guests - in that climate there is no need to press people to eat. But, my first pangs of hunger allayed, I noticed that they were not eating-the 150 


\section{YARNS OF THE SOUTH}

first course, roast penguin, I think, still on their plates, untouched.

They admitted that they did not care for penguin roast (three healthy young men, mind you). We helped them to stewed penguin-same result. Still unsuspecting, we offered them our tit-bit, fried seal's liver-"No, thanks, we're not hungry." (Liars!)

Beginning to have a glimmering of the truth"You'll have boiled eggs, then?"-" No?"

Then we knew! Accustomed to the ship's luxuries-salt horse, jugged hare, kidneys, curries -all tinned, mind you (a long time tinned) - they could not stomach our coarse fresh meats-Emperor breast and so forth.

I'm sure the cook felt a little bit hurt as he rose from the table and hastily fried some tinned sausages which the ship had brought from England, and then they found their appetites and ate heartily. And there was more of the despised viands for us natives, which is always something on the right side-and we helped them to finish the sausages, too, just to show there was no ill-feeling.

\section{GETTING AT THE "POWERS THAT BE"}

When fifteen men are living crowded together in one room there has got to be a great deal of give and take if things are to run smoothly. Think of it, shut up for a year or more in close and constant contact with people you loathe! Or if it isn't so bad as that, most of us have some little ways which are offensive to some of the others. You must endure 


\section{MEMORIES OF ANTARCTIC DAYS}

such things, or, if your feelings get the better of you, you have just to settle down again somehow.

Little tiffs occur on the best regulated expeditions, the best of friends cease to be on speaking terms for days at a time, in rare cases for weeks or months. I'm sure we must wonder afterwards what it was all about.

Under the conditions obtaining on an expedition no exception will be taken to any proceeding on the part of some, innocent in itself, merely because it happens to be annoying to some one else, if it does not infringe on any of the fundamental rights of explorers.

Suppose you want to turn in, and you find somebody has already occupied your particular pigsty. You don't turn him out, or make a song about it; you look for somebody else's unoccupied bunk, and turn in there.

During the winter music was one of the greatest ameliorations of our lonely condition. We had a splendid gramophone, and, contrary to expectation, we did not tire of hearing the same things over and over again. I wonder if Harry Lauder has any conception of the happiness he spread in that desolate land by his cheery laugh and humorous philosophy of life.

We had cheerful songsters among us-Marston, Mackay, Wild-who frequently enlivened an evening for us with chanties, and folk-songs and other things. If anybody were not in a mood for music he was free to go and bury himself. The general good came first. 


\section{YARNS OF THE SOUTH}

One of Mackay's favourite songs is worth quoting. He only knew one verse and the chorus. It was called "Jamie Shaw," and goes like this :-

A queer wee chap wis Jamie Shaw, Him, an' his wife, an' his mither-in-law ;

They keepit a baker's shoppie in Dundee.

His heid wis big an' his feet wis sma',

But his hert wis the boldest that ever ye saw,

And his hicht wis only fower feet three.

But tho' he wis sae terrible wee,

A maist determined chap wis he,

For killin' folks and battles he'd nae fears.

His spirit wis sae bold,

It widnae be controlled,

And sae he went an' jint the volunteers.

\section{Chorus.}

Mairching in the mornin', musterin' in the mirk, Paradin' on the Sawbath, when the folks is gaun tae the kirk;

Jamie's jint the volunteers,

A pair o' tartan breeks he weers,

Mairchin' on tae fame and glory.

It happened one night that the chief, who was to go on night watch at midnight, had retired early to try to sleep. There was a chanty concert going on that night, which prevented him from sleeping. Although he had a few square feet of space boarded off and dignified by the title of his "Cabin," he could hear all the noise through the match-boarding as well as if he had been in the big room. But he 


\section{MEMORIES OF ANTARCTIC DAYS}

made no complaint; he was used to that sort of thing. I do not remember that we heard even any suppressed swearing coming through to show that he was disturbed.

At the moment of which I am telling it was not a chanty that was on, but a song entitled, I believe, "The Two Grenadiers," which Putty sang with great gusto, while Mackay accompanied with hideous noises produced by banging on some tin can or other.

I wasn't in all this, but, happening to pass through the room, I observed a venerable eminent scientist wringing his hands in ecstasy and with a diabolical grin on his face. "Murray," he leered, in answer to my questioning look, "one does like to get at the powers that be, eh!"

\section{A POSER FOR THE BIOLOGIST}

We used to amuse ourselves at table by posing one or another with problems, usually concerned with navigating in high latitudes. Suppose we had reached the South Pole, situated, as it is, on a boundless, featureless plain of snow. Your tracks are completely obliterated during the night by a snow storm, and you have broken your compass and let your chronometers run down. How would you make your base?

The following was aimed at the Biologist. Suppose you have been a long time absent on an Exploring Expedition. Stores are beginning to run low. The stock of preservatives is completely exhausted. Just at this juncture you discover a 


\section{YARNS OF THE SOUTH}

unique animal, of a class by itself, with no live relatives at all and its only connections of any kind in certain obscure creatures extinct since palæozoic times ; an animal of the utmost importance in elucidating the evolution of all existing animals.

The only thing on board that could possibly be used as a preservative is a bottle of whisky, just the quantity for an animal of the size. But it is the last bottle of whisky; the last bottle of any kind of drinkable liquid on board, and you can't hope to make a port for six months yet. What would you do?

But that was a silly problem; in fact, it wasn't a problem at all. The only thing possible to be done is to keep a very full record of the creature, with drawings, measurements, and a careful dissection to trace out its internal structures. What else could you do?

But one of my compatriots was heard to mutter, "Whit wey wis yon bottle left?"

\section{SWANK}

When we sailed for the Antarctic, the word "swank," in its modern acceptation, was unknown to me. Doubtless I was behind the times. When we returned it had taken its place in classical literature. During the Expedition we became familiar with both the word and the article.

No man or woman is free from petty personal vanities; we all swank in some way, if it be only in being free from swank. It is mostly harmless; we all smile at the little vanities of our friends. 


\section{MEMORIES OF ANTARCTIC DAYS}

An Expedition, by giving human nature a chance of untrammelled manifestation, is an excellent opportunity for the development and observation of swank. But it is a subject which I must treat very lightly, for it is a curious fact that the little vanity which produces swank makes the man blind on that side. The man with the keenest sense of humour does not see the joke if it touches his particular vanity.

So I must be careful to avoid offence and be easy on our various swanks-how one swanks as the bluff sailor, another on polar dress (needlessly polar), on sledging flags, on Alpine posing.

Our artist made an excellent group of caricatures entitled, "Fourteen good men and true." It was curious to go about the house after its publication and notice that every man thought all the caricatures splendid, except his own.

There was a man came to the Antarctic; young, very, very young ; and quite new to ice and glaciers. A number of us were walking about on a glacier, not at all a dangerous one, but still you had to keep your eyes about you and be wary of crevasses. Two of us found a crevasse, in the usual way, by going partly through, with that sickening upward jerk of the heart which accompanies this experience even after it has become tolerably familiar. We threw ourselves forward and crawled off the treacherous snow-roof, shouting out, "Crevasse!" in warning to the young man following. "Where?" shouted he, and to our amazement he strode towards the crevasse and tried to fall in, thinking most 
probably of future yarns. "Come away," said Armitage to me, and we left him. If he would fall down a crevasse, let him at least do so unseen. You have more respect for crevasses after meeting them in real life.

\section{MISTAKEN GOOD-HEARTEDNESS}

When men visit unsophisticated communities such as the rookeries of Penguins in the Antarctic, the meeting has unfortunate results for the natives. The animals are perfectly adapted to their surroundings; they know all about their natural enemies and how to escape from them.

We cause serious interference with their normal lives; introduce grave new dangers. They cannot adapt themselves, their instincts are too well developed. Penguins and seals could avoid all danger by going away somewhere else, but of course they do not do so.

The Emperor Penguin is slow to suspect evil of a creature going erect on two legs like himself, and appearing civilized.

The Adélie Penguin, with only himself to think of, is quite timid, at least after a little experience of men, but when he has a nest to defend he becomes bold as a lion and defies the whole universe. He has no fear and will stand up against any odds. A solitary Adélie would stick to his post if his whole nation were exterminated save himself.

After their families were off their hands the Adélies fled in great fear when men came near them. They could not escape to sea, because the moult 


\section{MEMORIES OF ANTARCTIC DAYS}

comes on just after nesting. It appears to be a law that they must not enter the water while moulting; perhaps they'd catch cold !

When we first landed the Adélies were getting towards the end of their nesting. The chicks were large and some of them were beginning to cast their original thick down.

At this period whole provinces of the rookery may be seen without a single grown-up; the parents are out at the fishing. The chicks crowd together for protection against the fierce skuas. At this time they have established the communal system, pooled all their parents, and each chick attacks the first old bird which comes near.

One day we observed our tender-hearted artist busy among the penguins. He carefully carried an unwilling chick from one part of the rookery to another; then returned and carried another over. He had noticed these orphans looking lonely on one of the hills of the rookery. Now where he took them they were regarded as intruders and received with hostile beaks. All the chicks are alike orphans at this stage in their lives. In this instance, I believe, the chicks were in the end admitted to the larger community. After chicks are big enough to leave the nest and flock together for protection, a bird can be adopted into any community by simply plunging into the mass; then nobody can tell him from another.

Our artist was the hero of another similar exploit. He noticed a seal on the sea-ice, and, fearing that the dogs would hurt it, tried to drive it into the 


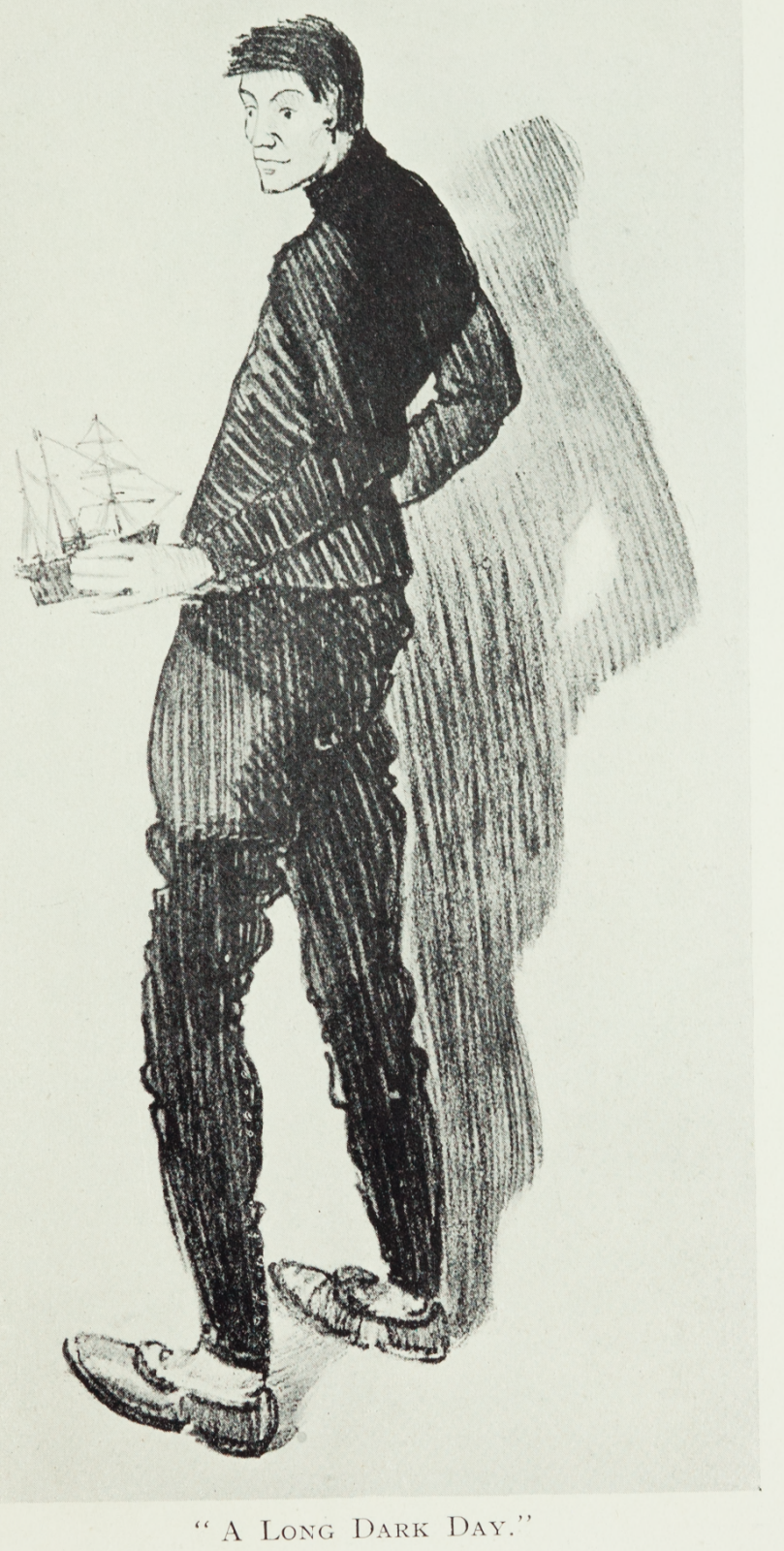



sea. It was curious in this case to watch the working of its intellect, or its instinct. All history tells that the only dangers which threaten the Weddell Seal are in the sea; chiefly killer-whales, perhaps also sea-leopards. So in danger it seeks safety on ice or land.

So the more Putty frightened the seal the harder it tried to get away from the hole through which it had come up.

\section{THE ARTIFICIAL SWEETS !}

Tins of sweets, which we owed to the thoughtfulness of Lady Shackleton, were issued to each man. The supply was limited, and they were of the kind called, I believe, Bull's-eyes. They were sticky, glassy things, printed in black and white stripes.

The supply was running low. Some were hoarding them; some were lavish and spendthrift with them, leaving their tins at the disposal of all and sundry.

Marston carved some wooden balls and painted them black and white in imitation of the real ones. He dropped one surreptitiously in tins here and there, and watched the result.

He first tried Armitage, who was sitting by the fire eating his few remaining bull's-eyes. He took one and crunched it, then another. Then he came on the wooden one, and tried to crunch it in vain. He took it out, looked at it, glanced around to see that nobody was noticing, and put it in the fire.

Putty next offered one to Mackay, holding three in his hand, two real ones and the counterfeit, partly 


\section{MEMORIES OF ANTARCTIC DAYS}

covering the real ones with his thumb to make it easier for Mac to choose the wrong one. Mac hooked out all three and, laughing at Marston for the way he had done him, began to eat. He crunched the first, and then his teeth jarred on the wood of the second one. He tried again, and then took it out and looked at the piece of wood, for he had by this time chewed all the paint off.

\section{A STRANGE CATCH}

When the ship came down the second year, she was on one occasion moored to the fast ice, and I was pottering about the edge with a net, looking for biological spoil.

Priestley, who was always interested on these occasions, came to lend a hand. He saw something a little larger than the shrimps we usually caught, and exclaimed-"Hulloa, Murray, here's a big Pteropod for you," and he tried to fish it out.

After some trouble we got it out on to the ice, and, on unfolding it, it proved to be of cloth, and nothing else but Priestley's own sledging flag, which he had never seen before. It had been sent down on the ship, "among other things."

It was perhaps not so strange, considering what queer things happen at sea, that the flag and other things should get cast away in that manner, but it was curious that its owner should be there at the moment and should fish it up as a biological specimen. 


\section{LAST DAYS IN THE SOUTH}

\section{CHAPTER XII}

\section{LAST DAYS IN THE SOUTH}

\section{THE RETURN OF THE SHIP}

T THEN the winter is over and the work of the Expedition approaches completion, the return of the ship is eagerly looked for. It seems nothing could be more desirable; she will at least bring letters, re-establish connection with the living world, practically terminate our exile, and before long carry us back where the earth is green and friends are.

So for some weeks before the Nimrod could be expected one or other member of the reduced population of the Main Camp would climb High Hill, taking Armitage's good telescope, in the hope of descrying her in the distance.

There we would lie at times of leisure for hours, on the sheltered side of the peak if there was a breath of air, accompanied by some dogs and with a biscuit or so in the pocket, and there we would sometimes drop off to sleep, comfortably warmed by the hot sand.

And the Nimrod never was espied and watched making her slow way through the ice to us; but one day, going out after having " afternoon tea," there 


\section{MEMORIES OF ANTARCTIC DAYS}

she was, already moored to the ice edge, some half a mile away.

And the return of the ship was not at all as anticipated-for one thing she brought no letters, and gave us the sad news that possibly two men had lost their lives trying to bring the mail to us, as related elsewhere.

The return was more like an unexpected douse of cold water than the joyful event we had so long looked forward to.

There was one bright spot in the gloom. All our old friends among the officers had returned, thereby proving their devotion to the Expedition under extremely discouraging conditions. There was no mistaking their welcome. But, "A new Pharaoh had arisen who knew not Joseph!" Alas, there was a strange skipper!

\section{INCONVENIENT KINDNESS}

We were so busy among our friends that for some time we paid no attention to what was going on on board. When we recovered somewhat from the excitement of the meeting, we noticed a huge pile of cases on the ice, and the willing seamen, under the direction of the mate, were still heaving them over in frantic haste.

We were puzzled! Some little comforts our friends in the world had no doubt sent us, but what could this great mound of boxes mean? Then it dawned upon us-our ever-enthusiastic mate was carrying out the tradition-we were the distressed 


\section{LAST DAYS IN THE SOUTH}

explorers, they were the rescue ship-he was succouring us (good old Davis).

But when the ship departed for a short cruise, leaving the heap of boxes on the ice, we had to pay for all this succour in desperately hard work. For we had to haul all these stores over the half-mile of rotten ice to the shore, as the sea-ice was breaking up. Thus instead of a quiet read of our expected home letters, we had to start in on a hard spell of sledge-hauling, conveying ashore masses of stuff we had no earthly need for, no doubt including loads of tinned meats, in this land where we had unlimited fresh meat!

It seems ungrateful, doesn't it ? But then, as you see, we paid for the kindness in hard work.

There was an amusing sequel to this episode. After toiling for hours sledging our fresh supplies to the shore, we got the last sledge load in to the icefoot, and then knocked off work from sheer exhaustion, and went off home for a rest and a feed. The ship had gone away long before. When we next went down to the shore, a great stretch of ice had broken off from the ice-foot, carrying our loaded sledge out to sea. There, by the irony of fate, the floe carrying the sledge was encountered by the Nimrod as she cruised in the Sound.

\section{THE LOST MAIL}

The adventures of our letters are involved in those of Mackintosh and his companion, which are related in the Heart of the Antarctic. They are here told from our point of view. 


\section{MEMORIES OF ANTARCTIC DAYS}

When the ship arrived early in January, 1909, and we went on board, after the first interchange of greetings with old friends, we were asked, "Has Mackintosh arrived ?" The question surprised us, for how could Mackintosh arrive except on the ship ? Then we were told how Mackintosh and a companion had left the ship two days before, in order to bring our letter-bag to us over the sea-ice. This horrified us, for we were at the northern limit of the fast ice and only a few days before we had seen open water as far as eye could reach towards the north. The ice now filling the Sound was a very loose pack, just drifted in. Travel over it was impossible.

The Captain was urged to take the ship out as soon as possible in the hope that the men might have made their way ashore at Cape Bird. That same night a light southerly breeze opened out the pack, and we urged instant departure. There was, however, considerable delay before the ship left Cape Royds, and we soon found that the ice was returning.

After narrowly escaping being driven on shore near Horseshoe Bay, we escaped into deeper water, but were immediately invested in ice, which scarcely slackened during the nine days that we remained among it. We were caught in a great eddy of the pack, too dense to allow us to steam through it.

We appeared to be imprisoned for an indefinite period. It was only after some days that we discovered the drift setting north, and began to entertain hope of getting release in that direction. Often 


\section{LAST DAYS IN THE SOUTH}

we thought of the two poor fellows who had been put on to floating ice in their enthusiasm to do us a favour.

One day there was severe ice-pressure; the immense field had brought up against the west shore of the Sound. In an instant we saw all around immense cubes of ice spring up and pile themselves on the floes. The ship creaked and groaned; there was a short while of intense anxiety, and-she lifted; we were saved for that time.

Not long after the pressure slackened and we escaped, away between Beaufort Island and the Nordenskiold Ice-Barrier. At full speed we steamed past Beaufort Island and approached Cape Bird, the only spot where the lost men might have landed. We steamed along, close in shore, scanning the immense penguin rookery. We were just passing the limits of the accessible shore, before reaching the region of high cliffs were no man could land.

Just at the last point I perceived a small speck of unfamiliar green, seized a telescope, and saw that it was a tent, sure enough, and alongside was a sledge. But the tent was in ribbons; there was no sign of life; it was obviously a deserted camp, some time deserted.

Davis quickly got a boat lowered and went ashore, and, after packing all the things, returned. He found a note saying that, tired of waiting, they had left to try to go overland to Cape Royds on the 11th (it was now January 16). And Davis brought the mail bag, which they had not been able to carry. 


\section{MEMORIES OF ANTARCTIC DAYS}

As we slowly made our way among the loose floes towards Cape Royds, and saw the hideously crevassed glacier filling the entire valley between Mount Bird and Mount Erebus, we gave up all hope for our companions. And as I read my home letters it was with the belief that our friends had lost their lives in trying to bring them to us.

We reach Cape Royds; two men walk out over the sea to meet us. One is, obviously, Roberts; the other is a stranger. One at least of the men must have got through safely. Soon we heard the amazing story and knew that both were safe.

\section{ALMOST A TRAGEDY}

It was to be our last day on the Antarctic shore. After weeks of anxiety, we saw the Nimrod's whaleboat nearing the shore, and long before we could distinguish its occupants, Wild's stentorian voice proclaimed, "All's well!" We knew that Shackleton's party had returned.

Then followed busy hours of packing and despatching our various belongings. The ship was anchored in the bay, only a few hundred yards from the ice-foot; the two whale-boats plied to and fro and quickly finished the work. There was a fresh breeze and it was cold, but there was nothing to hinder the loading.

The hut was emptied of everything portable. The door was nailed up and a message fixed to it for the next explorer to come that way. We left 166 


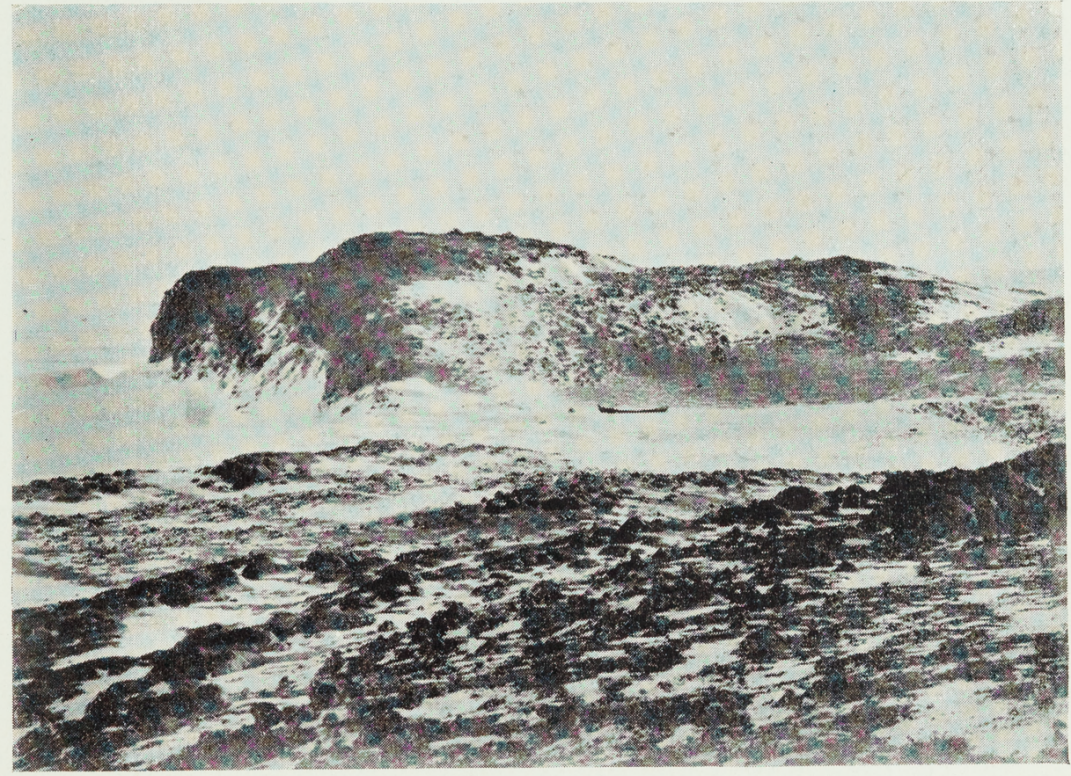

Almost a Tragedy.

Under the Cliffs on the left was the scene of this incident. 



\section{LAST DAYS IN THE SOUTH}

it without any regret or the smallest desire to look back at the old familiar home. We were going "home."

One boat loaded up and went off; the other remained to take the last of the men and the dogs. Everything had to be lowered over the ice-cliff, twelve or fifteen feet in height. It took a long time to get the dogs embarked. The wind was freshening all the time, and a bit of sea got up. We were on a lea shore. The waves rolling in had undercut the ice, exposing the rocks below.

When most of the dogs, and all the men except four had been lowered into the boat, the storm had risen to about half a gale. Joyce then declared that it was dangerous for any more to enter the boat, and Marston, Priestley and Roberts decided f to remain with him.

Mr. Harbord was in charge of the boat. We shoved off and rowed towards the ship, expecting with our four oars to reach her in a few minutes. Just then an oar broke. We learned afterwards that all our oars had served for a year as rafters of a hut, and were brittle. With three oars we were hardly better than with two, and we were immediately driven back close to the cliff. With a spurt we got out a few yards. Looking out, we saw the ship steam out of the bay. The gale was too much for her. There was no hope in that direction.

We were in a very little bight, hardly more than a hundred yards across. If we could round either point we would be safe. If we could pass the cliffs 167 


\section{MEMORIES OF ANTARCTIC DAYS}

of Flagstaff Point, we would get into shelter and be able to make the beach at the rookery; if we could get further into Backdoor Bay, we would find a low ice-foot on to which we could scramble. We tried first one way and then the other, but the wind blew full into the bight and we could not get out. Several times we were driven right in against the cliff and under the great overhanging shelf produced by the undercutting of the wave, but each time we managed to push out before the next wave, which would have crushed us against the overarching ice, rolled in.

When we first shoved off we had seen the four men left behind make off towards the hut, supposing us to be all right. We imagined we were deserted; the ship we could just see, far off. The spray which was splashing over us had covered us with thick, glassy coats of sea-ice. Those who weren't rowing had hands partly frozen. Two men were on each oar, and they were getting feeble.

On one of the occasions when we were driven against the cliff, I caught a glimpse of Marston's face peering over. We were not altogether deserted. If anything could be done from the shore, it would be done. For a long time before this we supposed we were as good as dead, but, at the sight of good old Putty's face, hope was renewed. If the boat were once capsized or smashed, it was little those on shore could have done. They might, with ropes, have pulled up one or two, but in that icy sea a few seconds numbs the strongest man.

The rope to which the boat had been made fast 168 


\section{LAST DAYS IN THE SOUTH}

still hung over the cliff, but limp and useless to us without some one on shore to tauten it. We had got some distance from it in our struggles; could we make it in our exhausted condition? $\mathrm{Mr}$. Harbord gave the order to try. We had to get opposite the rope and let the sea carry us down on it. The sailors strain towards it. We drift rapidly down on the rope; the four men on shore pull it tight; one of our men grabs at it-and misses. Again we are in under that hideous shelf of ice, but again we shove out before the arrival of the incoming wave; another straining spurt; we wear up to the rope again, Harbord springs forward and seizes it and-we are saved. Dick Nodder climbs the rope hand-over-hand, to assist the party on shore, and the disembarkation cheerfully begins. A light rope is lowered to haul the men up by, each man assisting himself by pulling on the mooring rope! It has to be seen to that the two ropes are clear of one another before hauling up. The first man to be pulled up had an unpleasant experience; his head was like to be sawn off. The ropes hanging over the cliff appeared to be clear, but on top one made a turn round the other. As he went up his head was drawn in between the cliff and the mooring rope, which was sawing up and down over the jagged edge as the waves rolled in and receded. Harbord sang out, "lower away" in time, and the rope was put right. These incidents are only amusing when you have just been dead and comealive again. Soon all were safe on shore and we hastened to the hut, where Roberts had hot cocoa ready for us, 169 


\section{MEMORIES OF ANTARCTIC DAYS}

and soon all was forgotten, as we crowded round the stove and passed the night in song and story.

How long the struggle lasted I cannot tell, but it seemed hours. 



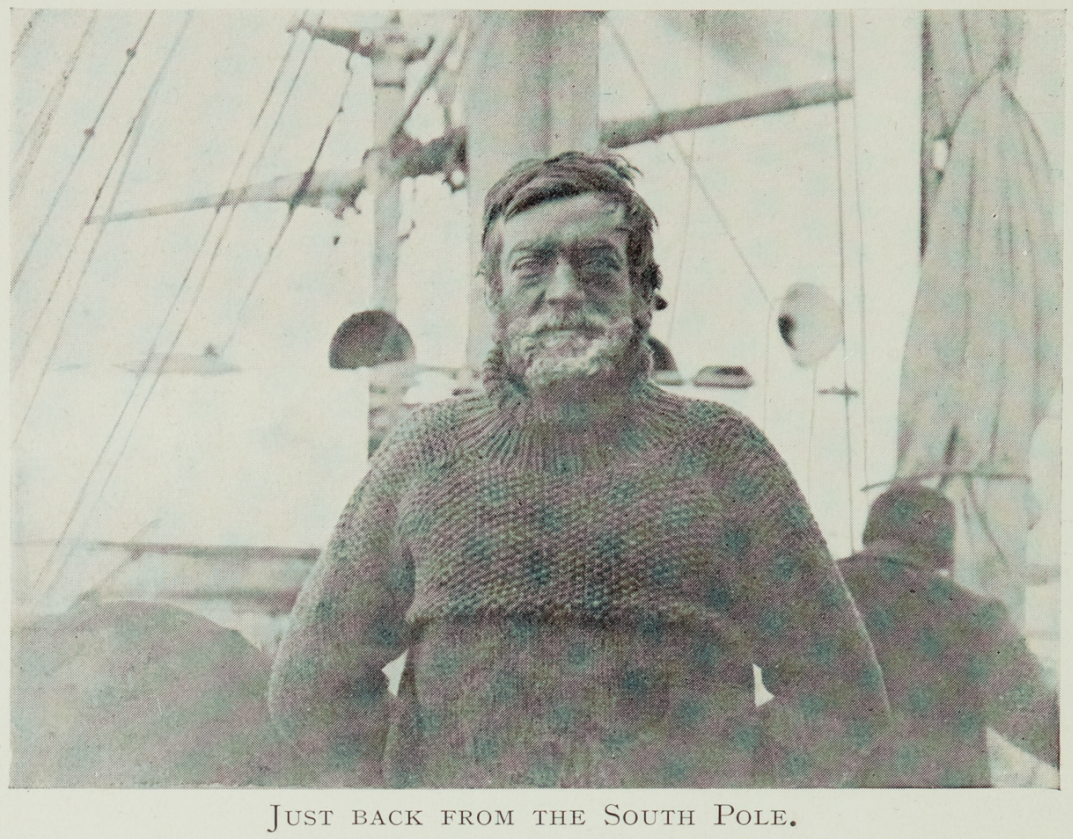

This tramp became in after life the famous Sir Ernest Shackleton. 


\section{THE RETURN TO CIVILIZATION}

\section{CHAPTER XIII}

\section{THE RETURN TO CIVILIZATION}

N the very day on which eight of us narrowly escaped drowning, as related at the end of Chapter XII, the Nimrod picked up Shackleton, with the party which had gone to meet Adams and Marshall, and then steamed northward, "Homeward bound."

A few hours later we passed our long winter's home, Cape Royds. There is no homely feeling towards the place now. It looks hideously bleak and dismal, and there are the overhanging ice-cliffs, with the cruel black rocks showing beneath, where only a few hours before so many of us expected to finish our earthly pilgrimages.

And see-the whale-boat from which we escaped, which was moored to the cliff, has sunk. Let us away from the place! Soon Cape Royds is left behind and we enter the open Ross Sea-and away for New Zealand-and home.

This day has been looked forward to continually during the long exile, as the culmination of all our efforts; when, our attempts made, we know we must abide by such results as we have achieved, and return to the land of men. 


\section{MEMORIES OF ANTARCTIC DAYS}

Now that the day has arrived we take it calmly enough. We are "homeward bound," but " home" is many, many thousand miles and many months distant.

Let us hurry over this last phase of our Expedition, with a few glimpses. We want to get home and have no time to enter into detail of this return journey.

What a time it takes to get to New Zealand! We lie about the deck, not unhappy. The terrible strain of the anxiety over the failure of the plans taken for the relief of Shackleton is lifted by his arrival, hale and hearty. Have not many of us just been snatched from seemingly inevitable death? These are occasions when trifling annoyances seemtrifling.

And thus we get to New Zealand.

What does it feel like to get back to civilized life after fifteen months in wild parts with only a few companions? In contemplation it seems a most marvellous, incomprehensible thing, which it will take a long time to get into the way of.

Our first landfall was on the South Coast of Stewart Island. It does not count, for we were primitive men on an uninhabited coast-but it was green, and warm. Never have I seen such simple, joyous abandonment to pure delight in nature.

Next day we had a glimpse of the world when we entered Half-Moon Bay. It was strange to look over the side of the Nimrod at the launches that came alongside, and see-women, and people whose clothes were not all rags. And then we got to Lyttelton, and disembarked, and were right in it. 


\section{THE RETURN TO CIVILIZATION}

People often remark to me how strange it must feel to be back in civilization after the long isolation in the snowy solitudes! Not a bit of it! Why, I can assure you that three minutes after you go alongside in the first port of call you find yourself sitting in a-tavern, resuming your old habits as if you had never been out of practice, and the whole dim voyage forgotten!

And next thing you know you are in the grip of the obsession of "mails"-newspapers take longer to resume their hold. You have lost all track of the world's history, and, even if you try, you haven't an idea what the papers are talking about.

At Lyttelton we all left the ship, which went home with only her officers and crew. We separated into many little groups and trickled round the world by various intricate channels to London.

\section{THE SAILOR MAN}

When I went down to see old friends on the Nimrod, just after she reached London, a smart-looking sailor came up and addressed me by name, and shook hands. I didn't know him, but there were many changes in the crew when the ship made the second trip South, and I imagined he must be one of the newest comers, whom I hadn't had time to get familiar with.

As I rummaged about the ship, poking into all the old familiar corners, he accompanied me, and his reminiscences of incidents in which I had taken part convinced me that he must have been there. "Do you remember, Mr. Murray, when you and Mr. 


\section{MEMORIES OF ANTARCTIC DAYS}

Marston did such-and-such a thing ?" I remembered, but still no glimmering of recollection of him came back to me.

A considerable time afterwards I met Marston, and he began to tell me of the sailor who went over the ship with him, and indulged in reminiscences of the time when they were down South together. Eventually we learned that the man had never sailed on the Nimrod at all, but presented himself on board when she was on exhibition, and by using a plausible tongue, and dressing in sailor fashion, by sheer brass and sticking to it, became recognized as official guide. He must have primed himself well on the facts by pumping the real sailors, and he must have had a very good memory.

\section{THE LOST GRANITE}

Mackay had collected a large block of granite in the Antarctic as a souvenir. He took great pride in his " rock" and carefully nursed it back to civilization.

Whether he risked it on the Nimrod or tended it himself through all the vicissitudes of a protracted and much-broken journey through New Zealand, Australia, India, France, and possibly other countries, I have not been informed. In either case it would travel something approaching to 20,000 miles, and, by whatever route it travelled, it reached London in safety, and was taken charge of by its owner to be conveyed in a cab to his hotel.

After surviving all the dangers of a sledge journey 174 


\section{THE RETURN TO CIVILIZATION}

and of much intricate sea-voyaging, the granite was lost in London, being forgotten in the cab.

\section{THE SCATTERING OF THE BAND}

When you go exploring you learn something of what naked human nature is like. It is inevitable that when thus exposed to one another in their true character some of the members of the smallest party will not like one another; they are essentially incompatible. For the same reason exploring begins some of the strongest friendships possible on earth. You are under no illusions about your friends; you know them just as they are, at their worst and at their best.

It is satisfactory to reflect that of our little band the greater number would like nothing better than to all gather together and go out upon another quest, under the same leader.

They can never, alas, all be brought together again ; there has been one break in the circle; one, the most honourable of gentlemen and truest of friends, is gone.

Three of our men, Wild, Priestley and Mawson, are even now continuing their work in the Antarctic. Day has just returned from the Antarctic ; one is in Australia, another in Ceylon; three have since been to the ends of the earth and returned.

Tarry not too long, Shackleton! 


\section{CHAPTER XIV}

\section{CHANTIES}

\section{By G. E. Marston}

HE sailor has a reputation for singing a good song or leading a rousing chorus, which he

1 perhaps deserves, and for the landsman there is a glamour about the sea and the life of a sailor which will always make songs of the sea popular; yet the usually accepted idea of a typical sea song bears little or no resemblance to the songs actually sung at sea, and the sailor's version of "A Life on the Rolling Wave" usually ends up with abuse for the man who wrote the song.

There is a type of sea song, however, with which the landsman is not generally familiar, known as the Chanty, which owes its existence to the necessities of the sailor's calling. Chanties are the working songs of the sea.

Many of these have been handed down by word of mouth through generations, some of them dating back certainly to the reign of Queen Elizabeth. Now that we are in danger of losing them, together with what is perhaps the most beautiful work of man's hand-the sailing ship-efforts have been made to preserve these haunting melodies, but the atmosphere amid which they were sung and which 176 
is an essential part of their beauty, can never be retained by black notes on paper, so that one cannot help wondering sometimes, when hearing them sung in cultured accents to a piano accompaniment, whether it would not be better to let them die peacefully, a natural death, amid their appropriate setting - the roar of the sea and the moan of the wind in the shrouds-than to artificially prolong their life, like the mesmerized corpse in one of Poe's stories, to some day die a second and more horrid death, after jarring the nerves of our more cultured descendants.

There is hardly a duty on a sailing ship which has not its own Chanty to accompany it, from weighing anchor to furling the sails in the home port. The sailor's love for the Chanty, however, is not merely an asthetic one. The laborious work of hauling on ropes is made lighter and the pull of a few men more effective by the singing of the Chanty, which times the pull. A crowd of men pulling together in silence on perhaps a pitch-black night at sea, would more than likely pull just anyhow, one after the other, but the pull which comes with the chorus of the Chanty will contain the united efforts of the men, and as no man can be miserable for long when singing a jolly chorus, they serve the further purpose of cheering the men and keeping their minds off the little discomforts incidental to a "Life on the Rolling Wave."

The Chanty consists of one line of solo, which the Chanty-man standing at the head of the rope sings, and then the chorus, which the men sing as they pull.

The Chanty-man is a power on a sailing ship, 


\section{MEMORIES OF ANTARCTIC DAYS}

although $\mathrm{I}$ believe his position is not so clearly defined now as it used to be. He was elected by the hands forrard, and was expected to be an extempore poet, his ability to adapt the words of his Chanty to passing events being an important factor in deciding their choice.

The discipline at sea is of necessity a strict one. Complaints to those in power meet with little sympathy, and direct criticism of an officer would be rank insubordination, bringing with it a swift and unpleasant result. Grumbling, however, is an inherent part of a sailor's character, and the Chanty proves a useful safety-valve.

There is an unwritten law at sea that the words of a Chanty, so far as those aft are concerned, do not exist ; and many a sly hint to the officer of the watch is conveyed in the words of a Chanty.

On weighing anchor at the beginning of a voyage, the Chanty-man may sing:

We've a jolly good ship and a jolly good crew. Chorus: Away Rio.

A jolly good mate and a good skipper too.

Chorus: We're bound for Rio Grande,

every one starting off with a clean sheet, and the best of intentions, but many a ship which started on her voyage with this Chanty enters her home port with the crowd singing, in spite of the efforts of skipper and mate to suppress it :

$\mathrm{Oh}$, the work was hard and the voyage was long.

Chorus: Leave her, Johnny, leave her.

The food was bad and the gales were strong.

Chorus: It's time for us to leave her,

178 


\section{CHANTIES}

this doleful Chanty announcing to all who care to listen-and who could resist-the failing of those aft as officers, sailors or men; so that the Chanty and the Chanty-man is a power which it is not advisable for an officer to entirely ignore. Thinking a pull has gone on long enough, a Chanty-man will sing:

Chorus: Weigh-ay, blow the man down.

Oh, I fancied I heard the first mate say,

Another good pull, boys, then belay.

Chorus : Give us some time and we'll blow the man down, when he may take the hint and cry, "Belay," and he may not.

I suppose the voice of the average Chanty-man, judged by ordinary musical standards, is on a low level, so too would be the voice of the London hawker crying, "Sweet Lavender" ; place him in a drawingroom and the effect would be disastrous, but who is insensible to the charm of this cry, as the hawkers ply their trade in the London streets. It is a charm similar to this which the Chanties possess. The airs are simple, the words could certainly not be considered great poetry by any stretch of theimagination, and yet no one who has traversed the seas in a sailing ship will ever forget the pleasure of listening to sailors as they chantied up the topsails, hauled on the braces, or walked the capstan round. Officers who have forsaken sail for steamship may, as they sometimes do, pretend to despise the Chanties as songs, but in some corner of their hearts there is a warm corner kept for the Chanty, and all the pleasures and pains it recalls.

I was once a passenger on a liner, the captain of 


\section{MEMORIES OF ANTARCTIC DAYS}

which was a fine type of the men the sailing ship produced. We whiled away the tedious hours in the usual way. And as a contribution to the inevitable concert, I and one other contributed some Chanties, much to the professed astonishment of the captain, who expressed surprise that any one should consider these worthy to be classed as songs in the usually accepted sense of the word; he admitted they were "alright in their way, but they are not songs," and I gathered that he looked on them as having been left behind him with the sailing ship. But I think his feelings towards them were not so cold as he would have us believe, for next day, as we sat in the shadow of a boat yarning of old times and singing the despised Chanties, I noticed the Captain was never far away; pausing in his steady pacing up and down, he observed: "You've got that one wrong, my boy." "How does it go, then ?" said I. " Oh, my singing days are over," says he, but down he sat on the deck, giving us "Santa Anna," in true Chantyman fashion, to the astonishment of the deck Quartermaster, who promptly disappeared. Once having started, he gave us many quaint old Chanties, together with recollections of his sailing ship days, and the despised Chanty was by no means one of his least pleasant recollections. It was during his very early days at sea that he sailed on a ship which had a mixed crew of black and white men, the blacks working one side of the ship and the whites the other. But no sooner did the black crew begin to pull and haul, than his work was dropped and he was held as any child would be (for he was then little more 180 


\section{CHANTIES}

than a child in years), spellbound by the extraordinary antics of the blacks. Their naturally comic grimaces, their habit of keeping up a sort of jigstep as they chantied, and their typically negro tunes would usually end by doubling him up in fits of laughter. His enjoyment, however, was short-lived, as the mate's conception of discipline at sea made no allowance for a sense of humour. I think the enjoyment of the members of the crew, who witnessed the unbending of their captain, fully equalled ours.

The following is one of the negro Chanties:-

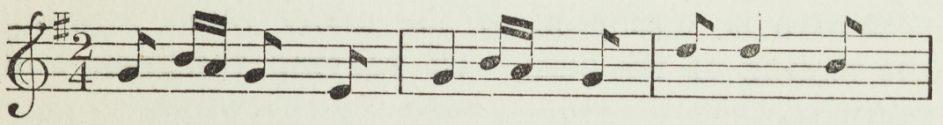

What did de blackbird sing to de crow ? Ma-hnd, how you

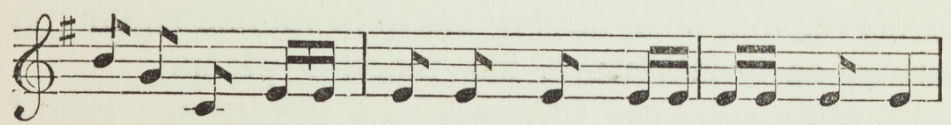

sthw-ing yo' tail, If we don't get sunshine, we're sure to get snow.

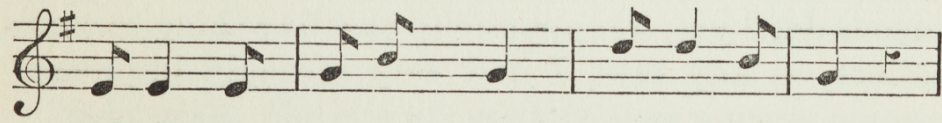

Mahnd, how you sthwing your tail. Hil - o, be - low;

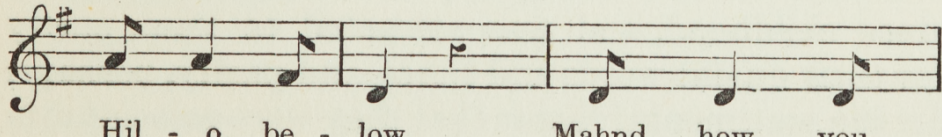

Hil - o, be - low. Mahnd, how you

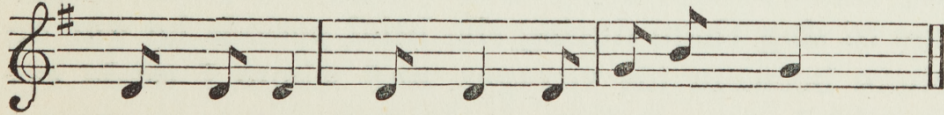

sthwing yo' tail, Mahnd, how yo' sthwing yo' tail. 


\section{MEMORIES OF ANTARCTIC DAYS}

Those whose experience of the sea has been confined to steamship will associate with the sea the steady throb of the ship's engines, and the swishswish of her bow-wash as she cleaves her way through the seas.

One has not been on a sailing ship long, however, before one becomes conscious of a faint but persistent musical hum in the air, which at first one is at a loss to account for. In storms this sound increases in volume, and one is aware that it is composed of many subtle harmonies which, as they swell and die away, leave an impression of some supernatural orchestra. Sooner or later one realizes that the orchestra is composed of the many ropes forming the rigging of the ship. Of varying thickness and tautness, they provide a harp for the winds to play upon. Such is the accompaniment the Chanties deserve, and, once having heard it, no one could tolerate, as a substitute, the jangling piano.

I have said the Chanties are dying out, and I believe they certainly are, but that they are by no means dead yet, but are still a very live thing to some sailors, at any rate, I had very strongly impressed on me during our voyage in the old Nimrod.

I have had a nodding acquaintance with Chanties since childhood, and was attracted to them partly for their quaint words and tunes, and partly, perhaps, for the sentimental reason that they were associated in my mind with a very young sailor cousin, who taught me to sing them during the brief periods he was on shore between his voyages, and whom I made my youthful hero mainly, I think, because he wore a 182 


\section{CHANTIES}

brass-bound cap very much on one side, had a knife in his belt, and generally a packet of sweets in one pocket and a Derringer pistol in the other, with which I once saw him shoot a black spider.

It was not until I joined the Nimrod that I saw them put to their proper use. Up till then they had been so many songs which sailors sang while working and, although I vaguely knew that each had appropriate tasks, yet I was unaware that this was a hard and fast condition in their use. We were hauling on the topsail halliards, I think, when I was called upon to strike up a Chanty. I started "We're homeward bound," an unfortunate choice to begin with, as we were leaving home as fast as we could. It certainly fitted after a fashion, though the pull was a slow one, but, to my surprise, the watch below turned out on deck, as I discovered later, to know why we were singing a capstan Chanty in mid ocean. It was a joke they never forgot, and they lost no opportunity of pulling my leg about it. Months afterwards I was introduced by one of them to a friend as "The chap who put a capstan Chanty to the topsail halliards."

The following chanties are some of our favourites in the Nimrod:- 


\section{MEMORIES OF ANTARCTIC DAYS}

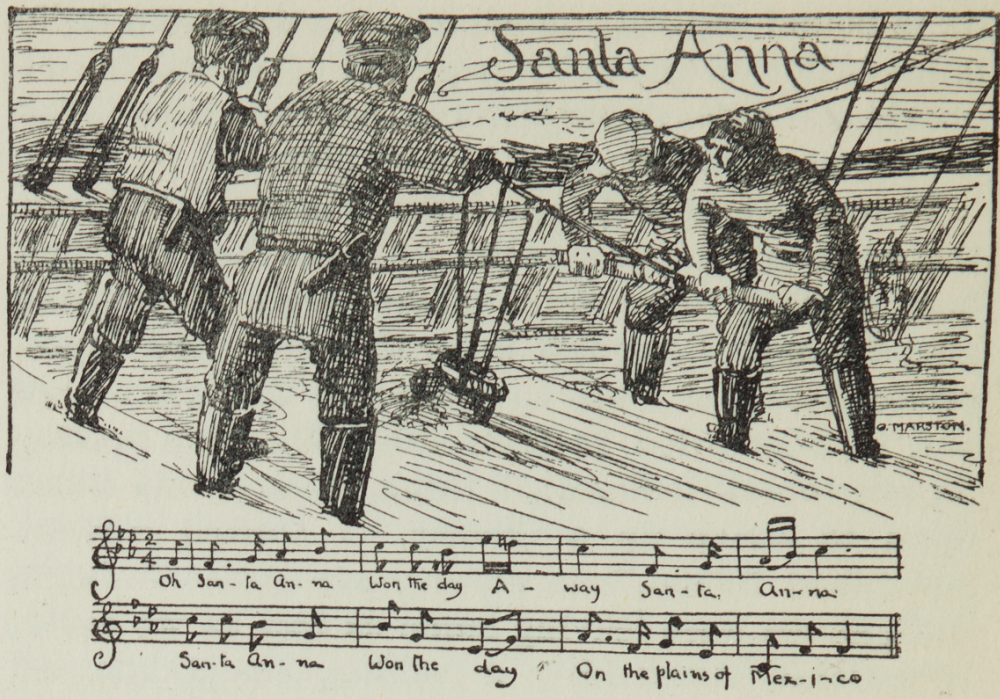

\section{SANTA ANNA}

Santa Anna fought for fame, Away, Santa Anna.

Santa Anna fought for fame, Along the plains of Mexico.

Oh, Santa Anna won the day,

Away, Santa Anna.

Santa Anna won the day,

Along the plains of Mexico.

Santa Anna's men were true, Away, Santa Anna.

They were the men for me and you,

Along the plains of Mexico. 


\section{CHANTIES}

\section{LEAVE HER, JOHNNIE}
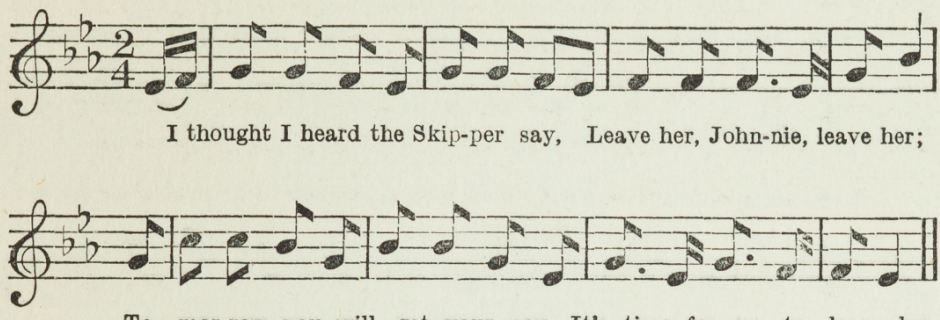

To-mor-row you will get your pay. It's time for us to leave her

The work was hard and the voyage was long. Chorus. Leave her, Johnnie, leave her.

The seas were high and the gales were strong. Chorus. It's time for us to leave her.

The food was bad and the wages low, Chorus. Leave her, Johnnie, leave her.

But now ashore again we'll go.

Chorus. It's time for us to leave her.

And may we never shipmates be.

Chorus. Leave her, Johnnie, leave her.

On a hard case ship such as she.

Chorus. It's time for us to leave her. 


\section{MEMORIES OF ANTARCTIC DAYS}

\section{DRUNKEN SAILOR}

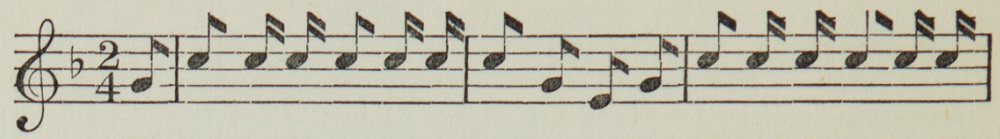

Oh, what shall we do with a drunk-en sail-or? What shall we do with a

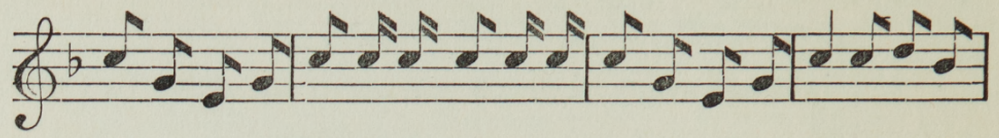

drunk-en sail - or? What shall we do with a drunk-en sail - or, Ear - ly in the

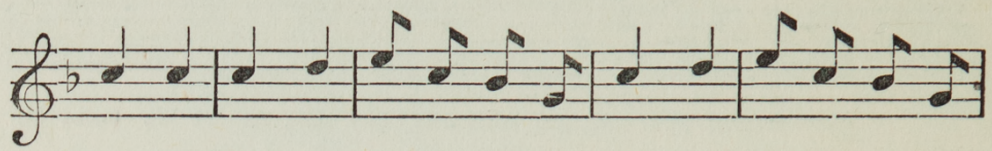

morn- ing? Weigh - aye, up she ris - es, Oh - aye, up she ris - es.

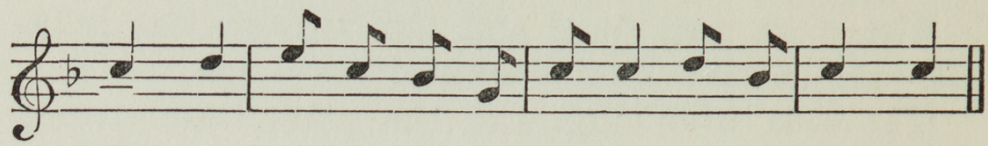

Weigh - aye, up she ris - es, Ear - ly in the morn - ing.

Hoist him up in a running bowline, Hoist him up in a running bowline, Hoist him up in a running bowline, Early in the morning.

Chorus. Weigh-aye, up she rises;

Oh-aye, up she rises; Weigh-aye, up she rises,

Early in the morning.

Shave his chin with a red-hot razor, Shave his chin with a red-hot razor, Shave his chin with a red-hot razor, Early in the morning.

Chorus. Weigh-aye, etc. 


\section{CHANTIES}

WHISKY, JOHNNIE

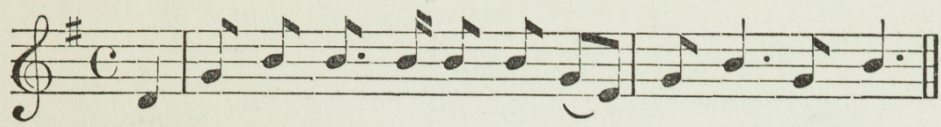

Oh, Whis-ky is the life of man, Whis-ky, John-nie:

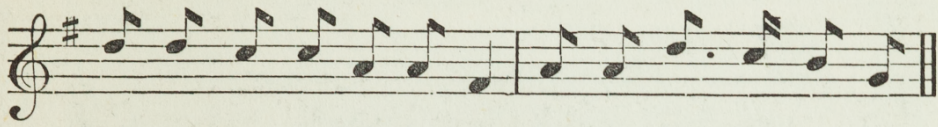

Whis-ky from an old tin can, Whis-ky for my John-nie.

Whisky made the skipper say,

Whisky, Johnnie.

Another pull and then belay.

Whisky for my Johnnie.

Whisky killed my poor old dad,

Whisky, Johnnie,

Whisky drove my brother mad.

Whisky for my Johnnie.

If Whisky was a river and I was a duck, Whisky, Johnnie.

I'd dive to the bottom and I'd never come up.

Whisky for my Johnnie.

Whisky always makes me sad, Whisky, Johnnie.

Whenever there's none of it to be had.

Whisky for my Johnnie.

Whisky stole my brains away.

Whisky, Johnnie,

The boatswain pipes, so I'll belay.

Whisky for my Johnnie. 


\section{MEMORIES OF ANTARCTIC DAYS}

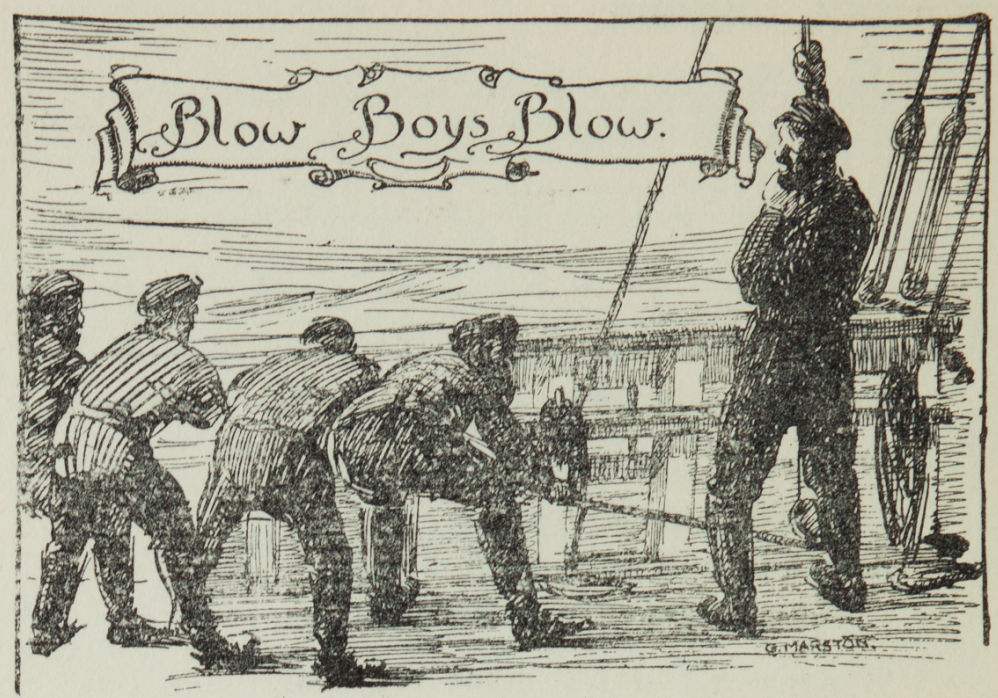

\section{YANKEE SHIP}

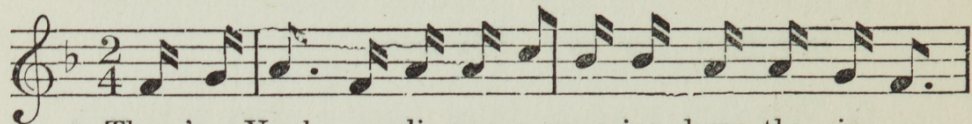

There's a Yank - ee clip-per a-com-ing down the riv - er,

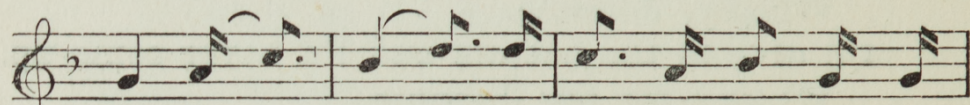

e Blow, boys, blow. A Yan - kee clip - per a -

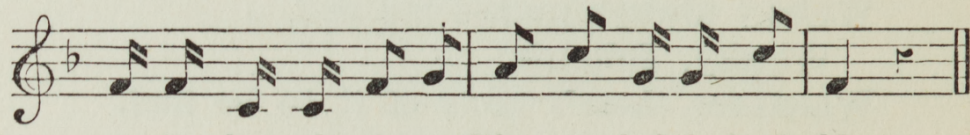

com-ing down the riv-er, Blow, my bul-ly boys, blow.

And how do you know she's a Yankee clipper? Chorus. Blow, boys, blow.

And how do you know she's a Yankee clipper? Chorus. Blow, my bully boys, blow. 


\section{CHANTIES}

The Stars and Stripes they stream behind her. Blow, boys, blow.

The Stars and Stripes they stream behind her.

Blow, my bully boys, blow.

And who do you think was skipper of her?

Blow, boys, blow.

Old preaching Sam, the noted scoffer.

Blow, my bully boys, blow.

The mate was Joe, the ' $F$ 'isco digger.

Blow, boys, blow.

And the boatswain was a big buck nigger.

Blow, my bully boys, blow.

And what do you think they had for dinner?

Blow, boys, blow.

And what do you think they had for dinner ?

Blow, my bully boys, blow.

'Twas the larboard side of an old so'wester.

Blow, boys, blow.

'Twas the larboard side of an old so'wester.

Blow, my bully boys, blow.

They sailed away for London city.

Blow, boys, blow.

And never got there, more's the pity.

Blow, my bully boys, blow.

Blow to-day and blow to-morrow.

Blow, boys, blow.

And blow for that old ship in sorrow.

Blow, my bully boys, blow. 


\section{MEMORIES OF ANTARCTIC DAYS}

\section{BLOW THE MAN DOWN}

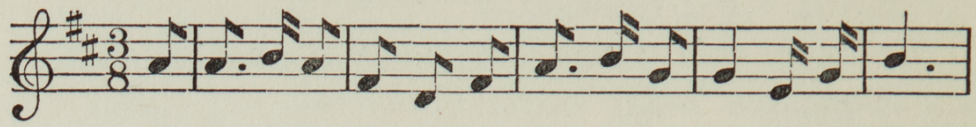

As I was a - roll-ing down Par-a-dise Street To me Weigh-

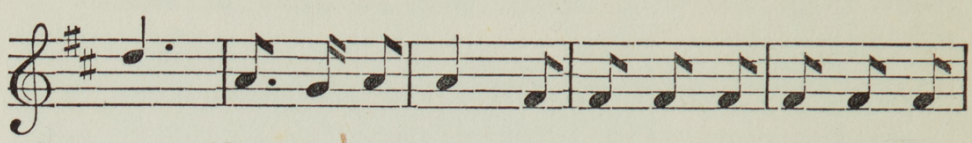
aye, blow the man down. A pret-ty young mai-den I

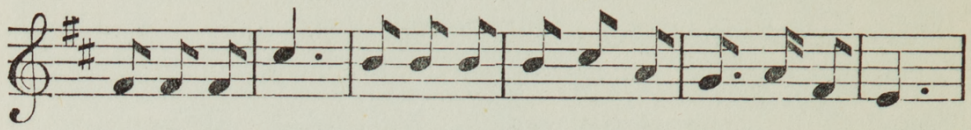
chanced for to meet. Give us some time and we'll blow the man down.

She was round in the counter and bluff in the bows.

Chorus. To me, Weigh-aye, blow the man down. She was round in the counter and bluff in the bows.

Chorus. Give us some time and we'll blow the man down.

$\mathrm{Oh}$, where are you going to, my pretty maid ? Chorus. To me, Weigh-aye, blow the man down. $\mathrm{Oh}$, where are you going to, my pretty maid? Chorus. Give us some time and we'll blow the man down.

I'm going a-milking, kind sir, she said. Chorus. To me, Weigh-aye, blow the man down. I'm going a-milking, kind sir, she said. Chorus. Give us some time and we'll blow the man down. 


\section{CHANTIES}

\section{SHENANDOAH}

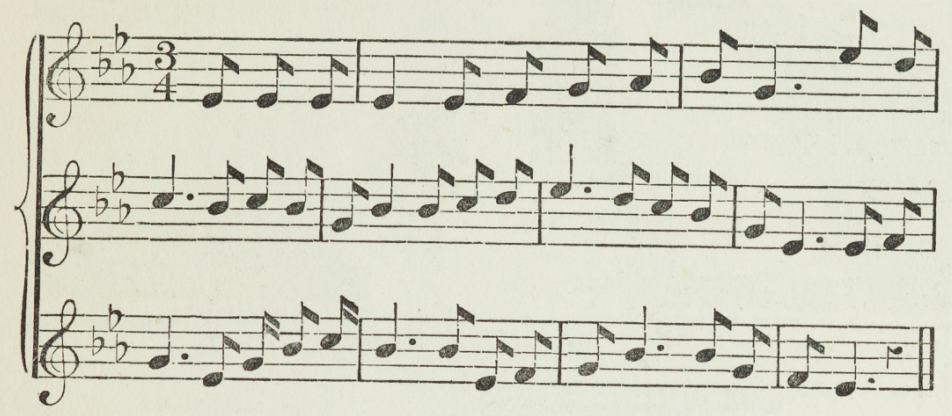

Oh, Shenandoah, I love your daughter.

Away, my rolling river.

Shenandoah, I love your daughter,

Away, we're bound away across the wide Missouri.

Polly's girl just took my fancy.

Away, my rolling river.

She's clipper built, her name is Nancy.

Away, we're bound away across the wide Missouri.

I take her coral beads and laces.

Away, my rolling river.

I love to call her queen of faces,

Away, we're bound away across the wide Missouri.

She lives alone in London City.

Away, my rolling river.

Perhaps you'll think it's more the pity.

Away, we're bound away across the wide Missouri. 


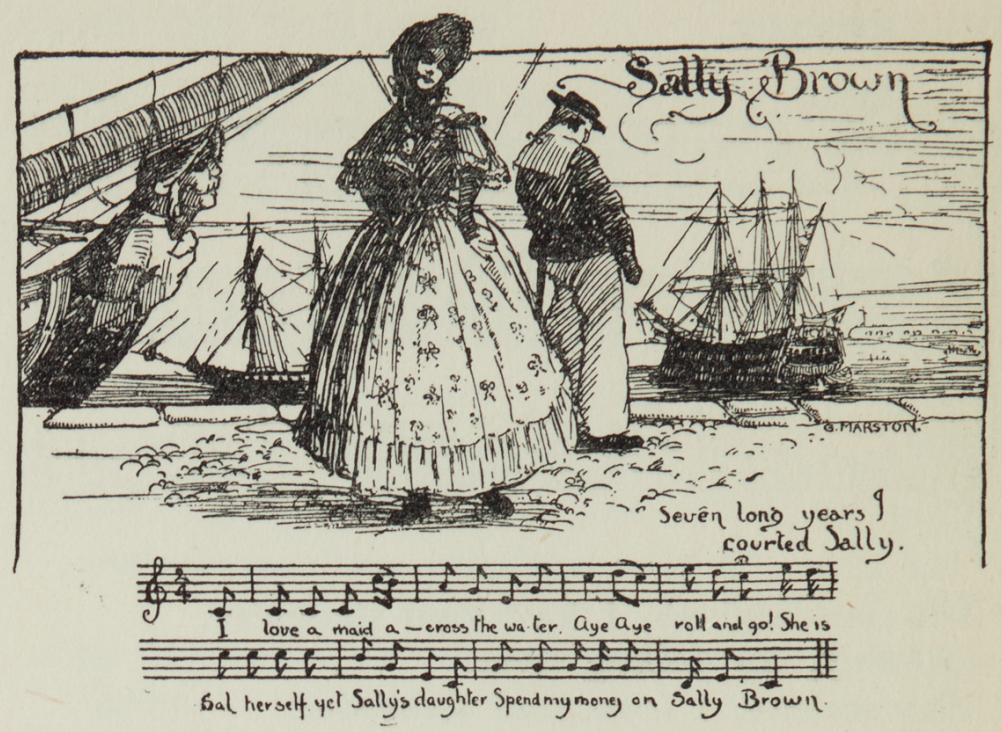

Seven long years I courted Sally. Aye, aye, roll and go.

She called me boy and Dilly Dally. Spend my money on Sally Brown.

Seven long years and she wouldn't marry. Aye, aye, roll and go.

Until I no longer cared to tarry. Spend my money on Sally Brown.

So I courted Sal, her only daughter. Aye, aye, roll and go. And it is for her I sail upon the water. Spend my money on Sally Brown. 192 
THE MERMAN
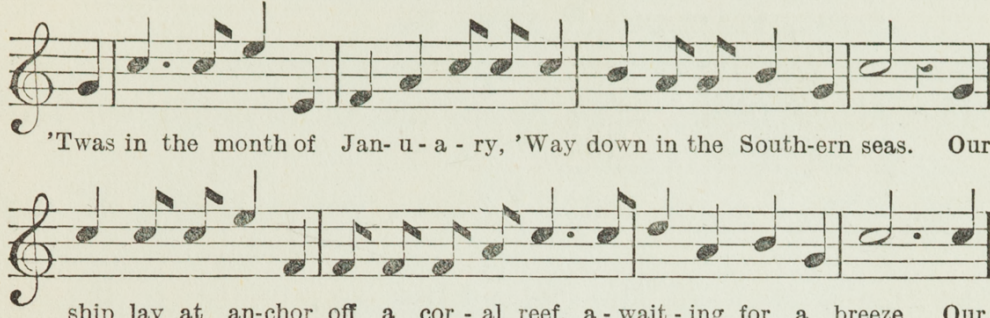

ship lay at an-chor off a cor-al reef, a-wait-ing for a breeze. Our

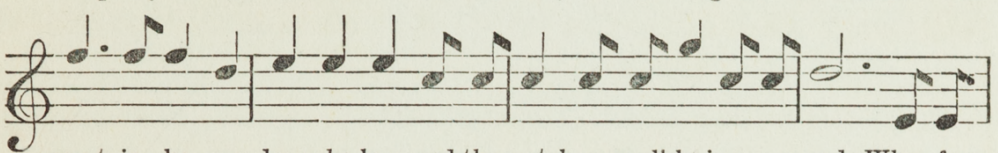

cap-tain he was down be-low, and the watch were all ly-ing a-round, When from

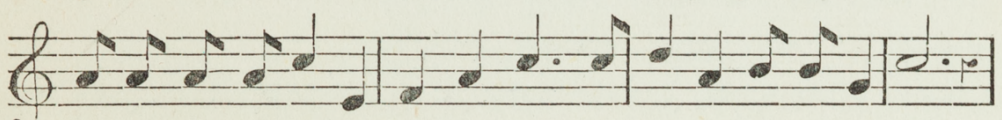

un-der-neath our bows we heard a sound, and then a reg - u - lar shout,

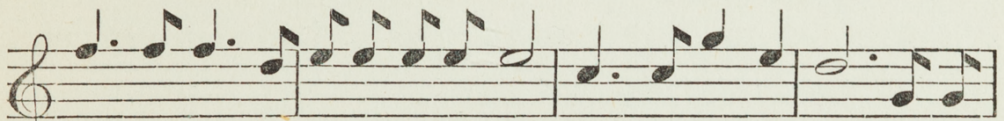

Heave a-way my jol-ly, jol-ly boys, Heave a-way, cried he, for you've

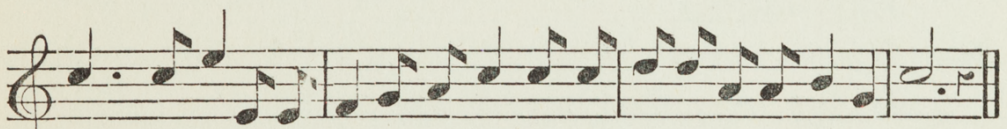

dropped your an-chor in front of my door, At the bot-tom of the deep blue sea.

"Man overboard," the watch cried out, and for'ard we all ran,

And there, hanging on to our best bower chain, was a jolly old merman.

His eyes were blue, his hair was green, his head was as big as three,

And a long green tail, which he sat upon, kept wagging down in the sea.

Chorus. Heave away, etc. 


\section{MEMORIES OF ANTARCTIC DAYS}

"Hullo," says our first mate as bold as brass, "what cheer, shipmate," says he.

"I want for to ask your Capitain a favour to grant we. The other night with some other mermen we had a bit of a spree,

But when I came home I found your anchor at my door,

At the bottom of the deep blue sea.

My wife and children can't get out, and the worst of it is, you see,

Oh, you should hear the way they shout, blaming it all on to me."

Chorus. So heave away, etc.

Our Captain he came for'ard then and looked in the waters blue.

"Come tell me, my merman, as quickly as you can, what I can do for you.

Your face is like a sailor bold and you speak like an Englishman,

But I never met a scale, from a winkle to a whale in the sea, that speak to me."

Chorus. So heave, heave away, etc.

"Some time ago, from the ship Hero I was washed overboard in a gale,

And wandering about, where the seaweeds grow, I met a maid with a tail.

She saved my life, so I made her my wife, and my legs changed instantly,

And now we live as happy as can be,

At the bottom of the deep blue sea.

Chorus. So heave away, etc. 


\section{CHANTIES}

\section{RIO GRANDE}

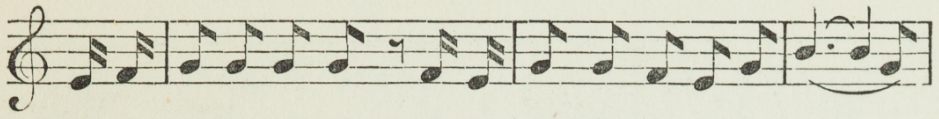

Oh, the an-chor is weighed, and the sails they are set, A - way . . .
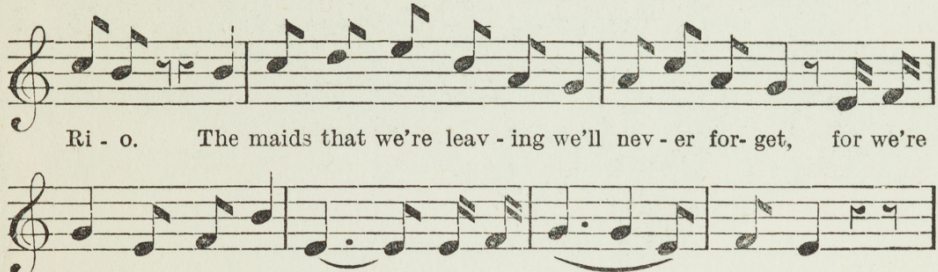

bound to Ri - o Grande, And a - way - - Ri - o,
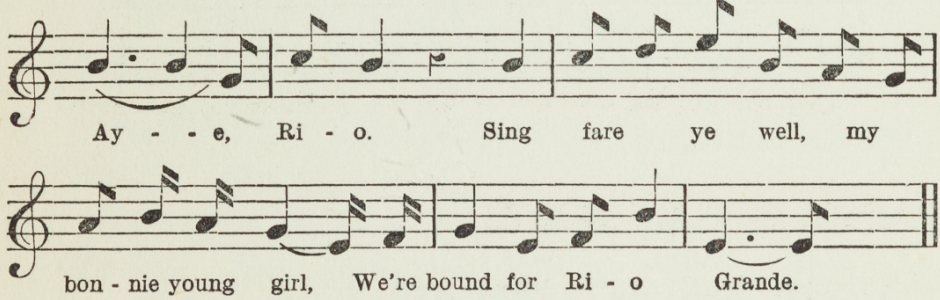

We've a jolly good ship and a jolly good crew. Away Rio.

A jolly good mate and a good skipper, too.

We're bound for Rio Grande.

We'll sing as we heave to the maidens we leave. Away Rio.

You know at this parting how sadly we grieve,

We're bound for Rio Grande.

The chain's up and down now the boatswain did say, Away Rio.

Heave up to the hawse pipe, the anchor's a-weigh; We're bound for Rio Grande. 


\section{MEMORIES OF ANTARCTIC DAYS}

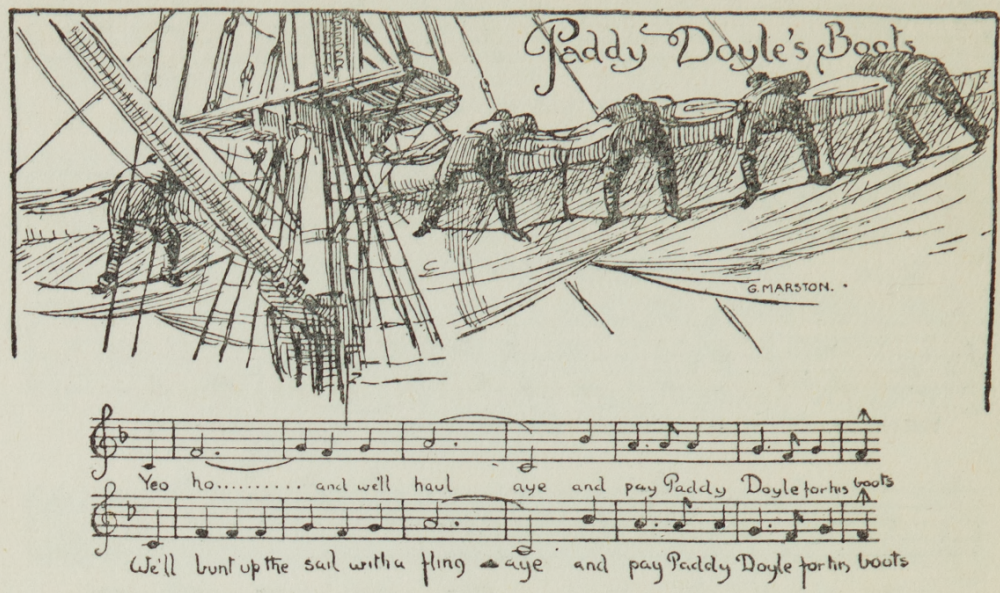

\section{PADDY DOYLE'S BOOTS}

Yeo-ho, and we'll haul aye, And pay Paddy Doyle for his boots. We'll tauten the bunt and we'll furl ayeAnd pay Paddy Doyle for his boots.

Yeo-ho, and we'll sing aye, And pay Paddy Doyle for his boots. We'll bunt up the sail with a fling ayeAnd pay Paddy Doyle for his boots. 


\section{CHANTIES}

STORM ALONG

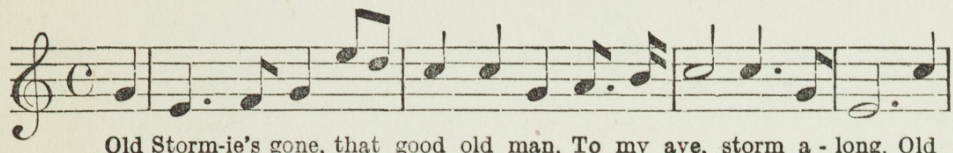

Old Storm-ie's gone, that good old man, To my aye, storm a - long. Old

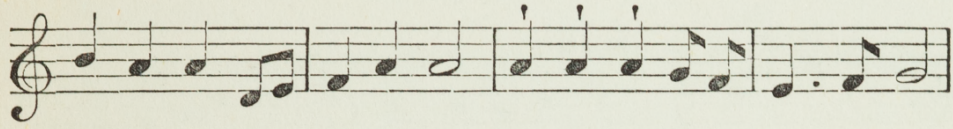

Storm-ie's gone, that good old man. Aye, aye, aye, Mis-ter Storm a-long.

We dug his grave with a silver spade. Chorus. To my, etc.

His shroud of finest silk was made.

Chorus. Aye, aye, ete.

We lowered him down with a golden chain.

Chorus. To my, etc.

Our eyes all dim with more than rain.

Chorus. Aye, aye, etc.

Old Storm has heard the Angels call.

Chorus. To my, etc.

So sing his dirge, now, one and all.

Chorus. Aye, aye, etc.

He was a skipper bold and true.

Chorus. To my, ete.

A good old skipper to his crew.

Chorus. Aye, aye, ete.

He's moored at last and furled his sail.

Chorus. To my, etc.

No danger now from storms or gales.

Chorus. Aye, aye, etc. 


\section{MEMORIES OF ANTARCTIC DAYS}

\section{SPANISH LADIES}
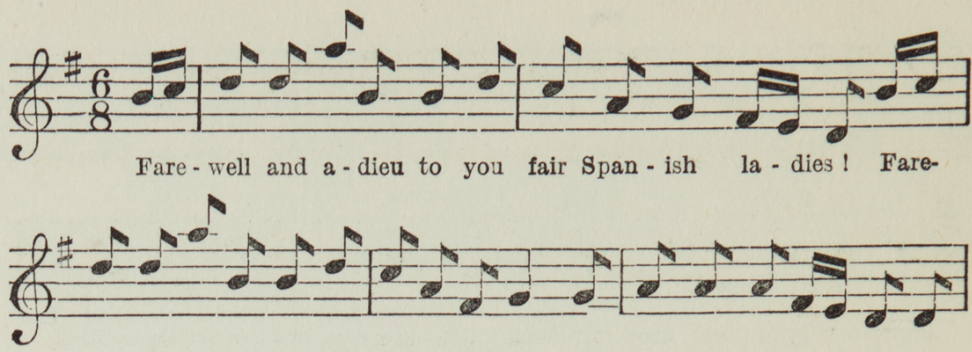

well and a-dieu to you la-dies of Spain! For we've re-ceived or - ders to

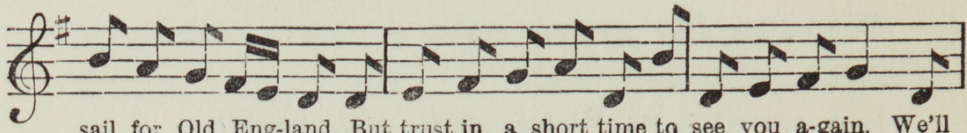

sail for Old Eng-land, But trust in a short time ta see you a-gain. We'll
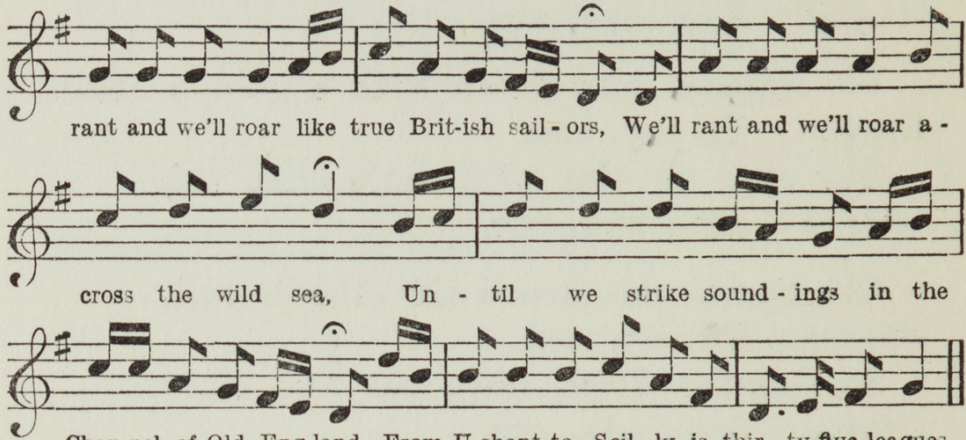

Chan-nel of Old Eng-land. From U-shant to Scil-ly is thir-ty-flve leagues.

(Shouted: Heave and lift her.)

We hove our ship to, with the wind at sou'-west, boys;

We hove our ship to, for to strike soundings clear. Then filled up our main topsail and bore right away, boys.

And straight up the Channel our course we did steer.

Chorus. We'll rant and we'll roar, ete. 


\section{CHANTIES}

The first land we made was a point called the Deadman.

Next Ram's Head off Plymouth, Start, Portland and Wight.

We sailed then by Beachy, by Fairlee and Dung'ness,

Then bore straight away for the South Foreland light.

Chorus. We'll rant and we'll roar, ete.

The signal was made for the grand fleet to anchor.

We clewed up our topsails, stuck out tacks and sheets.

We stood by our stoppers, we brailed in our spanker,

And anchored ahead of the noblest of fleets.

Chorus. We'll rant and we'll roar, ete.

Then let every man here toss off a full bumper.

Then let every man here toss off his full bowl.

For we will be jolly and drown melancholy,

With a health to each jovial, true-hearted soul.

Chorus. We'll rant and we'll roar, etc. 
Butler \& Tanner, The Selwood Printing Works, Frome, and London. 

Protaretic

508.985

M 982 


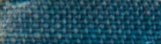

of

Fop.

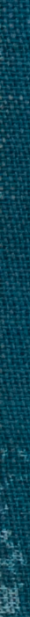

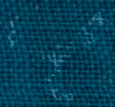

